\title{
Articles
}

\section{Federal Sentencing in the Wake of Guidelines:} Unacceptable Limits on the Discretion

\section{of Sentencers}

\author{
Daniel J. Freed $\dagger$
}

\section{CONTENTS}

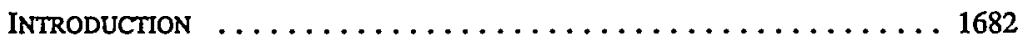

I. A REFORM UNDER FIRE $\ldots \ldots \ldots \ldots \ldots \ldots \ldots \ldots \ldots \ldots \ldots \ldots$

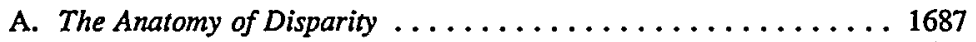

B. The Statutory Scheme ..................... 1689

C. Questions for Study . . . . . . . . . . . . . . . . . 1691

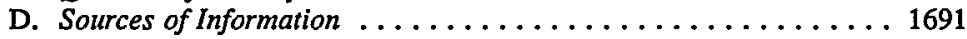

II. The Structure of Guideline Decisionmaking $\ldots \ldots \ldots \ldots \ldots 1693$

A. Policymaking . ...................... 1693

B. Rulemaking .......................... 1694

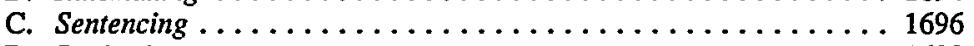

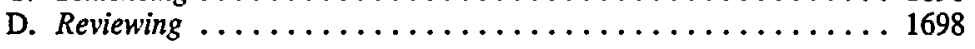

† Clinical Professor of Law and Its Administration, and Director, Criminal Sentencing Program, Yale Law School; Editor, Federal Sentencing Reporter.

This Article is informed by nearly two decades of exploring discretionary sentencing and its reform, in state and federal courts, in collaboration with an extraordinary group of students, judges, and colleagues. These ventures, illustrated in note 7 , infra, would not have been possible without the educational vision and generous support of The Daniel and Florence Guggenheim Foundation, 1972-1987, and The Edna McConnell Clark Foundation since 1988. I am especially grateful for wise criticisms and suggestions on earlier drafts by Milton Heumann, Morris Lasker, Pierre Leval, Marc Miller, Dale Parent, Aaron Rappaport, Michael Tonry, and Ronald Weich. My most enduring debt is to Judith Freed, for her remarkable insights and caring contributions throughout the project. 
III. The COMMISSION at Work $\ldots \ldots \ldots \ldots \ldots \ldots \ldots \ldots \ldots \ldots \ldots$

A. Statutory Instructions $\ldots \ldots \ldots \ldots \ldots \ldots \ldots \ldots \ldots \ldots 170 \ldots \ldots$

B. Policy Choices ......................... 1703

C. Guidelines in Action ...................... 1703

1. Disproportionality ....................... 1704

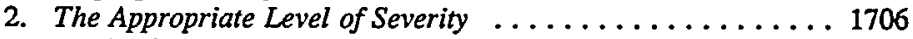

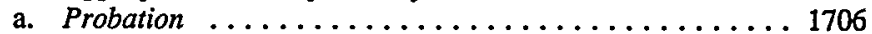

b. Purposes ....................... 1708

c. Substantial Assistance ................... 1710

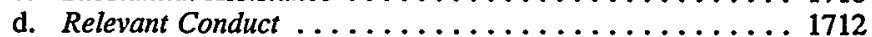

3. Offender Characteristics: "Not Ordinarily Relevant" ...... 1715

IV. DistRICT COURT SENTENCING: RIGID GUIDELINES IN A

DisCRETIONARY PROCESS . . . . . . . . . . . . . . . 1718

A. Judicial Reactions to the Commission .............. 1719

B. Process Responses by Four Sentencers . . . . . . . . . 1720

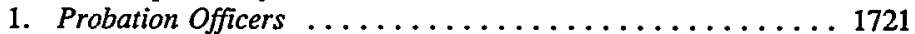

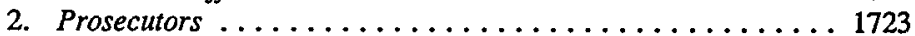

3. Defense Attorneys .......................... 1724

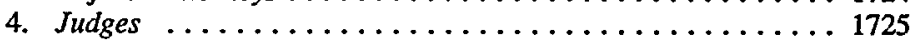

V. Guideline Validity: The Neglected Appellate Issue $\ldots \ldots \ldots 1727$

A. The Gap Between Circuit Court and District Court Perspectives . 1728

B. The Gap Between Statutory Principles and Circuit Court Case Law 1730

1. Not Distinguishing Policy Statements from Guidelines ..... 1731

2. Not Testing the "Adequacy" of Guideline Consideration ..... 1733

3. Not Implementing the Instruction to "Reduce Unwarranted Disparity" . . . . . . . . . . . . . . . . . . 1737

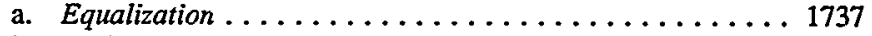

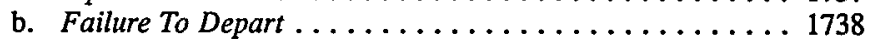

c. Hidden Disparities . . . . . . . . . . . . . 1739

d. Illegal Evidence ...................... 1739

VI. RETHINKING THE GUIDELINES $\ldots \ldots \ldots \ldots \ldots \ldots \ldots \ldots \ldots \ldots$

A. What Went Wrong? ..................... 1741

1. The Sentencing Commission ................ 1741

a. Membership ...................... 1741

b. Research ....................... 1743

c. Mixed Messages About Departures ............. 1744

2. District Courts ...................... 1745

3. Courts of Appeals ...................... 1747

B. Where to Next? ...................... 1747

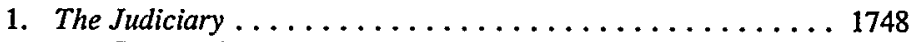

a. Courts of Appeals . . . . . . . . . . . . . . . 1748

b. District Courts . . . . . . . . . . . . . . . . . . . 1749

c. Judicial Conference of the United States .......... 1750

2. The Sentencing Commission ................... 1750

3. The Congress .......................... 1751

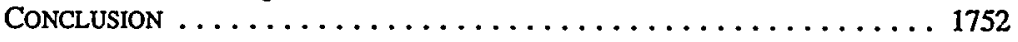

\section{INTRODUCTION}

The federal sentencing process has long been characterized by dynamic relationships between judges and others who exercise powerful discretion in shaping criminal sanctions for convicted offenders. The implementation of the 
federal sentencing guidelines ${ }^{1}$ has altered these relationships in ways not anticipated by Congress or the United States Sentencing Commission (Commission), and not recognized by many judges.

Because of these altered interactions, the guidelines system initiated in 1987 simultaneously proceeds on two different levels: (1) the level of formal, visible adherence to, or open departure from, guideline prescriptions in the trial courts, followed by review in the courts of appeals; and (2) the level of informal noncompliance with the new system-practices that are eluding scrutiny by courts of appeals and are in fact reacting to appellate rejections of reasonable departures from unreasonable guidelines. Increasingly, the second, underground level of sentencing seems to be displacing the first, visible level. ${ }^{2}$

Imposing a new legal structure on a process traditionally governed by discretion is an important and difficult task. This Article examines the hypothesis that the quality and acceptability of the guidance, rather than the fact of guidelines, spells the difference between respected reform and rigid failure. To achieve the requisite level of quality, a guidance system must contemplate multiple levels of discretion. It must leave ample room for departures from the guideline range so that judges can accommodate cases of greater and lesser seriousness. It must be developed by an institution that understands the complexity of criminal sentencing, that appreciates the wisdom, integrity and sense of justice that animates experienced judges, and that earns the respect of judges and practitioners.

History teaches that statutorily imposed mandatory sentences are unjust and often nullified by juries, judges, and prosecutors. ${ }^{3}$ The imposition of "mandato-

1. See U.S. Sentencing Comm'N, Federal Sentencing Guidelines Manual (1992) [hereinafter U.S.S.G.].

2. The Commission acknowledges that informal noncompliance with the guidelines is a problem. See U.S. SENTENCING COMM'N, THE FEDERAL SENTENCING GUIDELINES: A REPORT ON THE OPERATION OF THE GUIDELINES SYSTEM AND SHORT-TERM IMPACTS ON DISPARITY IN SENTENCING, USE OF INCARCERATION, AND PROSECUTORIAL DISCRETION AND PLEA BARGAINING 419-20 (1991) [hereinafter U.S.S.C. IMPACT REPORT]. A recent study authorized by the Commission, id. at 393, and conducted by Ilene Nagel, a Commissioner, and Stephen Schulhofer, acknowledges that circumvention is "an important obstacle to the success of the guidelines effort." Iene H. Nagel \& Stephen J. Schulhofer, A Tale of Three Cities: An Empirical Study of Charging and Bargaining Practices under the Federal Sentencing Guidelines, 66 S. CAL. L. REV. (forthcoming Nov. 1992) (manuscript at 82-17, on file with author). They note that "[t] he principal problem with guideline circumvention is that circumvention, unlike overt downward departure, is hidden and unsystematic. It occurs in a context that prevents oversight and obscures accountability." Id. Professor Schulhofer, in another forthcoming article based in part on the same study, states that preliminary data "suggests that evasion of the proper guideline sentence may occur in 20-35\% of all guilty plea cases." Stephen J. Schulhofer, Assessing the Federal Sentencing Process: The Problem is Uniformity, Not Disparity, 29 AM. CRM. L. REv. (forthcoming May 1992) (manuscript at 17, on file with author). Because of the elimination of the judge's power to offset "plea-related disparity" and of parole, he says that "there is probably a great deal more disparity than pre-guidelines in the 20-35\% of the cases affected by manipulation." Id. at 18; see also discussion infra Part IV.B.

3. Over the centuries, historians have recounted numerous instances in which judges, juries, or prosecutors nullified an oppressive law or evaded its formal strictures to avoid imposing disproportionate penalties on individual lawbreakers. See JEROME HALL, THEFT, LAW AND SOCIETY 63 (1935); Douglas Hay, Property, Authority and the Criminal Law, in ALBION'S FATAL TREE: CRIME AND SOCIETY IN EIGHTEENTHCENTURY ENGLAND 17 (Douglas Hay et al. eds., 1975); Milton Heumann \& Lance Cassak, Not-So-Blissful 
ry guidelines" by the new federal administrative agency is now spawning similar lessons. ${ }^{4}$ The Commission's tightening of "loopholes," combined with strict enforcement by courts of appeals hostile to departures, has increased the level of noncompliance in trial courts. Discretionary actors, including judges, prosecutors, defense attorneys, and probation officers, find themselves torn between allegiance to rigid rules and an urge to do justice in individual cases.

Unless the Commission and the appellate courts heed these lessons, the guidelines system will soon lose all credibility. ${ }^{5}$ In that event, some new vehicle of sentencing reform, tied more closely to the judiciary and a consultative process for identifying a common law of sentencing, may be needed. ${ }^{6}$

This Article examines the guidelines from the vantage point of a close and continuous observer. ${ }^{7}$ Part I briefly traces the evolution of the current system.

Ignorance: Informing Jurors About Punishment in Mandatory Sentencing Cases, 20 AM. CRM. L. REV. 343 (1983). Some enforced the penalties without exception, out of a sense of paramount duty to the written law. Others acted in the belief that the prevailing penalty structure was necessary and just. Still others imposed severe penalties, expecting that their inappropriateness would cause reviewing authorities to grant clemency before the sentences were actually carried out. See, e.g., Jon O. Newman, Foreword to William J. Genego et al., Parole Release Decisionmaking and the Sentencing Process, 84 YALE L.J. 810, 812 (1975); Hay, supra, at $40,56-58$.

In some jurisdictions, juries rather than judges bear primary responsibility for sentencing. Juries almost always make the decision to pass a capital sentence. In addition, juries, by acquitting a defendant against the evidence, may nullify a sentence. Heumann \& Cassak, supra, at 352-57; HALL, supra, at 126-30 (noting widespread practice of 18 th-century juries to return fictitious verdicts). The seven states that give the jury a role in non-capital sentencing are Arkansas, Kentucky, Missouri, Oklahoma, Tennessee, Texas, and Virginia. See ARK. CODE ANN. § 5-4-103 (Michie 1987); KY. REV. STAT. ANN. §§ 532.025, 532.055, 532.070 (Michie/Bobbs-Merrill 1990); Mo. ANN. STAT. $\$ 557.036$ (Vernon 1979); OKLA. STAT. ANN. tit. $22, \S 928$ (West 1985); TENN. CODE ANN. \$§ 40-20-104 to 40-20-107 (1990); TEX. CRIM. CODE ANN. § 37.07 (West 1981); VA. CODE ANN. $§ 19.2-295$ (Michie 1990).

4. This is the Commission's own characterization of its guidelines. U.S. SENTENCING COMM'N, SPECIAL REPORT TO THE CONGRESS: MANDATORY MINIMUM PENALTIES IN THE FEDERAL CRIMINAL JUSTICE SYSTEM, at i (1991) [hereinafter MANDATORY MINIMUM PENALTIES REPORT]. The Commission prescribed "mandatory prison sentences" in lieu of probation in its initial 1987 guidelines. See U.S.S.G., supra note 1, app. c, amend. 307, at 134. "The Commission's solution to this problem has been to write guidelines that classify as 'serious' (and therefore subject to mandatory prison sentences) many offenses for which probation is now frequently given." The Commission deleted the parenthetical reference to "mandatory prison sentences" without explanation in 1990. Id. at 138.

5. The Commission asked 415 judges about "unwarranted sentencing disparity under the sentencing guideline system compared to the pre-guideline sentencing system." Sixty-four percent of the judges who responded thought the system was worse off or no better than before the guidelines. Only $36 \%$ of those who expressed an opinion thought disparity had decreased. U.S.S.C. IMPACT REPORT, supra note 2, at 103 tbl. 25 .

6. It is difficult to determine whether the evolving guidelines are "working well." See Michael Tonry, Are the U.S. Sentencing Commission's Guidelines "Working Well"?, 2 FED. SENTENCING REP. 122 (1989) (asserting that current data do not indicate how well the sentencing system is working). If the guidelines are basically on target, critics should be patient and work to improve them through the amendment process. See 28 U.S.C. § 994(0) (1988) (stating that Commission "periodically shall review and revise, in consideration of comments and data coming to its attention, the guidelines promulgated pursuant to the provisions of this section"). If the situation is less optimistic, sponsors and supporters might be well advised to reconsider.

7. Yale's involvement with sentencing reform dates back to 1974 , when a workshop, sponsored by The Daniel and Florence Guggenheim Program in Criminal Justice, was convened to examine Judge Frankel's proposal for a federal sentencing commission, MARVIN E. FRANKEL, CRIMINAL SENTENCES: LAW WrTHOUT ORDER 118-24 (1972), against the background of an ongoing law journal study of the relationship between indeterminate sentencing and parole guidelines. See William J. Genego et al., Parole Release 
Part II describes the four-level guidelines system: policymaking, rulemaking, sentencing, and reviewing. Part III examines the rulemakers, Congress and the Commission, concentrating on how the Commission has responded to its statutory charter. Part IV discusses the sentencers: judges, probation officers, defense attorneys, and prosecutors. Part V deals with the reviewers: the district courts and the courts of appeals. It looks especially at the interplay between the district court sentencing process and guideline enforcement by the appellate bench.

Part VI considers the panorama of problems and reflects on why the federal sentencing guidelines are not succeeding. It then suggests corrective action that might be taken by the judiciary, the Commission, and Congress.

\section{A REFORM UNDER FIRE}

For most of the last century, our criminal justice system has relied on indeterminate sentencing. In the last two decades, however, growing dissatisfaction with the disparity and uncertainty of indeterminate sentencing has led to broad support for the idea of structured sentencing to reduce unwarranted disparity. The Sentencing Reform Act of $1984^{8}$ (SRA) symbolized the emerging consensus in the federal system and many states. ${ }^{9}$

Over their first five years, the U.S. Sentencing Commission's guidelines have provoked dismay and evasion in the federal courts and the bar. ${ }^{10}$ During

Decisionmaking and the Sentencing, 84 YALE L.J. 810 (1975). The workshop produced draft legislation for a U.S. Commission on Sentencing, which is set forth and explained in PIERCE O'DONNELL ET AL., TOWARD A JUST AND EFFECTIVE SENTENCING SYSTEM: AGENDA FOR LEGISLATIVE REFORM 33-134 (1977). "The findings of the workshop constituted the foundation of S. 2699, a bill I introduced in the 94th Congress." Edward M. Kennedy, Foreword to id. at ix.

In 1984, Yale inaugurated a series of Guggenheim Program collaborative workshops for law students and sentencing judges to examine the principles on which judges exercise discretion in formulating sentences in state and federal courts, and the impact of sentencing commissions on discretion, disparity, prison populations, and rationality in sentencing. Following the establishment of the U.S. Sentencing Commission, five of the original seven members of the Commission participated in these workshops. Since 1988, Yale's sentencing workshops have continued, with the support of the Edna McConnell Clark Foundation, to examine discretion, disparity, and issues relating to intermediate punishment, in collaboration with state judges and prosecutors from Alabama and Delaware.

A work that grew out of the Yale program is DALE G. PARENT, STRUCTURING CRIMINAL SENTENCES: THE EVOLUTION OF MINNESOTA's SENTENCING GUIDELINES (1988). Another is the Federal Sentencing Reporter, launched in June 1988 under the sponsorship of the Vera Institute of Justice, edited by Daniel J. Freed and Marc Miller, and published bimonthly by the University of Califomia Press.

8. Pub. L. No. 98-473, 98 Stat. 1987 (1984) (codified as amended at 18 U.S.C. $\$ \S 3551-3559,3561$ $3566,3571-3574,3581-3586$ (1988), and 28 U.S.C. $\$ \S 991-998$ (1988)).

9. Various studies, reports, and scholarship highlighted the deficiencies of the pre-guidelines process. See, e.g., S. REP. No. 225, 98th Cong., 2d Sess. $37-50$ (1984), reprinted in 1984 U.S.C.C.A.N. 3182, 322033; AMERICAN FRIENDS SERVICE COMM., STRUGGLE FOR JUSTICE: A REPORT ON CRIME AND PUNISHMENT IN AMERICA (1971); FRANKEL, supra note 7; TWENTIETH CENTURY FUND TASK FORCE ON CRIMINAL SENTENCING, FAIR AND CERTAIN PUNSHMENT (1976); ANDREW VON HIRSCH, DOING JUSTICE: THE CHOICE OF PUNISHMENTS (1976).

10. A number of federal judges, scholars, and others have criticized the guidelines. See FEDERAL COURTS STUDY COMM., REPORT OF THE FEDERAL COURTS STUDY COMMITTEE 135-43 (1990) [hereinafter FCSC REPORT]; Judge Edward R. Becker, 3d Cir., Statement to the U.S. Sentencing Comm'n on behalf 
the same period, Congress' proliferation of mandatory minimum penalty statutes ${ }^{11}$ has elicited protest from the Commission as well as the courts. The U.S. courts of appeals, while also opposing mandatory penalty statutes, ${ }^{12}$ have themselves come under fire for imposing needlessly rigid interpretations of the guidelines on the district courts. ${ }^{13}$

Federal district court judges are torn as to how to respond to this spate of restrictions on their sentencing discretion. ${ }^{14}$ There is a powerful sense that the guidelines dictate unjust sentences in too many cases, but reactions by individual judges vary widely. Many judges are conforming to the guidelines with a deep sense of distress: they believe Congress, not the courts, should remedy policy problems created by the Commission. Other judges are finding or acquiescing in alternative routes to justice in sentencing: some are choosing to risk reversal on appeal by "departing" upward or downward from the guideline

of the Judicial Conference Comm. on Criminal Law and Probation Admin. (Mar. 1990), in 2 FED. SENTENCING REP. 238 (1990) [hereinafter Becker Statement]; Judge Vincent L. Broderick, S.D.N.Y. \& Judge Mark Wolf, D. Mass., Statement before the U.S. Sentencing Comm'n (Mar. 5, 1991), in 3 FED. SENTENCING REP. 276 (1991) [hereinafter Broderick \& Wolf Statement]; Letter from Judge Avern Cohn, E.D. Mich., to Judge Vincent L. Broderick, S.D.N.Y. (June 5, 1991), in 4 FED. SENTENCING REP. 48 (1991); Letter from Judge Vincent L. Broderick, S.D.N.Y., to Judge Avern Cohn, E.D. Mich. (June 13, 1991), in 4 FED. SENIENCING REP. 48 (1991) [hereinafter Broderick Letter]; Letter from Judge Avern Cohn, E.D. Mich., to Judge Vincent L. Broderick, S.D.N.Y. (June 28, 1991), in 4 FED. SENTENCIIG REP. 48, 49 (1991); G. Thomas Eisele, The Sentencing Guidelines System? No. Sentencing Guidelines? Yes., FED. PROBATION, Dec. 1991, at 16; Daniel J. Freed \& Marc Miller, Handcuffing the Sentencing Juäge: Are Offender Characteristics Becoming Irrelevant? Are Congressionally Mandated Sentences Displacing Judicial Discretion?, 2 FED. SENTENCLNG REP. 189 (1989-1990); Letter from Judge Lawrence K. Karlton, E.D. Cal., to Editors, Federal Sentencing Reporter (Nov. 20, 1991), in 4 FED. SENTENCING REP. 186 (1991) [hereinafter Karlton Letter]; Eugene D. Natali, The Probation Officer, Bean Counting and Truth in Sentencing, 4 FED. SENTENCING REP. 102 (1991); Recommendations of the Judicial Conference of the United States to the U.S. Sentencing Commission, in 3 FED. SENTENCING REP. 282 (1991); William W. Schwarzer, Judicial Discretion in Sentencing, 3 FED. SENTENCING REP. 339 (1991); Statement of William W. Schwarzer, U.S. District Judge, N.D. Cal., Concerning Mandatory Minimum Sentences (Jan. 29, 1990), in 2 FED. SENTENCING REP. 186 (1989-1990); Public Hearing on Proposed Amendments to the Sentencing Guidelines (Mar. 5, 1991), reprinted in 3 FED. SENTENCING REP. 287 (1991) [hereinafter Public Hearing] (testimony of Judge Mark Wolf, D. Mass. \& Judge Vincent L. Broderick, S.D.N.Y.); Jose A. Cabranes, Sentencing Guidelines: A Dismal Failure, N.Y. L.J., Feb. 11, 1992, at 2.

For contrary views from federal judges, see Edward R. Becker, Flexibility and Discretion Available to the Sentencing Judge Under the Guidelines Regime, FED. PROBATION, Dec. 1991, at 10; Andrew J. Kleinfeld, The Sentencing Guidelines Promote Truth and Justice, FED. PROBATION, Dec. 1991, at 16; Gerald B. Tjoflat, The Untapped Potential for Judicial Discretion Under the Federal Sentencing Guidelines: Advice for Counsel, FED. PROBATION, Dec. 1991, at 4.

11. MANDATORY MinmMUM PENAlties REPORT, suprce note 4, app. A (listing statutory provisions requiring mandatory minimum terms of imprisonment); see also id. app. B (listing pending mandatory minimum legislation).

12. See id. app. G.

13. See Schulhofer, supra note 2 (manuscript at $42-51$ ).

14. U.S.S.C. IMPACT REPORT, supra note 2, at 103 tbl. 25 (28\% of judges said that guideline sentences were "mostly inappropriate"; $7 \%$ more said they had a mixed opinion); see also Judge Jose Cabranes, "Supposedly 'Scientific Sentencing' is a 'Dismal Failure,"' Address before the University of Chicago Law School (Jan. 15, 1992), in CONN. L. TRIB., Jan. 20, 1992, at 14; Marcia Chambers, Big Moments in The Law During 1990, NAT'L L.J., Dec. 24, 1990, at 13 (Judge J. Lawrence Irving, S.D. Cal., chose to resign rather than be reduced by guidelines to "a clerk toting up numbers" and imposing unjust sentences). 
sentence, ${ }^{15}$ as authorized by section $3553(\mathrm{~b})$ of the SRA; ${ }^{16}$ others are imposing reduced sentences in the wake of low-visibility negotiations between prosecutors and defense attorneys, effectively bypassing the applicable guidelines, mandatory penalties, and appellate court rulings. ${ }^{17}$

The explanation for most of these responses at the trial court level is not hard to understand. A sense of justice is essential to one's participation in a system for allocating criminal penalties. When the penalty structure offends those charged with the daily administration of the criminal law, tension arises between the judge's duty to follow the written law and the judge's oath to administer justice. ${ }^{18}$

As with any tradition-bound system, resistance to change is not unusual. But when professionals most affected by a change criticize it as being unjust, their concerns merit careful consideration.

Introducing simple reforms into a complex system is extremely difficult. This has long been true in the realm of criminal justice. ${ }^{19}$ A radical reform, such as the Commission's guidelines, only increases this difficulty and warrants special attention to the reactions of trial judges, lest the administration of justice be demeaned. ${ }^{20}$

\section{A. The Anatomy of Disparity}

Under the system of criminal sentencing that prevailed for a century prior to the SRA, judges received wide ranges within which to sentence, but no anchoring point from which to begin. ${ }^{21}$ When confronting an individual case,

15. U.S. SENTENCING COMM'N, 1990 ANNUAL REPORT tbl. C-5 (1991) [hereinafter 1990 ANNUAL REPORT].

16. 18 U.S.C. \& 3553(b) (1988).

17. FCSC REPORT, supra note 10, at 138; U.S.S.C. IMPACT REPORT, supra note 2, at 23; lene H. Nagel, Structuring Sentencing Discretion: The New Federal Sentencing Guidelines, 80 J. CRIM. L. \& CRMMNOLOGY 883, 935-39 (1990); Nagel \& Schulhofer, supra note 2 (manuscript at 1-17); Schulhofer, supra note 2 (manuscript at 29); Stephen J. Schulhofer \& Iene H. Nagel, Negotiated Pleas Under the Federal Sentencing Guidelines: The First Fifteen Months, 27 AM. CRM. L. REV. 231 (1989).

18. "The United States wins its point when justice is done its citizens in the courts." This motto is inscribed above the entrance to the office of the Attorney General of the United States. The oath prescribed by statute for federal judges is:

I, [name], do solemnly swear (or affirm) that I will administer justice without respect to persons, and do equal right to the poor and to the rich, and that I will faithfully and impartially discharge and perform all the duties incumbent upon me as under the Constitution and laws of the United States. So help me God.

28 U.S.C. \& 453 (1988).

19. See Malcolm M. Feeley, Court Reform on TRIAL: Why Simple Solutions FaIl 117-18 (1983); D.A. THOMAS, THE PENAL EquATION 461 (1978); Daniel J. Freed, The Nonsystem of Criminal Justice, in LAW AND ORDER RECONSDERED 263, $272-74$ (National Comm'n on the Causes and Prevention of Violence ed., 1969).

20. Franklin E. Zimring, Sentencing Reform in the States: Lessons from the 1970s, in REFORM AND PUNISHMENT 101 (Michael Tonry \& Franklin E. Zimring eds., 1983) (emphasizing value of multiple levels of discretion in justice system).

21. For discussion of the ways in which pre-SRA sentencing judges were left adrift, see sources cited, supra note 9. 
some judges began at the bottom of the statutory range and adjusted sentences upward, according to the severity of the crime and the characteristics of the offender. Other judges started at the top, on the theory that every convicted offender earned the maximum penalty ("do the crime, earn the time"), subject to mitigating circumstances and a discount for pleading guilty. Still others began in midrange, or at some other intermediate point, working up or down as aggravating and mitigating circumstances surfaced. Personal preference dictated each judge's methodology, and the Supreme Court's 1949 decision in Williams v. New York ${ }^{22}$ conveyed the message that any authorized sentence, based on any available information, was likely to survive appeal. Sentences were rarely explained by the sentencer and ordinarily could not be appealed. ${ }^{23}$ Consequently, few courts issued sentencing opinions from which others could seek guidance. ${ }^{24}$

Knowing that a parole board could later modify any prison term imposed in open court, ${ }^{25}$ some judges tried to anticipate parole when formulating a sentence. ${ }^{26}$ Others treated parole consequences as beyond their authority or concern. In either event, the judge lacked power to revise the sentence if her expectations regarding the timing of parole proved incorrect. ${ }^{27}$

The absence of sentencing guidance or review and the omnipresent issue of parole made it inevitable that trial judges would impose different sentences on similarly situated defendants. The perceived purposes of sentencing only compounded the problem: judges often disagreed on whether particular categories of offenders should be incapacitated, rehabilitated, deterred, or punished. ${ }^{28}$ Each of these purposes was legitimate; there were no authoritative criteria for selecting one,${ }^{29}$ and different purposes could lead to quite different sentences.

Studies demonstrated that similar offenders often received different sentences upon conviction of similar crimes. Likewise, offenders with significantly

22. 337 U.S. 241 (1949); see also infra notes 166-67 and accompanying text.

23. Marc Miller, Guidelines Are Not Enough: The Need for Written Sentencing Opinions, 7 BEHAV. SCI. \& L. 3,7 (1989).

24. But see, e.g., United States v. Murphy, 108 F.R.D. 437 (E.D.N.Y. 1985) (outlining common "goals of punishment" pursued through sentencing process); United States v. Bergman, 416 F. Supp. 496 (S.D.N.Y. 1976) (offering detailed summary and examination of sentencing policies and criteria).

25. Under the parole system, sentencing involved a two-stage process: district judges exercised discretion to set the outer limits of prison terms; then, once a prisoner began to serve his sentence, the parole commission exercised discretion to shorten it. Genego et al., supra note 7, at 814-15.

26. Jon O. Newman, A Better Way to Sentence Criminals, 63 A.B.A. J. 1563, 1565 (1977). In order to regularize parole and make it more predictable, the Parole Board developed a system of parole guidelines in the early 1970's. These later received congressional sanction and became predecessors of the Sentencing Reform Act. See Genego et al., supra note 7, at 822.

27. Prior to the SRA, FED. R. CRIM. P. 35 provided for a motion to reduce a sentence, if filed within 120 days. Once that period expired, the sentence was final. In United States v. Addonizio, 442 U.S. 178 (1979), the Supreme Court ruled that the sentencing judge had no jurisdiction to reduce a sentence after the Parole Board refused to grant parole at the point of initial eligibility.

28. S. REP. No. 225 , supra note 9, at 41 \& n.18, reprinted in 1984 U.S.C.C.A.N. at 3224 \& n.18; see also Marc Miller, Purposes at Sentencing, 66 S. CAL. L. REV. (forthcoming Nov. 1992).

29. But see STANTON WHEELER ET AL, SITTING IN JUDGMENT: THE SENTENCING OF WHITE-COLLAR CRMMNALS 166 (1988) (asserting judicial consensus on sentencing criteria and objectives). 
different histories sometimes received identical sentences. In a system without acknowledged starting points, measuring rods, stated reasons, or principled review, unwarranted (or at least unexplained) disparity and disproportionality seemed to flourish. ${ }^{30}$

Some observers placed the blame for disparity on judges. ${ }^{31}$ Others faulted the system: it lacked up-front standards for selecting sentences and had no appellate review to provide principles and precedents. At least one critic found judges rudderless and the system lawless. ${ }^{32}$

\section{B. The Statutory Scheme}

Arguments against unwarranted disparity persuaded Congress, after a decade of study and experimentation with guidelines for the exercise of parole discretion, to structure the discretion of sentencing judges. The theory was that, if judges adhered to rational guidelines for formulating permissible sentences and other participants in the process did their jobs properly, unwarranted disparity would surely decrease.

The first step Congress took to reduce unwarranted disparity was to abolish the United States Parole Commission. For nearly seventy-five years, that agency had post-audited the sentences of imprisoned offenders to determine their suitability for early release. ${ }^{33}$ Congress eliminated the agency to remove the uncertainty it created for sentencing judges, prisoners, and the public. ${ }^{34} \mathrm{Sec}-$ ond, to replace indeterminate sentencing, the SRA empowered district judges-when selecting the sanction of imprisonment- to set determinate terms that offenders would be required to serve in full, less a minor discount for good behavior, ${ }^{35}$ and followed by a period of supervised release. ${ }^{36}$ Third, in place

30. ANTHony PaRtridge \& William B. EldRIDGe, The SeCond Circuit Sentencing Study: A REPORT TO THE JUDGES (1974); $c f$. S. REP. NO. 225, supra note 9, at 41-50, reprinted in 1984 U.S.C.C.A.N. at 3224-33; ALFRED BLUMSTEN ET AL., RESEARCH ON SENTENCING: THE SEARCH FOR REFORM 118-23 (1983); O'DONNELL ET AL., supra note 7, at 1-3; WHEELER, supra note 29, at 166-93. For an examination of parole disparity, see COMPTROLLER GENERAL OF THE UNITED STATES, FEDERAL PAROLE PRACTICES: BetTer MANAGEMENT AND LEgISLATTVE CHANGES ARE NEEDED (1982).

31. See Douglas MCDONALd, ON BLAMINg Judges: CRIMINAL SENTENCING DECISIONS IN NEW YoRK COURTS: ARE GUIDELINES NEEDED TO RESTRAIN JUDGES? 1-2 (1982) (discussing various criticisms of unchecked judicial power to determine criminal sentences).

32. FRANKEL, supra note 7 , at 5 .

33. See Act of June 25, 1910, ch. 387, 36 Stat. 819 (creating boards of parole at each United States Penitentiary); Act of June 25, 1948, ch. 311, 62 Stat. 854 (creating Board of Parole); Parole Commission and Reorganization Act, Pub. L. No. 94-233, § 2, 90 Stat. 219 (1976) (codified at 18 U.S.C. § 4202) (repealed 1984) (renaming Board of Parole as United States Parole Commission).

34. The theory behind indeterminacy was that imprisonment would serve a rehabilitative function: parole authorities would recognize the right moment to permit a reformed prisoner to reenter the community. When that optimistic theory lost credibility, it became evident that a system of uncertain sentences that left prisoners in limbo and deceived the public served no useful purpose.

35. 18 U.S.C. \& 3624(b) (1988).

36. 18 U.S.C. \& 3624(e) (1988). 
of sentence review by a parole board, the SRA authorized courts of appeals to hear appeals from the sentence imposed. ${ }^{37}$

Fourth, the SRA established as the centerpiece of reform a specialized administrative agency, the U.S. Sentencing Commission, to become expert in sentencing research and to devise guidelines for federal judges. The guidelines would "reflect, to the extent practicable, advancement in knowledge of human behavior as it relates to the criminal justice process." 38 A major goal was to reduce "unwarranted sentencing disparities among defendants with similar records who have been found guilty of similar criminal conduct."39

The Commission received no power to sentence offenders, to adjudicate petitions, ${ }^{40}$ or to enforce its own guidelines. The expectation was that the guidelines would be drafted by a nonpolitical group of sentencing experts, ${ }^{41}$ be adopted by a consultative process that took substantial account of prior practice, ${ }^{42}$ and be implemented in a way that encouraged respect from the courts.

The establishment of such a sentencing structure was not unprecedented. ${ }^{43}$ But the manner in which the U.S. Sentencing Commission has carried out federal reform has been disappointing. The new sentencing guidelines are more complex, ${ }^{44}$ inflexible, and severe than those devised by any other jurisdiction. ${ }^{45}$ The Commission has developed and maintained the guidelines with a

37. 18 U.S.C. $\$ 3742(a)(1988)$.

38. 28 U.S.C. \& 991(b)(1)(C) (1988). See generally O'DONNELL ET AL., supra note 7 (reviewing current federal attempts at sentencing reform and proposing alternative sentencing criteria).

39. 28 U.S.C. $\$ 991(b)(1)(B)(1988)$.

40. The Commission does have the authority to review petitions from defendants seeking guideline modification. 28 U.S.C. $\S 994(\mathrm{~s})$ (1988). Only "changed circumstances unrelated to the defendant," however, can trigger such review. Moreover, the Sentencing Act of 1987, Pub. L. No. 100-182, § 23(b), 101 Stat. 1266,1271 , amended $\S 994(\mathrm{~s})$, excusing the Commission from having to justify its disapproval of any such petition.

41. The statute required at least three federal judges to be members of the Commission and made the Attorney General an ex officio nonvoting member. 28 U.S.C. \$ 991(a) (1988). Under Pub. L. No. 98-473, $\S 235$ (b)(5), 98 Stat. 1987, 2033 (1984), reprinted in 18 U.S.C. $\$ 3551$ note, the chairman of the U.S. Parole Commission was also made an ex officio nonvoting member.

42. 28 U.S.C. $\$ 994(m)$ (1988).

43. At the time of the SRA's adoption, guideline commissions were at work in Minnesota and Pennsylvania. See generally ALFRED BLUMSTEIN ET AL., RESEARCH ON SENTENCING: THE SEARCH FOR REFORM 135-39 (1983); PARENT, supra note 7; SANDRA SHANE-DUBOW ET AL., U.S. DEP'T OF JUSTICE, SENTENCING REFORM IN THE UNTTED STATES: HISTORY, CONTENT, AND EFFECT 159-69, 225-28 (1985).

44. See Stephen Breyer, The Federal Sentencing Guidelines and the Key Compromises Upon Which They Rest, 17 HOFSTRA L. REV, 1, 6 (1988). In this article, Judge Breyer constructs a hypothetical sentencing decision, composed of seven distinct steps, illustrating the complexity of the guidelines. He asserts that the guidelines embody a series of interrelated compromises fundamental to criminal justice administration that must be understood as a whole to either critique or alter them.

45. FCSC REPORT, supra note 10, at 135-43; Michael Tonry, The Politics and Processes of Sentencing Commissions, 37 CRIME \& DELINQ. 307, 310 (1991).

In faimess to the Commission, Congress has greatly complicated its task. During the same period in which the guidelines were being developed, Congress spawned an array of federal mandatory penalty laws. See MANDATORY MINIMUM PENALTIES REPORT, supra note 4, app. A (listing approximately 100 separate federal mandatory minimum penalty provisions found in 60 different criminal statutes). When contrasted with the studied deliberation that preceded congressional eractment of the SRA, the congressional effort to create mandatory minimums appears significantly deficient in its methods. Inspired by the outcry over 
process that is less representative, open, and responsive than the procedures by which states undertook similar reforms. ${ }^{46}$ Considering the vital public interests at stake in federal sentencing, the Commission's guidelines development process has been unjustifiably less consultative than the processes by which the Federal Rules of Civil and Criminal Procedure were adopted half a century ago, and by which those rules have been amended ever since. ${ }^{47}$

\section{Questions for Study}

At this juncture, more than seven years after enactment and with much feedback on the guidelines already in hand, an assessment of the SRA should confront several basic questions: Has the Commission accurately perceived the complexity of the sentencing process? In carrying out the research task assigned it by Congress, has the Commission adequately considered the common law principles, purposes, and ideas of justice that judges applied prior to the guidelines? Have sentencing judges and the courts of appeals applied administrative law principles to test the Commission's guidelines against the limitations contained in its enabling statute? Have the guidelines narrowed the discretion of trial judges too far? What assumptions are courts of appeals making about the quiet processes of negotiated dispositions and waivers of appeal, and their impact on disparity in sentencing? Do members of Congress think about the sentencing reform statute when they consider proposals for mandatory penalties? Are sentences today less disparate and more respected than in the preguidelines era?

\section{Sources of Information}

There is a substantial volume of data and comment to consult for answers. As of January 1992, federal district courts had imposed more than 92,000 sentences under the Commission's guidelines. ${ }^{48}$ Courts of appeals have already

society's inability to control drug trafficking and drug violence, these laws form the base upon which mandatory sentences were imposed in nearly 60,000 cases between 1984 and 1990. See id. at 10. The process has produced indiscriminately harsh legislative penalties for drug kingpins and minor couriers alike. Deborah Young, Rethinking the Commission's Drug Guidelines: Courier Cases Where Quantity Overstates Culpability, 3 FED. SENTENCING REP. 63 (1990); see also Broderick \& Wolf Statement, supra note 10, at 279.

46. See PARENT, supra note 7 , at $45-48$.

47. Cf. 28 U.S.C. $\$ \S 2073-2074$ (1988) (allowing for Judicial Conference input into process of adopting federal rules of court). For discussion of the lack of opportunity for judges to influence the Commission, see Broderick Letter, supra note 10; Broderick \& Wolf Statement, supra note 10; Testimony of Judges Vincent L. Broderick and Mark L. Wolf on behalf of the Judicial Conference of the United States before the U.S. Sentencing Commission (Feb. 25, 1992), in 4 FED. SENTENCING REP. (forthcoming Mar.-Apr. 1992) (manuscript at 10, on file with author) [hereinafter Broderick \& Wolf Testimony].

48. William W. Wilkins, Jr., Chairman of the U.S. Sentencing Comm'n, Testimony before the House Subcommittee on Appropriations 2 (Feb. 25, 1992) (transcript on file with author). 
reviewed several thousand cases. ${ }^{49}$ The Commission's annual reports for 1989 and 1990 carefully describe the opening years of the guidelines in operation. ${ }^{50}$ In 1991, the Commission published two more reports: a massive study of the operation of mandatory minimum penalties in the federal system, ${ }^{51}$ and the four-year impact report required by section 236 of the SRA.52

Within the past two years, other studies and scholarly articles have examined the guidelines from a variety of perspectives. These include the April 1990 Report of the Federal Courts Study Committee, ${ }^{53}$ one Commissioner's coauthored examinations of plea bargaining under guidelines before ${ }^{54}$ and after ${ }^{55}$ the Mistretta decision, ${ }^{56}$ a circuit judge's study of guidelines disparity in the Eighth Circuit, ${ }^{57}$ another circuit judge's study of departure jurisprudence, ${ }^{58}$ an analysis of "excessive aggregation" under the guidelines, ${ }^{59}$ a comprehensive examination of the Commission's work in the framework of administrative law principles, ${ }^{60}$ and Commission staff reports containing empirical and legal analyses of discrete issues in guidelines administration. ${ }^{61}$

The General Accounting Office (GAO) will soon complete a study, required by Congress, to determine the impact of the guidelines and to "compare the guidelines system with the operation of the previous sentencing and parole

49. See Albert W. Alschuler, The Failure of Sentencing Guidelines: A Plea for Less Aggregation, 4 FED. SENTENCING REP. 161, 164 n.2 (1991); Hearings Before a Subcomm. of the Comm. on Appropriations of the U.S. Senate, 101st Cong., 2d Sess. 334 (1990) (between 1988 and 1989, criminal appeals rose by almost 2000 cases, or $31 \%$, to 8399 , mostly attributable to the sentencing guidelines).

50. U.S. SENTENCING COMM'N, 1989 ANNUAL REPORT (1989) [hereinafter 1989 ANNUAL REPORT]; 1990 ANNUAL REPORT, supra note 15.

51. MANDATORY MINIMUM PENALTIES REPORT, supra note 4.

52. U.S.S.C. IMPACT REPORT, supra note 2.

53. FCSC REPORT, supra note 10 , at 133-44.

54. Schulhofer \& Nagel, supra note 17; see also Daniel J. Freed \& Marc Miller, Plea Bargained Sentences, Disparity and "Guideline Justice," 3 FED. SENTENCING REP. 175 (1990); Milton Heumann, The Federal Sentencing Guidelines and Negotiated Justice, 3 FED. SENTENCING REP. 223 (1991); Stephen J. Schulhofer \& Ilene H. Nagel, Plea Bargaining under the Federal Sentencing Guidelines, 3 FED. SENTENCING REP. 218 (1990).

55. Nagel \& Schulhofer, supra note 2; see also Schulhofer, supra note 2.

56. Mistretta v. United States, 488 U.S. 361 (1989) (upholding constitutionality of Commission).

57. Gerald W. Heaney, The Reality of Sentencing Guidelines: No End to Disparity, 28 AM. CRIM. L. REV. 161 (1991); cf. William W. Wilkins, Jr., Observations on Judge Heaney's Study, 4 FED. SENTENCLNG REP. 145 (1991) (criticizing Judge Heaney's analysis of federal sentencing guidelines).

58. Bruce M. Selya \& Matthew R. Kipp, An Examination of Emerging Departure Jurisprudence Under the Federal Sentencing Guidelines, 67 NOTRE DAME L. REV. 1 (1991). Judge Selya sits on the U.S. Court of Appeals for the First Circuit.

59. Albert W. Alschuler, The Failure of Sentencing Guidelines: A Plea for Less Aggregation, $58 \mathrm{U}$. CHI. L. REV. 901 (1991) (extended version of Alschuler, supra note 49); see also Morris E. Lasker \& Katherine Oberlies, The Medium or the Message? A Review of Alschuler's Theory of Why the Sentencing Guidelines Have Failed, 4 FED. SENTENCING REP. 166 (1991).

60. Ronald F. Wright, Sentencers, Bureaucrats, and the Administrative Law Perspective on the Federal Sentencing Commission, 79 CAL. L. REV. 1 (1991); see also Samuel J. Buffone, Control of Arbitrary Sentencing Guidelines: Is Administrative Law the Answer?, 4 FED. SENTENCING REP. 137 (1991).

61. See, e.g., U.S. SENTENCING COMM'N, ACCEPTANCE CF RESPONSIBILITY WORKING GROUP REPORT (1991); see also Thomas W. Hutchison, The Bank Robbery Working Group Report, 4 FED. SENTENCING REP. 155 (1991); Ronald Weich, Proposed 1992 Guideline Amendments, 4 FED. SENTENCING REP. 239 (1992). 
release system. ${ }^{362}$ Under the SRA, Congress must then conduct an evaluation to determine: (1) whether the guidelines system has been effective; (2) whether any changes should be made; and (3) whether the parole system should be reinstated in some form and the life of the Parole Commission extended. ${ }^{63}$ As Congress prepares to assess the legacy of its 1984 legislation, it seems particularly appropriate to make a parallel inquiry.

\section{The Structure OF Guideline DeCisionMaking}

The federal sentencing guidelines operate on four sequential levels: policymaking, rulemaking, sentencing, and reviewing. On each level, the system is more complicated than it was in the pre-guidelines era. Before examining the levels in detail, this part introduces them and describes their interrelationships.

\section{A. Policymaking}

Guiding discretion in systems of discretionary justice is not a new idea. ${ }^{64}$ Especially when research shows wide variations in practice, few objections to providing decisionmakers with guideposts or benchmarks should exist. Guidance can identify starting points, in the form of numbers or ranges, as well as principles that articulate or modify past judicial practices. Guidance can structure accurate factfinding because reliable facts will bear a more direct and predictable relationship to sentences in the future than in the unguided past. ${ }^{65}$ Guidance can also spur better representation by encouraging defense and government attorneys to focus on the ultimate disposition of the case from the outset, rather than deferring sentencing concerns until after conviction.

Many forms of guidance exist. Legislatures guide sentencers when they enact minimum and maximum sentences, establish ranges for sentencing discretion, fix mandatory penalties, or establish presumptive sentences. District judges can set useful precedents when they write opinions explaining sentences, ${ }^{66}$ as appellate courts do when they articulate guiding principles or provide reasons for affirming, reversing, or modifying sentences. Some courts have developed voluntary guidelines ${ }^{67}$ or benchmarks. ${ }^{68}$ The District of Columbia

62. Pub. L. No. 98-473, § 236(a)(1), 98 Stat. 1987, 2033 (1984), reprinted in 28 U.S.C. $\S 994$ note (1988).

63. Id. $\$ 236(\mathrm{~b}), 98$ Stat. at 2033 , reprinted in 28 U.S.C. $\S 994$ note.

64. See, e.g., KENNETH C. DAVIS, DISCRETIONARY JUSTICE 3-26, 52-96, $215-33$ (1969) (discussing potential for injustice when decisions involve high degree of discretion).

65. Peter B. Pope, Note, How Unreliable Factfinding Can Undermine Sentencing Guidelines, 95 Yale L.J. 1258 (1986).

66. For illustrative opinions, see United States v. Murphy, 108 F.R.D. 437 (E.D.N.Y. 1985); United States v. Bergman, 416 F. Supp. 496 (S.D.N.Y. 1976).

67. See Tonry, supra note 45 , at 310 .

68. See Memorandum from Chief Judge Irving R. Kaufman of the Second Circuit to District Judges of the Second Circuit on the Sentencing Benchmarks Project (Dec. 26, 1979) (on file with author). 
Superior Court established its own sentencing commission in the mid-1980's, and the Superior Court of Delaware has a Sentencing Accountability Commission, supported by legislation, which structures sentencing discretion using five levels of punishment, only one of which is prison confinement. ${ }^{69}$

When it passed the SRA, Congress envisioned an interactive guidelines process involving federal judges, the Department of Justice, the Probation System, the Bureau of Prisons, and the Federal Public Defenders. ${ }^{70}$ The Commission would research past practice and consult with sentencing judges, prosecutors, defense attorneys, and probation officers to develop acceptable norms. Its early guidance would be rudimentary and would evolve over time. Trial courts, provided with a clearer picture than before of what large numbers of judges had been doing, would receive starting points and principles. They would be authorized to individualize sentences and depart from the guidelines when a case did not fit the guidelines structure, or when Commission guidance failed to take adequate account of circumstances a court found compelling. Their statements of reasons would lay the foundation for appellate review. By reviewing large numbers of cases, courts of appeals would gain a sense of trial court sentencing practice and the parameters of agreement and disagreement with the guidelines. The appellate courts would define common law principles to resolve conflicts.

The Commission would watch this process closely. It would modify or "fine-tune" its guidelines as individual cases illuminated problems. It would heed resistance by courts and lawyers and seek cooperative solutions to difficulties created by the new system.

\section{B. Rulemaking}

The second level in the guidelines process is rulemaking. Prior to 1984, Congress was the sole sentencing rulemaker: it defined the crimes and established their penalty ranges and procedures. In 1984, Congress established the U.S. Sentencing Commission and delegated to it the task of guiding judges within the authorized penalty ranges. ${ }^{71}$ Like Congress, the Commission neither sees offenders nor decides cases. The Commission is an agency of limited authority. Section 3553 of title 18 and sections 991 and 994 of title 28 set out a framework of sentencing factors, policies, inquiries, and guideline prerequisites intended to structure the Commission's work, as well as the procedures for judges.

69. See Tonry, supra note 45 , at 310,315 ; NORVAL MORRIS \& MICHAEL TONRY, BETWEEN PRISON AND PROBATION: INTERMEDIATE PUNISHMENTS IN A RATIONAL SENTENCING SYSTEM 60-63, $75-77$ (District of Columbia); id. at 65-68 (Delaware).

70. 28 U.S.C. $\$ 994(0)(1988)$.

71. 28 U.S.C. $\$ 991$ (1988). 
The Commission's principal task is to draft and periodically modify sentencing guidelines. Guidelines are subordinate to the authorizing statute. They become effective only after complying with the applicable requirements of the Administrative Procedure Act and surviving a six-month period of congressional oversight and review. ${ }^{72}$

The Commission is authorized to promulgate policy statements and commentary. ${ }^{73}$ Unlike guidelines, policy statements and commentary need not be published in the Federal Register, submitted to Congress, or delayed for a waiting period. By themselves, they do not enjoy the force of law, although under 18 U.S.C. $\S 3553(\mathrm{~b})$, they are pertinent to a court's assessment of the adequacy of the Commission's consideration of a guideline. ${ }^{74}$ Noncompliance with a policy statement or commentary is not mentioned as a basis for appeal. ${ }^{75}$

The SRA requires the Commission to develop guidelines based on its study of past sentencing practice, ${ }^{76}$ the purposes of sentencing, ${ }^{77}$ and advancement in knowledge of human behavior as it relates to the criminal justice process. ${ }^{78}$ Promulgated under the Commission's title 28 authority, each guideline must be consistent with all pertinent provisions of title 18 , the statutory provisions that define judicial procedures for sentencing. ${ }^{79}$

In several important respects, the Commission has not followed Congress' rulemaking instructions. Indeed, several of the Commission's guidelines and policy statement rules are inconsistent with the governing statutes. These include the omission of purpose guidelines, despite 28 U.S.C. $\S 991$ (b)(1)(A) and $\S 994(f)$; the prescription of prison sentences for first offenders, despite 28 U.S.C. \& 994(j); the requirement of a government motion before a defendant may receive a reduced sentence on substantial assistance grounds, despite 28 U.S.C. § 994(n); and the issuance of application instructions in section 1B1.1 of the Federal Sentencing Guidelines Manual (Guidelines Manual) that do not follow the statutory sequence described in 18 U.S.C. $\S 3553(a)$.

72. 28 U.S.C. $\$ 994(x)$ (1988) (requiring compliance with Administrative Procedure Act (APA), 5 U.S.C. $\$ 553$ (1988)); 28 U.S.C. $\$ 994$ (p) (1988) (requiring six-month waiting period). In Mistretta v. United States, 488 U.S. 361, 393-94 (1989), the Supreme Court relied on the "report and wait" provision to bolster the constitutionality of the Commission through congressional control.

73. 28 U.S.C. $\$ 994$ (a)(1)-(2) (1988) (delineating topics for guidelines and policy statements).

74. United States v. Williams, 60 U.S.L.W. 4206 (U.S. Mar. 9, 1992).

75. 18 U.S.C. $\$ 3742$ (review of sentence); see also U.S. DEP'T OF JUSTICE, PROSECUTORS HANDBOOK ON SENTENCING GUIDELINES AND OTHER PROVISIONS OF THE SENTENCING REFORM ACT OF 1984, at 33-34 (1987) [hereinafter PROSECUTORS HANDBOOK] (noting that judges need not depart from guideline sentences even if policy statement recommends departure); infra Part V.B.1 (analyzing the guideline/policy statement dichotomy). Compare 28 U.S.C. $\$ 994(n)$ (1988) (guidelines to reflect defendant's substantial assistance) with 28 U.S.C. $\$ 994(\mathrm{t})$ (1988) (policy statements regarding sentence modification).

76. 28 U.S.C. $\$ 994(\mathrm{~m})$ (1988).

77. Id.; see also Miller, supra note 28 .

78. 28 U.S.C. $\$ 991(b)(1)(C)(1988)$.

79. 28 U.S.C. 8 994(a) (1988). 
Rather than holding hearings to examine the growing dismay of judges and practitioners, Congress has assented to virtually all of the Commission's guidelines and amendments by silence. Similarly, courts rarely review a guideline for compliance with the statute before applying it to a case. These omissions have perpetuated critical flaws in the guidance available to judges, as discussed more fully below. ${ }^{80}$

\section{Sentencing}

The third level in the guidelines system consists of an array of sentencers-decisionmakers who see the offender in person and help shape criminal penalties in the case.

In theory, a judge bears sole responsibility for imposing a sentence. In form, guidelines make no change: the "sentence" remains an order of judgment imposed by the trial court following conviction and a sentencing hearing. In fact, however, the nature and severity of sentences have long been the products of discretionary interactions among decisionmakers: a prosecutor, a defense attorney, a probation officer, a judge, and a correctional authority. Each is empowered to make a critical determination or recommendation, prior to or following the judge's formal sentence, to expand, constrain, inform, or modify the ultimate penalty that the offender will bear.

A legislature or agency that attempts to alter sentencing outcomes by imposing strict discipline on judges risks disappointment if it fails to consider these discretionary interactions adequately. Each "sentencer" makes critical choices affecting the sentence in the particular case, and-ultimately-the level of disparity in the sentencing system. A sentence emerges not only from the sequential stages in establishing a sentencing range or modifying it, but from variations in discretionary actions taken by different individuals who play the designated roles within each stage.

There are two primary sentencers under the current guidelines system. The judge is the nominal sentencer in every case and is often the central official performing that task. But more often than before the guidelines, the prosecutor shares and often overshadows the judge's function. For present purposes, the judge and the prosecutor each dominate one of two decisive modes for imposing sentences under the guidelines. One mode may be called sentencing "by the book." The other is sentencing "by the bargain."

The judge sentences "by the book." He imposes sentences in the traditional manner, after following the guidelines and making pivotal determinations of fact. His role is especially salient in posttrial sentencing, although in many guilty-plea cases the judge remains the dominant sentencer. The prosecutor, on

80. See infra Part III.C.2.a (probation); Part III.C.2.b (purposes); Part III.C.2.c (substantial assistance); Part VI.B.1.b. (statutory sequence). 
the other hand, sentences "by the bargain." She, sometimes after consulting with the defense lawyer, determines the charges and often the facts in a plea bargain. These bargains may set unusually tight parameters for judicial sentencing under the guidelines.

The "book" and the "bargain" both differ from pre-guidelines methods. The judge's "book" now includes, in addition to the United States Code, the Guidelines Manual, which the Commission amends each year. The Guidelines Manual is a code of changing regulations that substantially constrain the wide ranges within which judges formerly exercised discretion. It prescribes a starting point for each case, rules for determining criminal history and for adjusting sentences upward and downward, tight ranges for each sentence unless the judge finds a basis for departure, and a sequence for carrying out these steps. ${ }^{81}$

Displacing much of the discretion available in the past, the Guidelines Manual, together with the underlying statute, holds the judge accountable for every sentencing choice. He must state reasons for each sentence, ${ }^{82}$ including a "specific reason" for some sentences, ${ }^{83}$ and his decision is subject to appellate scrutiny. ${ }^{84}$

Plea bargains in the age of guidelines add significantly to the prosecutor's traditional power over charging and guilty pleas. The guidelines do not explicitly confer new power on the prosecutor, nor do they, in a technical sense, "transfer" power from the judge to the Assistant U.S. Attorney (AUSA). But to the extent that the guideline parameters diminish the power of the judge, they correspondingly enhance the power of the prosecutor. ${ }^{85}$

Guidelines are administrative handcuffs that are applied to judges and no one else. When an AUSA negotiates a disposition by setting or reducing charges and identifying relevant facts, she effectively restricts the judge's sentencing range and, consequently, the ambit within which upward and downward adjustments can make a difference. The judge in this sense becomes a handcuffed decisionmaker, rather than the "black box" sentencer of the past who was free to roam at will throughout the statutory range. ${ }^{86}$ The judge's sentencing range is now tethered to the prosecutor's choice of charges and facts, unless the probation officer's independent inquiry brings some facts into

81. U.S.S.G., supra note $1, \S 1 \mathrm{~B} 1.1$.

82. 18 U.S.C. § 3553 (c) (1988).

83. 18 U.S.C. \& 3553(c)(2) (requiring "specific reason" for sentence outside of the Commission's sentencing range).

84. 18 U.S.C. \& 3742 (1988).

85. See Natali, supra note 10, at 103 ("The main intent of these [plea] bargains ... was to subvert the impact of the guidelines and, since it appeared that the judge had little discretion to individualize sentencing, this function was taken over by lawyers."); Saul M. Pilchen, The Federal Sentencing Guidelines and Undercover Sting Operations: A Defense Perspective, 4 FED. SENTENCING REP. 115, 115 (1991) (in cases involving undercover sting operations, the guidelines "have reduced judicial discretion in sentencing and increased prosecutorial control.").

86. $C f$. Heumann, supra note 54 , at 225 (noting that guidelines "dramatically limit judicial sentencing discretion"). Because the sentencing judge did not have to proffer reasons, he was often referred to as a "black box" sentencer. 
question. Only when the prosecutor and judge see eye to eye does the close correlation between AUSA charges and facts and the judge's sentence not distort the outcome. If they do not agree, however, disparity may be introduced.

Congress clearly intended to structure and narrow judicial discretion by developing guidelines. But comparatively few commentators anticipated the extent to which enhanced prosecutorial power would fill the judicial vacuum created by the guidelines. The resulting impact of the guidelines on the dynamics of federal sentencing, discussed in Part IV below, far exceeds most predictions.

\section{Reviewing}

The fourth level in the guidelines system consists of two types of review: sentence review and guideline review. Courts of appeals review sentences on a regular basis. ${ }^{87}$ And district courts as well as courts of appeals have the power to review guidelines.

Jurisdiction to review sentences in the courts of appeals is new under the SRA. ${ }^{88}$ Each court of appeals has concurrent review responsibilities: it hears appeals from individual sentences in order to determine their conformity to the guidelines; and, as part of those appeals, it hears challenges to particular guidelines to assure that they conform to the United States Code.

Both the defendant and the government can appeal a sentence. ${ }^{89}$ The court of appeals must give due regard to the trial judge's unique opportunity to assess the credibility of witnesses. The court of appeals must also accept the sentencer's findings of fact unless they are clearly erroneous, and must accord due deference to the district court's application of the guidelines to the facts. ${ }^{90}$ In terms of chronology, the district court should initially determine the applicable guideline and compare it with the underlying statute. If the guideline is authorized, and its application to the case makes sense, that inquiry need not be carried further.

But if the guideline raises a question of "fairness," range that seems too low or too high-if it seems either insufficient or "greater

87. The Supreme Court retains ultimate authority to review both sentences and guidelines, but rarely does so.

88. 18 U.S.C. $\S 3742$ (1988). But see Robert J. Kutak \& Michael Gottschalk, In Search of a Rational Sentence: A Return to the Concept of Appellate Review, 53 NEB. L. REV. 463, 463-71 (1974). Between 1879 and 1891, circuit courts (which became courts of appeals under the Circuit Court of Appeals Act of 1891, 26 Stat. 826) had jurisdiction to review all federal criminal sentences, except those involving fines of $\$ 300$ or less.

89. 18 U.S.C. $\$ 3742$ (a)-(b).

90. Id. $\$ 3742$ (d). A more intrusive standard of review may undermine the Commission's goals. In United States v. Wright, Judge Breyer, a former commissioner, noted that "more intensive appellate review might hinder the Commission's legal power and expressed intention to collect information about how the district courts apply the Guidelines and to revise them in light of what it learns." 873 F.2d 437, 444 (Ist Cir. 1989) (applying clearly erroneous standard).

91. 28 U.S.C. $\S 991(b)(1)(B)(1988)$. 
than necessary"92 - the court may consider a departure. In such cases, the court's inquiry should focus on whether the Commission adequately considered the kind or degree of circumstances, aggravating or mitigating, present in the case. The departure provision of 18 U.S.C. $\S 3553$ (b) explicitly mandates an "adequacy" review by instructing the district court to impose a sentence within the guidelines

unless the court finds that there exists an aggravating or mitigating circumstance of a kind, or to a degree, not adequately taken into consideration by the Sentencing Commission in formulating the guidelines that should result in a sentence different from that described. In determining whether a circumstance was adequately taken into consideration, the court shall consider only the sentencing guidelines, policy statements, and official commentary of the Sentencing Commission.

This congressional invitation for judicial review of a guideline's applicability is a matter of paramount importance. Review is not limited to determining whether the Commission merely "considered"-i.e., mentioned-a subject. Rather, the test focuses on the adequacy of the consideration. It holds the Commission accountable with respect to the quality of the guideline and assures courts that they need not follow ill-considered limitations on their discretion.

By scrutinizing the three permissible sources-the guidelines, the policy statements, and the commentary-for indications of how carefully the Commission considered the substance of the guideline at issue, a district judge fulfills a basic statutory purpose: to maintain "sufficient flexibility to permit individualized sentences when warranted by mitigating or aggravating factors not taken into account in the establishment of general sentencing practices. ${ }^{193}$ Unfortunately, such scrutiny is infrequent. Judicial oversight of the Commission has not been pursued with sufficient diligence with respect to the process of guideline formulation, ${ }^{94}$ or to the substantive instructions governing guideline content. ${ }^{95}$ As a consequence, the Commission has not been pressed to meet its burden of justifying those aspects of the guidelines that cause difficulties in the courts.

Over the past four years, a colleague and I randomly examined judges' sentencing transcripts and statements of reasons. ${ }^{96}$ We found that courts rarely compare a guideline to the text of the SRA. ${ }^{97}$ Many judges seem to assume

92. 18 U.S.C. \& 3553(a) (1988).

93. 28 U.S.C. $\$ 991(\mathrm{~b})(1)(B)(1988)$.

94. The courts have not ensured that the Commission complies with the "research base" requirement of 28 U.S.C. \$\$ 991(b)(2) (1988), 994(o) (1988), the "reasons" requirement of 28 U.S.C. § 994(p) (1988), or the "policy statement/guideline" distinction of 28 U.S.C. \& 994(a)(2), (7) (1988).

95. 28 U.S.C. \& 994 (1988); see also infra Parts V.B, VI.A.3.

96. Statements of reasons are required by 18 U.S.C. $\S 3553$ (c) (1988).

97. In the early days of the guidelines, the Federal Sentencing Reporter received large numbers of sentencing statements from judges in all parts of the country. Those statements rarely cited authorities other than the guidelines and policy statements by themselves. This observation remains largely true today in the 
that the Guidelines Manual fully codifies the law of sentencing and that nothing can be done about a troublesome guideline unless Congress acts. Principles of administrative law, which courts usually follow when reviewing agency actions, seem to be forgotten when judges themselves are called upon to apply questionable sentencing regulations. ${ }^{98}$ It is paradoxical that district judges who are outspoken critics of the guidelines have been lax in responding to Congress' invitation to review guideline validity.

It is equally important for the circuit courts to review the guidelines for conformity to the statute. Searching review is especially appropriate given Commission policy statements indicating a willingness to revise the guidelines based on reasoned departures by district courts. ${ }^{99}$

Instead of holding the Commission accountable, however, courts of appeals have concentrated on restricting the discretionary actions of district courts. One might expect that the difficult transformation of sentencing heralded by the SRA, the concerns voiced by district judges about the new system's fairness and rationality, the statutory requirement of appellate deference to district courts, and the Commission's welcome view of guidelines as an evolutionary system ${ }^{100}$ all would prompt appellate courts to grant greater latitude to trial court discretion in the early years of the new system. In fact, a number of circuit courts have adopted surprisingly restrictive standards in reviewing district court departures. ${ }^{101}$ Part V describes the adverse impact of these standards on guideline compliance and sentencing disparity. But before looking at district and appellate court responses to the guidelines, it is important to examine the Commission's work.

\section{THE COMMISSION AT WORK}

This part examines how the Commission interpreted its statutory mandate, what policy choices it made, and how the system functions in practice as illustrated by some of the most troublesome guidelines and policy statements. ${ }^{102}$

unsolicited statements and transcripts we receive from various courts. For two early and striking exceptions to this statement, see United States v. Rodriguez, 724 F. Supp. 1118 (S.D.N.Y. 1989), and United States v. Birchfield, 709 F. Supp. 1064 (M.D. Ala. 1989).

98. Wright, supra note 60 ; see also Buffone, supra note 60 .

99. U.S.S.G., supra note 1, ch.1, pt. A, intro. 4(b); see also Rodriguez, 724 F. Supp. at 1122-23 (noting that judges should depart from guidelines in appropriate cases to aid the Commission in its future revisions).

100. See U.S.S.G., supra note 1, ch.1, pt. A, intro. 4(b) (referring to "progressive changes" in light of accumulated future judicial sentences).

101. See Marc Miller \& Daniel J. Freed, Honoring Judicial Discretion Under the Sentencing Reform Act, 3 FED. SENTENCING REP. 235, 237-38 (1991).

102. Note, for example, the Commission's failure to mention or implement 18 U.S.C. $\$ 3553$ (a)'s provision for parsimony ("sufficient, but not greater than necessary"); 28 U.S.C. § 994(g)'s provision for guidelines "formulated to minimize the likelihood that the Federal prison population will exceed the capacity of the Federal prisons"; and $\$ 994(j)$ 's demand that the guidelines "reflect the general appropriateness of imposing a sentence other than imprisonment" on first offenders who have "not been convicted of a crime 


\section{A. Statutory Instructions}

To guide the Commission, Congress set forth principles based on preguidelines federal practice and on Minnesota's pioneering experience with the nation's first sentencing commission. ${ }^{103} \mathrm{~A}$ single section, 18 U.S.C. § 3553(a), captured the elements of contemporary sentencing. ${ }^{104}$ The goal was an adequate but parsimonious sanction: "a sentence sufficient, but not greater than necessary, to comply with the purposes" of sentencing. The section directed the sentencer to begin the inquiry by looking into "the nature and circumstances of the offense and the history and characteristics of the defendant." 105 These facts, in turn, would help shape the next step: the sentencer's choice from among the traditional purposes of sentencing, including proportionate punishment, deterrence, protection of the public, and rehabilitation. ${ }^{106}$

of violence or an otherwise serious offense."

The federal prison population at last report stood at $165 \%$ of capacity. Attorney General William P. Barr, Remarks to the California District Attomeys Association (Jan. 14, 1992). The Commission offers the following explanation for providing imprisonment for every first offender, contrary to the explicit statutory instructions of 28 U.S.C. $\$ 994$ (j) (1988):

The Commission's solution to this problem has been to write guidelines that classify as serious many offenses for which probation previously was frequently given and provide for at least a short period of imprisonment in such cases. The Commission concluded that the definite prospect of prison, even though the term may be short, will serve as a significant deterrent, particularly when compared with pre-guidelines practice where probation, not prison, was the norm.

U.S.S.G., supra note 1 , ch. 1, pt. A, intro. 4(d). This extraordinary explanation, accompanied by no research into pre-guidelines probation, recidivism, or deterrence findings, runs contrary both to Congress' instructions that all purposes of sentencing were to be available to judges and to the findings of the National Academy of Sciences report, see BLUMSTEIN ET AL., supra note 30 .

103. See PARENT, supra note 7. The findings of BLUMSTEN ET AL., supra note 30 (panel created in response to National Institute of Justice request to National Academy of Sciences), were highly supportive of the Minnesota Sentencing Guidelines Commission. Most states that adopted "presumptive" guidelines followed the Minnesota model. For a discussion of "presumptive" sentencing guidelines like those of Minnesota, see Tonry, supra note 45. Minnesota guideline commission staff assisted Oregon in the development of its guidelines system. See Kathleen Bogan, Oregon's Sanction Units Exchange System for Felony Sentencing Guidelines, 4 FED. SENTENCING REP. 36 (1991). While Congress attempted to adopt such a model, the Commission has tumed itself and the guidelines into something much different and much less effective than Minnesota's sentencing scheme. See Marc Miller, True Grid: Revealing Sentencing Policy, 25 U.C. DAVIS L. REV. 301, 303 (forthcoming 1992) (contrasting "communicative and functional possibilities of a simple, clear grid" to complexity of federal guidelines' grid, which "makes it difficult to assess the basic policy choices about offenses and offenders that lead each convicted defendant to one of its boxes").

104. 18 U.S.C. \& 3553(a) (1988); see also Daniel J. Freed \& Marc Miller, Taking "Purposes" Seriously: The Neglected Requirement of Guideline Sentencing, 3 FED. SENTENCING REP. 295 (1991); Miller, supra note 28 , (manuscript at $27-30$, on file with author) (examining $\$ 3553$ (a) "purposes" requirement with U.S.S.G., supra note $1, \S 1 \mathrm{~B} 1.1$, which ignores relevance of purpose in determining a sentence).

105. 18 U.S.C. $\$ 3553$ (a)(1). Congress also directed the Commission to ensure "sufficient flexibility to permit individualized sentences," 28 U.S.C. § 991(b)(1)(B) (1988) (setting forth various instructions regarding offender characteristics). See also 28 U.S.C. $\$$ 994(d)-(e) (1988) (instructing Commission to consider "relevance" of certain offender characteristics, but cautioning against considering them for prison sentences). The wording of these sections has caused some confusion in the courts, see infra Part III.C.3. The Senate report accompanying the SRA provides guidance to commissioners and judges for preserving sentencing flexibility. S. REP. No. 225, supra note 9, at 161, reprinted in 1984 U.S.C.C.A.N. at 3334 (discussing 28 U.S.C. $\$ 991$ ).

106. 18 U.S.C. $\& 3553(\mathrm{a})(2)(1988)$. 
Next, the statute directed attention to the "kinds of sentences available": ${ }^{107}$ prison, probation, fines, and restitution. ${ }^{108}$ At this point, with facts, purposes, and options clearly in mind, the sentencer was instructed to turn to "the kinds of sentence and the sentencing range established for the applicable category of offense committed by the applicable category of defendant as set forth in the guidelines" and any pertinent policy statement. ${ }^{109}$ The section concluded with an admonition to consider two specific needs: "the need to avoid unwarranted sentence disparities among defendants with similar records who have been found guilty of similar conduct" and "the need to provide restitution to any victims of the offense." 110

Section 3553(b) clarified the court's authority to assess the adequacy of the guidelines and to depart from the guideline range when necessary. To make the process visible, to explain its departures, and to facilitate appeals, § 3553(c) directed the sentencing judge to state in open court the reasons for his or her sentence. If the sentence differed in kind or degree from that prescribed in the guidelines, the court was to state "the specific reason for the imposition of a sentence different from that described."111

The title 28 sections establishing the Commission incorporated additional principles. These principles include the general appropriateness of not imprisoning first offenders, ${ }^{112}$ of imposing a prison term on persons convicted of violent crimes resulting in serious bodily injury, ${ }^{113}$ and the general inappropriateness of imprisonment for rehabilitation. ${ }^{114}$ The statute set forth a preference for incremental penalties for multiple offenses and a presumption against consecutive sentences for the crime of conspiring to commit an offense and for the underlying substantive offense. ${ }^{115}$ Finally, recognizing the central importance of capacity constraint to the success of the Minnesota guidelines, the statute instructed the Commission to "minimize the likelihood that the Federal prison population will exceed the capacity of the Federal prisons."116

107. Id. § 3553(a)(3) (1988).

108. 28 U.S.C. $\$ 994$ (a)(1)-(2) (1988). 18 U.S.C. $\$ 3551$ (b) (1988), sets out the authority for prison, probation, and fines. 18 U.S.C. $\S 3553(\mathrm{a})(7)$ (1988), requires restitution to be considered.

109. 18 U.S.C. \& 3553(a)(4) (1988).

110. $I d . \S 3553(a)(6)-(7)$.

111. 18 U.S.C. \& $3553(\mathrm{c})(2)(1988)$.

112. 28 U.S.C. \& $994(\mathrm{j})(1988)$.

113. $I$ ld.

114. Id. § 994(k) (1988) ("inappropriateness of imposing a sentence to a term of imprisonment for the purpose of rehabilitating the defendant").

115. Id. $\$ 994(v)$ (1988) ("limiting consecutive terms of imprisonment for an offense involving a violation of a general prohibition").

116. Id. $\$ 994(\mathrm{~g})(1988)$; Pub. L. No. 98-473, 98 Stat. 1987, 2021 (1984) (codified at 28 U.S.C. $\$ 994(\mathrm{~g})$ ) (suggesting guidelines should be formulated to reduce the chance that federal prison population not exceed federal prisons capacity); see also PARENT, supra note 7, at 6-7, 40-45, 92-93, 107, 188-92 (describing Minnesota's policy of capacity constraint). 


\section{B. Policy Choices}

The Commission inaugurated its guidelines in 1987 by articulating a number of thoughtful policy decisions. In a wide-ranging and well-reasoned introduction to the Guidelines Manual, it directed courts to view guidelines "as carving out a "heartland" of typical cases. ${ }^{117}$ Judges, the Commission explained, could depart in unusual or aberrant cases, or when aggravating or mitigating circumstances required sentences more or less severe than the applicable guideline range. This departure policy generously allowed a sentencer to decide when the guidelines did not fit the needs of a case: "The controlling decision as to whether and to what extent departure is warranted can only be made by the courts."118 The policy statement identified a number of factors "that the Commission has not been able to take into account fully in formulating the guidelines," and noted that any case might involve factors that "have not been given adequate consideration by the Commission."

The Commission also set out an "evolutionary" philosophy that portrayed the early guidelines as the beginning of a long process of trial and error- of adjustment in response to feedback from courts. The Commission seemed to have adopted a flexible approach to a difficult area of law, committing itself to continuing dialogue with the judiciary. ${ }^{120}$

\section{Guidelines in Action}

The appealing introduction to the 1987 Guidelines Manual has been overwhelmed by the complexity, rigidity, severity, uniformity, and disproportionality of the guidelines and sentences that followed. ${ }^{121}$ Problems appeared on many levels; this discussion illustrates a few. Published studies, reports, and cases, from the Commission as well as its critics, ${ }^{122}$ tell the basic story. Conversations and correspondence with federal judges, prosecutors, federal defenders, and probation officers over the past five years illuminate data reported by others. ${ }^{123}$

117. See U.S.S.G., supra note 1 , ch. 1, pt. A, intro. 4(b).

118. Id. \& $5 \mathrm{~K} 2.0$.

119. Id.

120. One troublesome policy choice relating to the purposes of sentencing is discussed infra Part III.C.2.b. See also U.S.S.G., supra note 1, ch. 1, pt. A; Miller, supra note 28.

121. Judges and practicing attorneys expressed strong vocal opposition to the guidelines in the summer of 1987. See, e.g., Ad Hoc Sentencing Study Group, Assessing the Guidelines of the United States Sentencing Commission (1987) (unpublished report, on file with author); FCSC REPORT, supra note 10. For a critique of the intricacy and complexity of the guidelines, see Miller, supra note 103, at 322-23.

122. See, e.g., The Sentencing Commission and Its Critics, 2 FED. SENTENCING REP. 205-52 (1990) (collection of commentary on the work of the Commission).

123. This dialogue culminated in the Sentencing Institute for the Second and Eighth Circuits in Lexington, Kentucky, on March 1-4, 1992. In addition to several members of the Commission, a host of federal judges, practitioners, and scholars attended this conference. 


\section{Disproportionality}

An essential component of solving the problem of unwarranted disparity lies in distinguishing between like cases, which ought to be sentenced similarly, and unlike cases, which ought to be sentenced in proportion to their greater or lesser seriousness. ${ }^{124}$ The Commission acknowledged this problem in its original Guidelines Manual by distinguishing between "uniformity" and "proportionality,"125 but it did not adequately address the proportionality issue. One Commissioner candidly acknowledged this deficiency in a 1990 law review article; ${ }^{126}$ the December 1991 Impact Report discussed it briefly and found "no completely satisfying solution."127

The Commission's theory of proportionality is that cases falling in the higher ranges of its mathematical matrix are uniformly more serious than those in the lower ranges. But in the real world of sentencing, cases do not "fall" by themselves. People evaluate them. Judges, prosecutors, and probation officers confront large numbers of cases each year. They deal with thousands of cases as they accumulate experience over the course of maturing careers. Examining each case individually, they learn to distinguish between serious-sounding crimes that are relatively minor, ${ }^{128}$ and serious crimes that are gravely dangerous. They come to recognize relatively minor crimes that involve exceptionally culpable or high-risk offenders, ${ }^{129}$ and crimes so marginal that prosecutors decline to file charges or dismiss them, or judges enter pretrial diversion orders to avoid the usual adjudication process. ${ }^{130}$

Many cases are difficult to capture on a sentencing grid. The guidelines provide for adjustments on seemingly sound grounds, ${ }^{131}$ but the arithmetic

124. S. REP. No. 225, 98th Cong., 1st Sess. 158 (1983); see also David Sudnow, Normal Crimes: Sociological Features of the Penal Code in a Public Defender Office, 12 SOC. PROBS. 255, 259-64 (1965) (discussing proportionality rules developed around "typical" or "normal" crimes to account for aggravating and mitigating factors).

125. In a policy statement entitled "The Basic Approach," the Commission distinguished the two goals: "Second, Congress sought reasonable uniformity in sentencing by narrowing the wide disparity in sentences imposed for similar criminal offenses committed by similar offenders. Third, Congress sought proportionality in sentencing through a system that imposes appropriately different sentences for criminal conduct of differing severity." U.S.S.G., supra note 1 , ch. 1 , pt. A, intro. 3.

126. Nagel, supra note 17 , at $934-35$ ("While every effort was made to treat like offenders alike, less attention was given in the first set of guidelines, partly because of time constraints, to the possibility of over or under-defining like offenders.").

127. See U.S.S.C. IMPACT REPORT, supra note 2, at 16-18.

128. For example, "robbery" covers a large range of behavior, much of it relatively minor (e.g., pickpocketing).

129. For example, the notorious gangster AI Capone was convicted of tax evasion. For a discussion of the Internal Revenue Investigation, see generally FRANK SPIERING, THE MAN WHO GOT CAPONE (1976). See also United States v. Kikumura, 918 F.2d 1084, 1118 (3d Cir. 1990) (district court imposed upward departure sentence 10 times the guideline range because offense circumstances were unusually heinous).

130. See COMPTROLlER GENERAL, REPORT TO CONGRESS: U.S. ATtORNEYS DO NOT PROSECUTE MANY SUSPECTED VIOLATORS OF FEDERAL LAWS, at i (1978).

131. For example, the Guidelines Manual provides for adjustments on the basis of criminal history, U.S.S.G., supra note $1, \S \S 4 \mathrm{Al} .1-4 \mathrm{~B} 1.4$, substantial assistance to authorities, id. $\S 5 \mathrm{~K} 1.1$, and role in the offense, id. $\S \S 3 \mathrm{~B} 1.1-.2$. 
of calculating adjustments sometimes produces ridiculous results. ${ }^{132}$ The application of the "substantial assistance" adjustment in drug courier cases, for example, results in serious imbalances by producing unduly severe sentences for "mules" who know little about the drug syndicates for which they work and unduly lenient sentences for substantial drug dealers who tell all after their arrest by DEA agents. 133

Too often, the Commission's remedy for disparity is uniformity or, in Albert Alschuler's term, "aggregation," meaning "the treatment of many cases all at once." ${ }^{134}$ In its overriding quest to forestall disparity, the Commission tends to apply the same measuring rods to persons of widely varying culpability, frequently leading to bizarre results like those illustrated in Alschuler's essay. ${ }^{135}$

But the SRA did not target sentence "disparity" per se. Instead, it targeted "unwarranted sentence disparities." ${ }^{\text {"136 }}$ Disparity is a surface phenomenon. It raises the question: why are two seemingly similar cases sentenced differently? When the answer is persuasive in terms of the nature and circumstances of the offense, the history and characteristics of the offender, and the purposes of sentencing, the apparent disparity is in fact warranted. When the disparity cannot be satisfactorily accounted for, it is unwarranted.

Most serious-sounding cases deserve to be sentenced more severely than most minor-sounding cases, but the name of the crime only initiates the inquiry. Each case involves unique offenders and offense circumstances, and their underlying stories - of need or greed, of recklessness or malice, in mitigation or aggravation ${ }^{137}$-need to be assessed and sentenced by experienced professionals exercising human judgment. Numerical "offense levels" are useful in launching the sentencing process, but they are woefully unreliable as substitutes for judges. A proportionality inquiry ought to begin with the guidelines, but only judgment calls can credibly confirm or vary proportional sentences. Seven years after the SRA became law, the Commissioners still have not learned this lesson.

132. See e.g., United States v. Rodriguez, 724 F. Supp. 1118, 1122 (S.D.N.Y. 1989) (constructing hypothetical demonstrating how cases with widely divergent circumstances may require comparable sentences under the guidelines).

133. See Catharine M. Goodwin, Sentencing Narcotics Cases Where Drug Amount is a Poor Indication of Relative Culpability, 4 FED. SENTENCING REP. 226 (1992); Young, supra note 45. On February 19, 1992, the Ninth Circuit sustained a downward departure to probation for two Mexican drug "mules" in a marijuana case, on the ground that the relative harmlessness of "mules" was not adequately taken into account by the guidelines. United States v. Valdez-Gonzalez, Nos. 89-10274, 89-10330, 1992 WL 26494 (9th Cir. Feb. 19, 1992).

134. Alschuler, supra note 59, at 904; see also Schulhofer, supra note 2.

135. Alschuler, supra note 59; see also Goodwin, supra note 133; Young, supra note 45.

136. 18 U.S.C. $\$ 3553(a)(6)$ (1988) (citing "need to avoid unwarranted sentence disparities among defendants with similar records"); 28 U.S.C. $\$ 991$ (b)(1)(B) (1988) (same).

137. See WHEELER ET AL., supra note 29 , at $81-123$. 


\section{The Appropriate Level of Severity}

In enacting the SRA, Congress clearly sought to increase the level of imprisonment for certain crimes. It identified those crimes in $\$ 994$, instructing the Commission, for example, to specify prison terms "at or near the maximum" for career offenders who commit crimes of violence or drug offenses, and to assure "substantial" terms of imprisonment for other designated crimes. ${ }^{138}$ At the same time, however, Congress also sought to reduce unnecessary imprisonment in other kinds of cases. First offenders were one explicit illustration; ${ }^{139}$ others were persons in need of rehabilitation or training, ${ }^{140}$ and those who provided substantial assistance in the investigation of crimes. ${ }^{141}$ This section discusses four areas in which Commission guidance affecting sentence severity is flawed: probation, purposes, substantial assistance, and relevant conduct.

\section{a. Probation}

Prior to the SRA, the prison to probation ratio in federal criminal sentencing was about sixty to forty. ${ }^{142}$ Congress said nothing in the statute about abolishing or even drastically curtailing probation. It provided extensively for probation sentences in $\S \S 3561-3565$ of title 18 and made all offenders up through class C-felony offenders eligible for probation. ${ }^{143}$ The Commission, however, drafted guidelines containing a presumptive sentence of imprisonment for every felony in the United States Code. Near the bottom of the scale of crimes, it established several ranges in which a court could select either prison or probation. Because courts of appeals regularly decline to review sentences falling within the correct guideline range, ${ }^{144}$ and regularly refuse to review failures to depart from a guideline, ${ }^{145}$ no appeal is available if a judge rejects

138. 28 U.S.C. § 994(h)-(i) (1988).

139. See, e.g., id. § 994(j) (1988) ("The Commission shall insure that the guidelines reflect the general appropriateness of imposing a sentence other than imprisonment in cases in which the defendant is a first offender who has not been convicted of a crime of violence or an otherwise serious offense ....").

140. Id. $\S 994(\mathrm{k})$ (1988) ("inappropriateness of imposing a sentence to a term of imprisonment for the purpose of rehabilitating the defendant").

141. Id. § 994(n) (1988) (authorizing imposition of "lower sentence than would otherwise be imposed, including a sentence that is lower than that established by statute as a minimum sentence, to take into account a defendant's substantial assistance in the investigation or prosecution of another person who has committed an offense").

142. Broderick \& Wolf Testimony, supra note 47.

143. 18 U.S.C. $\S \S 3559,3561,3581$ (1988). The effect of these provisions is to make any person convicted of a federal offense carrying a maximum term of imprisonment of less than 25 years eligible for probation, unless probation has been expressly precluded by law.

144. See David Yellen, Should Judges Take Seriously the Sentencing Commission's Standards for Accepting Plea Agreements?, 3 FED. SENTENCING REP. 216, 216 (1991).

145. See infra Part V.B.3.b. Some appellate courts will review a failure to depart if the trial judge was unaware of his right to consider a departure under 18 U.S.C. § 3553(b) (1988). 
probation. The result is that the incidence of probation since the guidelines has been cut by more than half. ${ }^{146}$

A penal system that employs an effective spectrum of intermediate punishments could rationally decide to limit both prison and probation. ${ }^{147}$ It could insert intermediate sanctions such as community service, home confinement, work release, day fines, restitution, and split sentences on the spectrum between straight probation for some offenders and longer terms for the violent, dangerous, or otherwise grave offenders for whom "just deserts" or public protection demands extended imprisonment. ${ }^{148}$ This, however, is not the policy choice articulated in the Commission's Guidelines Manual.

Instead, the opening policy statement explains that its "solution" to the probation problem

has been to write guidelines that classify as serious many offenses for which probation was previously given and provide for at least a short period of imprisonment in such cases. The Commission concluded that the definite prospect of prison, even though the term may be short, will serve as a significant deterrent, particularly when compared with preguidelines practice where probation, not prison, was the norm. ${ }^{149}$

Nowhere in the Guidelines Manual did the Commission identify the research that led it to conclude that prior federal probation practice had been ineffective, or that prescribing prison terms for those who would have received probation would "serve as a significant deterrent." Deterrence literature raises significant doubts about the capacity of a penalty structure to deter crime in situations where would-be offenders do not believe that the probability of detection, arrest, prosecution, conviction, and sentence is significant. ${ }^{150} \mathrm{Re}-$ search suggests that deterrence makes the most sense in situations where the likelihood of apprehension and punishment is high, or where the targeted population fears the prospective penalty and conforms its conduct accordingly. ${ }^{151}$ The Commission might well have shown the applicability of these principles to some crimes and some types of offenders. By instead eliminating

146. 1990 ANNUAL REPORT, supra note 15, tbl. C-4. For "type of guideline sentences imposed," "probation only" constituted $15.5 \%$, while prison, split sentences, and "probation with confinement" totaled $84 \%$. Id.

147. See generally MORRIS \& TONRY, supra note 69 , at 9-33.

148. See VON HIRSCH, supra note 9, at 66-76.

149. U.S.S.G., supra note 1 , ch. 1, pt. A, intro. 4(d).

150. See Andrew Ashworth, Sentencing Purposes in England, 3 FED. SENTENCING REP. 337, 338 (1991) ("For the vast majority of crimes, increasing the sentence level in the hope of deterring others has little effect because of ... . the belief that the risk of detection is low.").

151. See FRANKLIN E. ZMMRING \& GORDON J. HAWKINS, DETERRENCE 158-72 (1973) (describing various studies and arguing "applicability" and "credibility" of threat are key determinants of deterrence); see also United States v. Bergman, 416 F. Supp. 496, 498-99 (1976) (describing when deterrence is an appropriate purpose of sentencing); $c f$. CESARE BECCARIA, ON CRIMES AND PUNISHMENTS 74-75 (David Young ed., Hacket Publishing Co. 1986) (1764) (to prevent crime, laws must be clear, simple, and enforced consistently throughout the nation). 
or curtailing probation indiscriminately, it shirked its responsibility to demonstrate the nexus between its unprecedented penal policy and knowledge about crime and justice.

\section{b. Purposes}

The SRA's most prominently featured element of sentencing in individual cases is the "purposes of sentencing." After enumerating them in 18 U.S.C. $\S 3553$ (a), Congress referred to purposes seventeen times in the course of its instructions to the Commission and the courts. ${ }^{152}$

These statutory references are not written as a congressional preamble to the general question of why society punishes convicted offenders, a matter that has divided philosophers and criminologists for centuries. Rather, they are written to delegate the purpose decision to individual sentencers, subject to the Commission's informed guidance. They identify a case-specific determination each judge must make when sentencing an individual offender: which congressional purpose shall I serve by my sentence in this case? This is a question to which the Commission should give guidance in the future, but to date it has failed to do so.

The Commission misconstrued the purpose provisions of the statute, attempting unsuccessfully to identify a single purpose to cover all cases. It discusses this attempt in the Introduction to its Guidelines Manual. "A philosophical problem arose," it explained, "when the Commission attempted to reconcile the differing perceptions of the purposes of criminal punishment."153 It then discussed two "purposes," crime control and just deserts, saying that adherents of each had urged it to choose between them. The Commission declined to choose between them:

As a practical matter ... this choice was unnecessary because in most sentencing decisions the application of either philosophy will produce the same or similar results. ${ }^{154}$

As a matter of law, however, the Commission was wrong. Discerning the appropriate purpose of sentencing has often been a critical decision for choosing between widely varying sentences. Judges select purposes quite differently with

152. See Freed \& Miller, supra note 104, at 297 (noting that "purposes of sentencing" were to play "central role" in formulating individual sentences and in drafting guidelines); Miller, supra note 28.

153. U.S.S.G., supra note 1 , ch. 1, pt. A, intro. 3.

154. Id. The Commission overlooked the fact, for example, that crime may be controlled either by rehabilitating an offender or by incapacitating him. Ordering an addict into a community drug rehabilitation program or imprisoning him for 10 years may equally reduce crime, but they are not considered similar sentences in the real world. 
respect to different crimes and different types of offenders. ${ }^{155}$ Kenneth Feinberg, who as Chief Counsel of the Senate Judiciary Committee was a primary author of the legislation creating the Commission, recently observed:

A strong argument can be made that, by ignoring the Congressional mandate to consider purposes, the Commission has failed to consider variables very relevant to the individually tailored sentence. In the absence of more explicit language from the Commission detailing the consideration given criminal justice purposes, courts would appear to be free to cite the abdication of Commission responsibility in this area. ${ }^{156}$

The Commission's decision to adopt an empirical approach effectively homogenized all cases at the sentencing stage. This decision is reflected in the Commission's omission of "purpose" from section 1B1.1, the "Application Instructions." Instead of providing guidance, the Commission by default leaves to each individual judge the twin duty: (1) to identify a purpose or set of purposes in each case, according to the judge's own standard or to ones developed by appellate courts; and (2) to fashion a sentence to promote those purposes.

The Commission's omission in no way invalidates the guidelines. It simply leaves to the courts the unguided task of carrying out Congress's purpose instructions in $\S 3553(\mathrm{a})(2)$. For example, a judge confronted by an offender who has committed a series of crimes of violence might invoke the key provision in $\S 3553(\mathrm{a})(2)(\mathrm{C})$ - "to protect the public from further crimes of the defendant"- to impose a longer prison sentence than prescribed by the applicable guideline.

Such a "departure" under $\S 3553$ (b) must be based on the Commission's inadequate consideration of the kind or degree of offender characteristics present in the case. A statement of reasons must explain how the offender's characteristics add up to a profile of dangerousness that goes beyond that of the typical person convicted of the same crime, and that requires an extended period of incapacitation in prison. By departing in this example, the judge might conclude that the Commission underestimated the incapacitative purpose of public protection to the degree needed in this case when it established its "heartland" range for the crime category.

In a separate case, the sentencing hearing might lead the judge to conclude that the missing element of purpose in the "Application Instructions," coupled

155. See, e.g., United States v. Valle, 929 F.2d 629, 632 (11th Cir.) (magnitude of upward departure was "appropriate and even necessary to insure respect for the law and, more specificaily, to see that our system of punishment retains its deterrent effect."); United States v. Lara-Velasquez, 919 F.2d 946 (5th Cir. 1990) (stating that primary purpose of sentencing is punishment but defendant's rehabilitative potential may be mitigating factor); Freed \& Miller, supra note 104; Miller, supra note 28, at 33-37.

156. Kenneth $\mathrm{R}$. Feinberg, The Federal Guidelines and the Underlying Purposes of Sentencing, 3 FED. SENTENCING REP. 326, 328 (1991). 
with the "sufficient, but not greater than necessary" criminal penalty standard set forth by Congress in $\S 3553$ (a), requires a sentence below the prison range. The judge might find that because the defendant, for whose crime the guideline sentence is imprisonment, possesses an unusual combination of characteristics clearly demonstrating that incapacitation is unnecessary, that the offender poses no danger to the public, and that deterrence, just punishment, and medical rehabilitation-pursuant to purpose subsections (A), (B), and (D) of $\S 3553(\mathrm{a})(2)$ - can best be served by a probation sentence conditioned on placement in a designated residential drug treatment facility, followed by home confinement, community service and a fine. ${ }^{157}$

Until the Commission acts to provide reasonable guidance with respect to the purposes of sentencing, judges will remain obligated to implement the purposes of $\S 3553(a)(2)$ on their own.

\section{c. Substantial Assistance}

A major escape route from the inflexibility of guideline sentences lies in the statutory and Commission provisions for substantial assistance discounts to offenders who aid in the investigation or prosecution of others. ${ }^{158}$ Policy statement 5K1.1 authorizes a downward departure of unlimited magnitude by a court on motion of the Assistant United States Attorney. This single policy statement covers two different kinds of substantial assistance situations.

First, in 18 U.S.C. $\S 3553(\mathrm{e})$, Congress expressly authorizes courts to sentence offenders below the minimum penalty in a mandatory sentencing statute, if the government files a motion to that effect. ${ }^{159}$ Section $5 \mathrm{~K} 1.1$ faithfully carries out that statutory instruction. Second, in 28 U.S.C. § 994(n), Congress instructs the Commission to assure that the guidelines reflect the "general appropriateness" of a lower sentence than would otherwise be imposed where the defendant rendered substantial assistance "in the investigation or prosecution of another person." ${ }^{\text {" } 60}$ Unlike $\S 3553(\mathrm{e})$, this provision is not limited to mandatory penalty cases and does not condition a reduced sentence on a prior government motion. The Commission has not complied with this instruction.

Rather than drafting a "guideline," the Commission wrote a "policy statement." Entirely on its own prerogative, it inserted the requirement of a government motion as a prerequisite to a judicial decision to reduce a nonmandatory

157. 18 U.S.C. $\S 3553$ (1988); see also United States v. Rodriguez, 724 F. Supp. 1118 (S.D.N.Y. 1989); Richard S. Frase, Defendant Amenability to Treatment or Probation as a Basis for Departure Under the Minnesota and Federal Sentencing Guidelines, 3 FED. SENTENCING REP. 328 (1991).

158. U.S.S.G., supra note $1, \S 5 \mathrm{~K} 1.1$.

159. 18 U.S.C. \& 3553(e) (1988).

160. 28 U.S.C. § 994(n) (1988). 
sentence. The Guidelines Manual does not explain either of these unauthorized deviations from the statutory instructions.

In 1990, the Commission wrote an introduction to chapter seven of the Guidelines Manual, defining for the first time its conception of the difference between guidelines and policy statements. Written in connection with probation revocation, it stated:

At the outset, the Commission faced a choice between promulgating guidelines or issuing advisory policy statements for the revocation of probation and supervised release. After considered debate and input from judges, probation officers, and prosecuting and defense attorneys, the Commission decided, for a variety of reasons, initially to issue policy statements. Not only was the policy statement option expressly authorized by statute, but this approach provided greater flexibility to both the Commission and the courts. Unlike guidelines, policy statements are not subject to the May 1 statutory deadline for submission to Congress, and the Commission believed that it would benefit from the additional time to consider complex issues relating to revocation guidelines provided by the policy statement option. Moreover, the Commission anticipates that, because of its greater flexibility, the policy statement option will provide better opportunities for evaluation by the courts and the Commission. ${ }^{161}$

This statement by the Sentencing Commission is fully consistent with the way Congress distinguished guidelines from policy statements. However, most appellate courts have rejected any downward departure where the defendant shows substantial assistance in a nonmandatory penalty statute case, but the government refuses to make a substantial assistance motion. ${ }^{162}$ One major difficulty with vesting exclusive power in the prosecutor to decide whether defendants are eligible or ineligible for downward departures is that there are

161. U.S.S.G., supra note 1, ch. 7, pt. A, intro. 3(a) (emphasis added). In United States v. Lee, No. 91-6079, 1992 WL 27639, at *2 (10th Cir. Feb. 19, 1992), the Tenth Circuit distinguished between the nonbinding effect of the chapter 7 policy statements and the binding effect of the $\$ 5 \mathrm{~K} 1.1$ policy statement dealing with substantial assistance. It apparently did so in the belief that $\S 5 \mathrm{~K} 1.1$ was derived exclusively from 18 U.S.C. $\$ 3553(\mathrm{e})$, which relates to mandatory minimum penalties. Id. The court overlooked the fact, not necessary to the decision in the Lee case, that $\$ 5 \mathrm{~K} 1.1$ is also derived from 28 U.S.C. \& 994(n), which authorizes neither a prosecutorial motion nor a policy statement, but does require a guideline allowing substantial assistance departures in cases arising under nonmandatory penalty statutes.

162. Recently, the Commission published a proposed amendment which, if adopted, would change this policy. See U.S. Sentencing Comm'n, Sentencing Guidelines and Policy Statements for Federal Courts: Notice, 57 Fed. Reg. 90, 112 (proposed Jan. 2, 1992). However, during the Sentencing Institute of the Second and Eighth Circuits on March 14, 1992, Commissioner Michael Gelacak expressed the view that the proposed amendment would not be accepted by the Commission. See supra note 123.

Some courts have distinguished between guidelines and policy statements. See, e.g., Lee, $1992 \mathrm{WL}$ 27639, at *4; United States v. Long, 936 F.2d 482, 483 (10th Cir.), cert. denied, 112 S. Ct. 662 (1991); United States v. Vargas, 925 F.2d 1260, 1267 (10th Cir. 1991); United States v. Kuntz, 908 F.2d 655, 657 (10th Cir. 1990). Others, however, have not. See, e.g., United States v. Ayers, 946 F.2d 1127, 1130 (5th Cir. 1991); United States v. Blackson, 940 F.2d 877, 893 (3d Cir.), cert. denied, 112 S. Ct. 611 (1991); United States v. Oliver, 931 F.2d 463, 465 (8th Cir. 1991); United States v. Pharr, 916 F.2d 129, 133 n.6 (3d Cir. 1990), cert. denied, 111 S. Ct. 2274 (1991); see also infra Part V.B.1. 
no visible standards to guide the prosecutor's exercise of discretion. Perhaps as a result of this unguided prosecutorial power to urge or preclude a substantial assistance departure, the Commission's 1990 annual report discloses very wide disparity among districts in the award of such departures, from a low of $0 \%$ in, for example, the District of New Hampshire, the District of Puerto Rico, and the Eastern Districts of Texas and Oklahoma; to highs of $13.3 \%$ in the District of Maine, $15.2 \%$ in the District of South Carolina, 22\% in the Eastern District of Pennsylvania, and $24.1 \%$ in the Northern District of Oklahoma. ${ }^{163}$

During the recent Sentencing Institute of the Second and Eighth Circuits, ${ }^{164}$ a number of district judges engaged Commission members in a plenary session dialogue on the subject of substantial assistance. They observed that 28 U.S.C. \& 994(n) did not authorize a prosecutorial motion requirement for substantial assistance departures; that section $5 \mathrm{~K} 1.1$ reversed prior practice under which district judges, not U.S. Attorneys, exercised discretion to decide whether or not to reduce a sentence based on defendant assistance; and that vesting power over such departures in the unregulated discretion of an AUSA, a nonneutral party, invited the very disparity that the SRA had sought to eliminate.

\section{d. Relevant Conduct}

The relevant conduct guideline, which has been called the "cornerstone of the federal sentencing guidelines," 165 undertakes the difficult task of guiding courts on a problem that has long troubled the factfinding process in criminal sentencing. The question is how far the sentencing judge may go in using adverse factual information about the crime, and other allegations against the offender, that have neither been acknowledged by the defendant nor proven in court beyond a reasonable doubt. ${ }^{166}$

Prior to guideline sentencing, there were few rules regarding the admissibility of information at the sentencing stage. In Williams v. New York, ${ }^{167}$ decided in 1949, the Supreme Court held that a sentencing court was free to use a wide array of information about the offender and alleged prior crimes, including

163. 1990 ANNUAL REPORT, supra note 15, app. C, tbl. C-5.

164. See supra notes $123,162$.

165. William W. Wilkins, Jr. \& John R. Steer, Relevant Conduct: The Cornerstone of the Federal Sentencing Guidelines, 41 S.C. L. REV. 495, 496 (1990).

166. See Williams v. New York, 337 U.S. 241 (1949) (holding due process not violated if sentencing judge considers defendant's prior criminal record without permitting witness confrontation on that subject). The dissent protested that the judge, in overnuling the jury's recommendation of a life sentence and imposing the death penalty, relied on "a probation report, consisting almost entirely of evidence that would have been inadmissible at the trial. Some, such as aliegations of prior crimes, was irrelevant. Much was incompetent as hearsay. All was damaging, and none was subject to scrutiny by the defendant." Id. at 253 (Murphy, J., dissenting).

167. Id. 
crimes never previously charged. This system became known as "real offense" sentencing.

The Williams decision was influenced by two considerations that no longer govern today. First, in a system without guidelines, any sentence within the statutory sentencing range was lawful. A judge, moreover, could impose an authorized sentence without giving reasons as to how it was selected. Information about prior crimes did not have to bear any particular relation to the sentence imposed. An offender with no prior record could receive the maximum sentence. An offender with several prior convictions or unadjudicated charges could receive the lowest authorized sentence. Except for issues of constitutional magnitude, there was no appellate review of sentences in most jurisdictions. Second, the prevailing philosophy of sentencing in 1949 was rehabilitation. The Court clearly wished to allow judges to resort to any information available, assess its relevance and reliability, and apply their own conception of an appropriate sanction. There was concern that imposing evidentiary rules on sentencing would exclude information that might otherwise serve a salutary purpose.

The Minnesota guidelines rejected real offense sentencing and instead established a conviction offense system on the rationale that due process would be offended if the government or the court were allowed to use unadjudicated crime information to enhance a guideline sentence. ${ }^{168}$ The U.S. Sentencing Commission took the opposite position for reasons spelled out in chapter one of the Guidelines Manual, and elaborated in law review articles by Commissioner Breyer in $1988^{169}$ and Chairman Wilkins in $1990 .^{170}$ They argued that conviction offense sentencing placed too much power in the hands of the prosecutor and deprived courts of too much discretion. They reasoned that real offense sentencing would permit the judge to determine which information was relevant, whereas conviction offense sentencing would hinge on prosecutorial decisions as to charges and guilty pleas. ${ }^{171}$

168. PARENT, supra note 7 , at $62-63,159-61$. Parent distinguishes between alleged offense and conviction offense sentencing. Others, intending the same distinction, call it real offense versus charge offense sentencing. According to Professor Michael Tonry, every sentencing commission in the United States, apart from the federal Commission, has opted for a charge offense system. Michael Tonry, Remarks at the Sentencing Institute for the Second and Eighth Circuits, Lexington, Ky. (Mar. 4, 1992); see also Michael Tonry, Mandatory Minimum Penalties and the U.S. Sentencing Commission's "Mandatory' Guidelines," 4 FED. SENTENCING REP. 129 (1991).

169. Breyer, supra note 44.

170. Wilkins \& Steer, supra note 165; Marc Miller \& Ronald Weich, The Relevant Conduct Controversy, 2 FED. SENTENCING REP. 150 (1989); see also Symposium, The Issue of Relevant Conduct, 2 FED. SENTENCING REP. 129-60 (1989).

171. Contrasting discussions about the soundness of Ninth Circuit decisions are found in comments by a prosecutor and a defense attorney who served as guest editors for an issue on "Turmoil Over Relevant Conduct in the Ninth Circuit." Compare Roger W. Haines, Jr., The Ninth Circuit's Undeclared War on "Real Offense" Factors and Relevant Conduct, 4 FED. SENTENCING REP. 191 (1992) with Judy Clarke, The Real Issue: Fair Plea Bargains, Not Relevant Conduct, 4 FED. SENTENCING REP. 194 (1992). 
The Commission's solution, embodied in section 1B1.3 of the Guidelines Manual, was a set of carefully drafted rules that allowed a court to consider information about certain kinds of alleged misconduct going beyond issues presented to the jury, acknowledged in the defendant's guilty plea, or stipulated to under guideline section 1B1.2. The public debate over this section has been substantial. The Ninth Circuit largely rejected the relevant conduct concept in a series of 1990-1991 appeals in plea-bargained cases. ${ }^{172}$ It and other courts have embraced relevant conduct for at least some purposes and incorporated a "preponderance of evidence" standard to assure reliability. ${ }^{173}$ Most lawyers, as well as ordinary citizens unfamiliar with the daily procedures of criminal law administration, are astonished to learn that a person in this society may be sentenced to prison on the basis of conduct of which a jury has acquitted him, or on the basis of charges that did not result in conviction.

The basic conceptual flaw in applying "relevant conduct" following a guilty plea is that, contrary to the Commission's rationale, it enhances rather than reduces the power of the prosecutor. Indeed, it allows a prosecutor to increase an offender's sentence more easily by dropping charges than by bringing them! The AUSA can secure a guilty plea on a reduced charge, only then to file with the sentencing judge alleged information that the defendant neither conceded nor stipulated to in plea negotiations. In jury conviction cases, the "relevant conduct" standard allows the AUSA to introduce evidence of another crime at the sentencing stage that was withheld from trial because the AUSA could not prove it "beyond a reasonable doubt."

Relevant conduct is becoming a central issue in plea negotiations, as defense attorneys slowly gain awareness of the magnitude of sentence exposure that a seemingly reduced guilty plea can convey. It is thus becoming a source of increasingly intense bargaining and compromise when the AUSA does not wish to go to trial, and the defender wants to limit sentencing exposure. These compromises provide a significant arena for attorney discretion and presentencing guideline manipulation. They exacerbate discrimination between wellrepresented defendants, for whom a careful bargain fixes the parameters for a predictable sentence, and less fortunate defendants who, inadequately represented, enter an untutored plea unaware of the relevant conduct consequences that may follow.

Ironically, the relevant conduct guideline reduces visibility and candor in sentencing. It signifies that the facts presented to the judge or jury do not place guideline boundaries on the sentence, and that the rules governing how far

172. See, e.g., United States v. Fine, 946 F.2d 650 (9th Cir. 1991); United States v. Faulkner, 934 F.2d 190 (9th Cir. 1991); United States v. Brady, 928 F.2d 844 (9th Cir. 1991); United States v. Castro-Cervantes, 927 F.2d 1079 (9th Cir. 1990).

173. United States v. Ebbole, 917 F.2d 1495 (7th Cir. 1990) (holding that application of $\S 1 B 1.3$ using preponderance of evidence standard did not deny defendant due process of law); United States v. Guerra, 888 F.2d 247, 251 (2d Cir. 1989) (stating "preponderance of the evidence standard satisfies the requisite due process in determining relevant conduct" under guidelines). 
relevant conduct may be stretched are in fact leading sophisticated practitioners to bargain over how much unadjudicated information will be withheld from the court. ${ }^{174}$

Whatever one may think of adding "relevant" criminal allegations to adjudicated criminal conduct at the time of sentencing, the outcome is a disaster for guidelines that purport to reduce unwarranted disparity. District judges, prosecutors, defenders, and probation officers are today demonstrating widely different attitudes and practices respecting relevant conduct within and across districts. The bottom line, as suggested earlier, is that disparity resulting from section 1B1.3 is flourishing in the federal courts, and the longer the Commission hews to its present course, the more courts can be expected to diverge from that course and disagree among themselves as to its fairness.

\section{Offender Characteristics: "Not Ordinarily Relevant"}

Perhaps no provisions in the guidelines evoke more dismay from the federal judiciary, the probation service, and the bar than the policy statements assembled in chapter $5 \mathrm{H}$, entitled "Specific Offender Characteristics." These provisions declare many personal characteristics of an offender to be "not ordinarily relevant" to sentencing outside the applicable guideline range. ${ }^{175}$ As indicated below, these $5 \mathrm{H}$ policy statements squarely conflict with guideline section $1 \mathrm{~B} 1.4$ and are inconsistent with $\S \S 3553(\mathrm{a})$ and 3661 of title 18.

In Congress' title 18 instructions to judges, the first step listed for determining the particular sentence to impose under $\$ 3553(a)(1)$ is an inquiry into the nature and circumstances of the offense and "the history and characteristics of the offender." And in $\S 3661$, recodifying former $\S 3557$, Congress made it clear that past practice regarding judicial consideration of personal information about the defendant was to continue:

No limitation shall be placed on the information concerning the background, character, and conduct of a person convicted of an offense which a court of the United States may receive and consider for the purpose of imposing an appropriate sentence. ${ }^{176}$

In a second set of provisions regarding offender characteristics, in title 28, Congress set two tasks for the Commission. First, in § 994(d), it instructed the

174. As indicated earlier, the probation officer may call the court's attention to information that appears to have been stipulated away. In some cases, courts hold hearings to inquire into the reasons why a stipulation has not included certain information.

175. For discussion of offender characteristics in the SRA's legislative history, see, e.g., S. REP. No. 225, supra note 9, at 168-75, reprinted in 1984 U.S.C.C.A.N. at 3351-58. See also Freed \& Miller, supra note 10. In November 1991, the Commission expanded its chapter $5 \mathrm{H}$ list of factors "not ordinarily relevant" to guideline departures "to include military, civic, charitable, or public service; employment-related contributions; and a record of prior good works." U.S.S.C. IMPACT REPORT, supra note 2, at 23.

176. 18 U.S.C. $\$ 3661$ (1988). 
Commission to consider whether eleven enumerated "matters" with respect to a defendant "have any relevance to the nature, extent, place of service, or other incidents of an appropriate sentence, and shall take them into account only to the extent that they do have relevance."177 The factors listed were (1) age, (2) education, (3) vocational skills, (4) mental and emotional condition, (5) physical condition including drug dependence, (6) previous employment record, (7) family ties and responsibilities, (8) community ties, (9) role in the offense, (10) criminal history, and (11) dependence on criminal activity for a livelihood. The first eight factors are personal characteristics; the last three are criminal characteristics of the offender.

Second, in § 994(e), Congress instructed the Commission to assure that the guidelines and policy statements, in recommending a term of imprisonment or the length of such a term, ${ }^{178}$ " reflect the general inappropriateness of considering the education, vocational skills, employment record, family ties and responsibilities, and community ties of the defendant."179 (This listing excludes three personal characteristics found in $\S 994(\mathrm{~d})$-age, mental and emotional condition, and physical condition.)

Congress' instructions to judges in 18 U.S.C. § 3553(a) and § 3661 seemed inconsistent on their face with its title 28 instructions to the Commission. In title 18, Congress made it clear that judges were to be unrestricted in their consideration of information about the history and characteristics of the offender. On the other hand, in 28 U.S.C. § 994(d) Congress seemed to make the Commission the assessor of relevance. And 28 U.S.C. § 994(e) declared Congress' policy that five personal characteristics were "generally inappropriate" in determining prison sentences (but not probation). How can these provisions be reconciled?

The Guidelines Manual does not recognize or respond to this question. Nowhere does it face up to the mandate of 28 U.S.C. $\$ 991$ (a) that the guidelines and policy statements be consistent with all provisions of titles 18 and 28 . In its original guidelines the Commission did not even acknowledge 18 U.S.C. $\S 3661$. But effective January 15, 1988, the Commission incorporated the inconsistencies directly into the Guidelines Manual. ${ }^{180}$ In compliance with $\S 3661$, it promulgated guideline 1B1.4, as follows:

In determining the sentence to be imposed within the guideline range, or whether a departure from the guideline is warranted, the court

177. 28 U.S.C. $\$ 994$ (d) (1988).

178. To interpret this language consistently with the legislative history, one might say that Congress was enumerating characteristics that connoted a rehabilitative sentencing purpose. Since 28 U.S.C. $\$ 994(\mathrm{k})$ (1988) instructs the Commission to assure the inappropriateness of imprisoning offenders in order to carry out the purpose of rehabilitating them, $\$ 994(\mathrm{e})$ (1988) cautions against using the listed personal characteristics to guide the sentencer toward a prison sentence, or to determine the length of a prison term. It does not inhibit a court from using the same characteristics to formulate a sentence of probation.

179. 28 U.S.C. $\$ 994(\mathrm{e})$.

180. U.S.S.G., supra note 1 , app. C, at 4-5. 
may consider, without limitation, any information concerning the background, character and conduct of the defendant, unless otherwise prohibited by law. ${ }^{181}$

In its accompanying commentary, the Commission's explanation only compounded the confusion with the following four statements: (1) that the guideline "distinguishes between factors that determine the applicable guideline range (section 1B1.3) and information that a court may consider in imposing sentence within that range"; (2) that a "court is not precluded from considering information that the guidelines do not take into account"; (3) that "information that does not enter into the determination of the applicable guideline sentencing range may be considered in determining whether and to what extent to depart from the guidelines"; and (4) that "some policy statements do, however, express a Commission policy that certain factors should not be considered for any purpose, or should be considered only for limited purposes."182

It is difficult to understand why the three judges on the Commission were willing to abandon past practice and override the offender characteristics provisions addressed to judges in title 18. Judges everywhere confront the offender at sentencing, often after observing him in pretrial or trial proceedings. They read the presentence investigation report to learn about his history and characteristics. They listen to what the person and his attorney say in mitigation, and to what the AUSA presents about voluntary disclosure, remorse, or bad character, about substantial assistance in the prosecution of others, or about future dangerousness. Despite rhetoric to the contrary, most judges in most courts sentence by reference to the offender, not just to the crime.

In the end, the Commission chose to acknowledge the relevance only of a person's criminal characteristics, and tallied them up arithmetically in its matrix categories I, II, III, IV, V, and VI. ${ }^{183}$ It offered no reasons supporting its conclusion that the eight enumerated personal characteristics were ordinarily irrelevant. ${ }^{184}$ It wrote no commentary to present its research or to weigh the wisdom and drawbacks of a different policy. The Guidelines Manual's designation of all chapter $5 \mathrm{H}$ material as policy statements symbolizes the uncertainty of the decision. ${ }^{185}$

Perhaps the Commission could not determine how to convert personal characteristics into point scores in an arithmetically based system. Consistent

181. Id. $\& 1 \mathrm{~B} 1.4$ (emphasis added). The Guidelines Manual does not explain the authority for adding the words "unless otherwise prohibited by law," but it probably refers to the last sentence of 28 U.S.C. \$ 994(d): "The Commission shall assure that the guidelines and policy statements are entirely neutral as to the race, sex, national origin, creed, and socioeconomic status of the offenders."

182. U.S.S.G., supra note $1, \S 1 \mathrm{~B} 1.4 \mathrm{cmt}$. (citing chapter $5 \mathrm{H}$ ).

183. See id. \$§ 3B1.1-.2 (role in the offense); id. §§ 4A1.1-.3 (criminal history); id. §§ 4B1.1-.4 (criminal livelihood); $c f$. id. ch. 5 , pt. A (sentencing table).

184. See id. $\$ \S 5 \mathrm{H1} .1$-.11 (age, education, vocational skills, mental and emotional conditions, physical condition, employment record, family and community ties, are "not ordinarily relevant").

185. See infra Part V.B.1. 
with the flexible and evolutionary spirit of the Introduction to its Guidelines Manual, it could have encouraged judges to spell out their reasons when they enhanced or diminished sentences. Assembling such statements for a year or two would have provided a data base of judicial reasoning. Furthermore, analysis of the reasons might have enabled the Commission to draft and explain a less inconsistent, more satisfactory set of policies. ${ }^{186}$

The Commission's failure to reconcile the inconsistent provisions in the statute and the inconsistent language in its own Guidelines Manual, and its inability to affirmatively guide the relevance of personal characteristics, has troubled the courts. ${ }^{187}$ As we will see in Part IV, these troublesome rules are causing turbulence in the probation service and among prosecutors and judges, producing disparate sentences instead of the reasonable consistency for which the guideline concept was designed.

\section{District COURT SENTENCING: RIGID GUIDELINES IN A DISCRETIONARY PROCESS}

The guideline development process included much empirical study of presentence reports written by probation officers, but little research into the decisionmaking processes of judges and practitioners. Instead of bringing to light shared principles in the administration of sentencing justice, the Commission's research failed to sensitize it to the values and norms of the judges for whom it was about to "legislate." As a result, it is not surprising that the Guidelines Manual has had an impact on courts quite different from that intended by the Commission: rather than increasing sentencing visibility and reducing "unwarranted" disparity, the guidelines have tended to reduce visibility and to produce "intentional" disparity. ${ }^{188}$

A brief review of the history of interactions between the Commission and the federal judiciary in Section A below sets the stage for analysis in Section $\mathrm{B}$ of the reasons for the increasing resistance and persistent disparity five years after the guidelines began.

186. The Commission wisely acknowledged in its initial Guidelines Manual that it was "difficult to prescribe a single set of guidelines that encompasses the vast range of human conduct potentially relevant to a sentencing decision." U.S.S.G., supra note 1, ch. 1, pt. A, intro. 4(b). Likewise, it stated that "By monitoring when courts depart .... and by analyzing their stated reasons for doing so and court decisions with reference thereto, the Commission, over time, will be able to refine the guidelines to specify more precisely when departures should and should not be permitted." Id.

187. Cf. Freed \& Miller, supra note 10 , at 235 ("This sense of judicial powerlessness to deviate from Judicial Branch administrative regulations strikes us as a fundamental error.").

188. U.S.S.C. IMPACT REPORT, supra note 2, at 114 tbl. 29; see also Schulhofer \& Nagel, supra note 17 , at 245 (finding that by agreeing to plead guilty to lesser offense severity level, defendants may reduce amount of time served by $25-35 \%$ ). 


\section{A. Judicial Reactions to the Commission}

District judges sensed very early that the new system would deviate conceptually from previous sentencing norms. They initially expressed their opposition in hearings in the fall of 1986, when the Commission began to receive comment on early drafts. ${ }^{189}$ When the Commission submitted its third draft to Congress in April 1987, substantial judicial sentiment favored congressional action to suspend the imposition of guidelines pending full legislative hearings. Despite widespread support for that view by such groups as the Judicial Conference of the United States and the American Bar Association, Congress did not act, and the guidelines became law without legislative modification. ${ }^{190}$

The next stage for protest occurred in the courts. By mid-1988, a number of lawsuits challenged the guidelines as unconstitutional. Some district courts held unprecedented en banc hearings to receive arguments from the Department of Justice and the Commission, both of which supported constitutionality, though on different theories, and from defense attorneys, who argued that the Commission and its guidelines were unconstitutional. Within a year, nearly twohundred judges had written or concurred in decisions holding the new system invalid. ${ }^{191}$ In January 1989, the Supreme Court, by an eight-to-one vote, sustained the validity of both the SRA and the Commission in Mistretta $v$. United States. ${ }^{192}$

Settling the legal issue, however, did not pacify the courts. Experienced as well as recently appointed judges, liberals and conservatives, and former prosecutors as well as former private attorneys persisted in criticizing the Commission and the guidelines. ${ }^{193}$ In April 1990 the Federal Courts Study Committee published its final report, containing a chapter sharply critical of the guidelines. ${ }^{194}$ It reported that a survey of 270 witnesses found 266 against and four in favor of the guidelines. The detractors all were judges; the four

189. See, e.g., Regional Public Hearing Before the United States Sentencing Commission, Denver, Colo. 211 (1986) (testimony of Chief Judge Clarence Brimmer, D. Wyo.); Regional Public Hearing Before the United States Sentencing Commission, Chicago, Ill. 118 (1986) (testimony of Judge Michael Mihm, C.D. III.); Regional Public Hearing Before the United States Sentencing Commission, New York, N.Y. 33-34 (1986) (testimony of Judge Jack Weinstein, S.D.N.Y.).

190. The SRA provided that if Congress did not act within six months of the date it received the Commission's proposed guidelines, those guidelines would become law. Pub. L. No. 98-473, § 235, 98 Stat. 1987, 2031, reprinted in 18 U.S.C. § 3551 note (1988).

191. 1989 ANNUAL REPORT, supra note 50, at 11 (reporting 200 judges found Commission's guidelines unconstitutional, while 120 found them constitutional). But see Gubiensio-Ortiz v. Kanahele, 857 F.2d 1245 (9th Cir. 1988) (holding that statute establishing Commission violated separation of powers doctrine). The Ninth Circuit was the only appellate court to find the guidelines unconstitutional.

192. 488 U.S. 361 (1989).

193. See, e.g., Post-Mistretta Forum: How Can Guideline Sentencing Be Improved?, 1 FED. SENTENCING REP. 357-76 (1989).

194. FCSC REPORT, supra note 10 , at 133-44. 
supporters were three Commissioners and Attorney General Richard Thornburgh. ${ }^{195}$

The concerns of district judges centered on discrepancies between guideline concepts and outcomes, on one hand, and contemporary norms of sentencing and fair process on the other. They objected to the Guidelines Manual's complexity and to the Commission's effort to micromanage the judiciary. They spoke as though the third branch had become the victim of a hostile takeover. Their message was clear, in the press, in judicial conferences, from the bench at the time of sentencing, and in testimony before the Commission and Congress. ${ }^{196}$

One might have expected the Commission to respond by reducing the inflexibility and severity of the guidelines. Instead, its amendment process rejected virtually all of the judiciary's suggestions. ${ }^{197}$ Tightening the guidelines and adding new amendments every year, the Commission seemed determined to show how tough an administrative agency can be in the face of consumer opposition, even when the consumers are Article III judges.

\section{B. Process Responses by Four Sentencers}

Outspoken condemnation was not the only professional response to the guidelines. It soon became clear that a variety of actors, including judges, retained power and discretion over sentencing that guidelines could not control. To the extent that judges were constrained, discretion could be exercised by others.

This section illustrates how judges, prosecutors, defense attorneys, and probation officers, among others, ${ }^{198}$ have reacted in individual cases to fundamental alterations in the traditional sentencing process. In an important sense, each of these professionals exercises sufficient discretion to be considered a "sentencer."

To understand the actions of these sentencers, the reader should know something about the range of discretionary decisions various actors can make under the federal guidelines. Until recently, the Commission described sentences either as in "compliance" with the guidelines or as explicit "departures" from

195. Id. at 142.

196. See e.g., Cabranes, supra note 10; Public Hearing, supra note 10.

197. See Fred W. Bennett, A Direct Participant's Perspective on the Guideline Amendment Process, 3 FED. SENTENCING REP. 148 (1990) (discussing amendment process and possible means of improvement); Thomas W. Hillier III, The Commission's Departure From an Evolutionary Amendment Process, 4 FED. SENTENCING REP. 45 (1991) (criticizing amendment process); $c f$. Statement of Thomas Hillier on behalf of Federal Public and Community Defenders, in 2 FED. SENTENCNG REP. 224 (1990) (criticizing disparity and unfaimess produced by guidelines).

198. The court of appeals is also a "sentencer"; Part V, infra, discusses its role in connection with the companion duty to serve as a reviewer of guidelines. 
them. 199 "Compliance" meant that judges were following the "Application Instructions" in section 1B1.1 and a host of other provisions to determine the appropriate sentencing range for an offender. These included:

(1) the chapter 1 guideline on relevant conduct; ${ }^{200}$

(2) the chapter 2 base offense calculations and specific offense characteristics, ${ }^{201}$

(3) the chapter 3 array of guideline adjustments; ${ }^{202}$

(4) the chapter 4 criminal history guidelines, and the escape provision on "adequacy" of criminal history set forth in policy statement $4 \mathrm{~A} 1.3 ;^{203}$

(5) the chapter $5 \mathrm{H}$ and $5 \mathrm{~K}$ policy statements governing offender characteristics and departures; ${ }^{204}$ and

(6) the chapter 6 policy statements on plea bargaining. ${ }^{205}$

"Departure" occurred whenever a judge sentenced outside the calculated range, regardless of the reasons given.

The distinction between compliance and departure was a false dichotomy, manufactured by the Commission to deter judges from sentencing outside the prescribed ranges. It understated the considerable opportunities for discretion available to participants in the sentencing process. It also underestimated the extent to which two officials, reading the same guidelines in the same case, can and do interpret the same guidelines differently and impose different "guideline sentences."206 Finally, it failed to capture the distinction between formal departures and informal action by prosecutors and defense attorneys when they negotiate guideline avoidance.

\section{Probation Officers}

Looking more closely at the role each sentencer plays in the application of guidelines to an offender, the judge usually turns first to the probation officer. The presentence report, prepared by the probation officer, is expected to set forth undisputed facts and all guideline calculations. It alerts the judge

199. See 1989 ANNUAL REPORT, supra note 50, at 2; Tonry, supra note 6 (discussing Commission's data on compliance rates); Paul K. Martin, Response to Michael Tonry, 2 FED. SENTENCING REP. 158 (1989). Judges were outraged by the Commission's characterization, in its 1989 annual report, that departures represented "noncompliance" with the guidelines. They argued, appropriately, that 18 U.S.C. \& 3553(b) (1988), and chapter 5K of the Guidelines Manual explicitly authorized departures. In the 1990 annual report, issued in the summer of 1991, the Commission was careful to avoid repeating its mistake.

200. U.S.S.G., supra note $1, \S 1 B 1.3$.

201. Id. $\$ \$ 2 A 1.1-2 \times 5.1$.

202. Id. \$\$ 3B1.1-3E1.1.

203. Id. \& $\$ 4 \mathrm{~A} 1.1-4 \mathrm{~B} 1.4$.

204. Id. $\$ \S 5 \mathrm{H} 1.1-.11,5 \mathrm{~K} 1.1-5 \mathrm{~K} 2.16$.

205. Id. $\$ \$ 6 \mathrm{~B} 1.1-.4$.

206. Each chapter in the Guidelines Manual, despite detailed instructions often set forth in mandatory language, affords wide leeway for different interpretations by each judge, AUSA, defense attorney, and probation officer. 
to factual disputes between the AUSA and the defense attorney, indicates a proposed guideline sentence or range, and, optionally, comments on the appropriateness of a departure. In addition, the presentence report contains the probation officer's confidential sentence recommendation. ${ }^{207}$

Probation officers have been criticized for being "guardians of the guidelines" and for taking the government's side in factfinding under the guidelines. ${ }^{208}$ They in turn have criticized both the Commission, for excessively complex and inflexible guidelines, and the courts of appeals, for conflicting and confusing decisions. ${ }^{209}$

The published views of probation officers demonstrate that no single opinion dominates the U.S. Probation Service regarding the desirability of the guidelines. ${ }^{210}$ Some officers evince pro-law enforcement leanings; others have pro-social work leanings. ${ }^{211}$ There are also differing attitudes about the desirability of departures. ${ }^{212}$ Probation officers often express dissatisfaction with the extent to which government and defense attorneys stipulate to lesser facts than a defendant's crimes or relevant conduct warrant. ${ }^{213}$ Officers sometimes are dismayed when judges order them to delete from presentence reports factual statements that are inconsistent with the sentence imposed. ${ }^{214}$

The Probation Service has many members who are highly regarded in their courts for service prior to the guidelines. During those years, probation officers devoted substantial time to gathering information and gaining insight into the offender's personal history. They assessed the offender as a whole person, examining his criminal history, community reputation, childhood, employment record, adult achievements, substance abuse problems and efforts to break such habits, and rehabilitative progress. They tried to distinguish between young offenders bent on building criminal careers and others who seemed about to turn a corner, settle down, and get a job. They supervised cases in which probation accompanied by community penalties, such as home confinement,

207. FED. R. CRIM. P. 32(c).

208. See Judy Clarke, Ruminations on Restrepo, 2 FED. SENTENCING REP. 135, 135 (1989) (discussing whether federal probation officers should continue to have role of interpreting law); Charlie E. Vamon, Response to Judy Clarke, 2 FED. SENTENCING REP. 202 (1989) (responding that probation officers have no discretion in recommending sentences); Judy Clarke, The Sentencing Guidelines: What a Mess, FED. PROBATION, Dec. 1991, at 45, 47. See generally Probation Officers and the Guidelines, 4 FED. SENTENCNG REP. $61-120$ (1991).

209. See, e.g., Bill Barrett, Probation Officers and the Beast, 4 FED. SENTENCDNG REP. 106, 107-08 (1991); Charlie E. Vamon, The Role of the Probation Officer in the Guideline System, 4 FED. SENTENCWG REP. 64-65 (1991).

210. For illustrations of a wide range of probation officer attitudes and role interpretations, see the collection of essays in Probation Officers and the Guidelines, supra note 208, at 61-120.

211. Id. 3 (1991).

212. Tony Garoppolo, Confusion and Distortion in the Federal Sentencing Process, 27 CRIM. L. BULL.

213. See, e.g., Natali, supra note 10, at 103 ("Subtle and creative forces began to short-circuit the whole process of guideline sentencing. Attorneys for the defense and the government found new ways to ply their old trade with plea bargains . . . in all shapes and sizes . . . stipulations seemed to be fiction writings, when compared with the known facts of the cases they attempted to address.").

214. See Barrett, supra note 209, at 107; Varnon, supra note 209, at 63-64. 
community service, or drug treatment, worked well, and other cases in which probationers committed new crimes.

Today, many probation officers and the judges they serve remain confident of the value of professional judgments and individual insights in controlling crime and treating offenders. They believe that individual judgments should continue to play an integral role in the sentencing process. To these professionals, boxes in a guidelines matrix cannot substitute for the personal assessments that probation officers and judges have been making for years.

Many new probation officers, on the other hand, have only come on duty since the guidelines' implementation. Newcomers often have little tradition to fall back on. Some are powerfully influenced by Commission training sessions. Others may be persuaded, by the attitudes of their chiefs, colleagues, or judges, to use the guidelines flexibly. Loyalties divided between new guideline teachings and older justice system traditions create tensions in the probation service and suggest one reason, among many, why different officers approach guideline assignments with different attitudes and arrive at different calculations and recommendations in similar cases.

Writings, speeches, and personal conversations with probation officers confirm that the guidelines have given the Probation Service a highly visible and pivotal role in the formation of sentences. Considerable variation exists in the ways officers write reports to shape ultimate sentences, and in the extent to which judges rely on the probation officer or review presentence investigations and guidelines calculations from scratch. Under such circumstances, the interaction between probation officer and judicial discretion inevitably creates countless opportunities for sentence disparity.

\section{Prosecutors}

Discretionary decisions of Assistant U.S. Attorneys, both as to charges and as to factual allegations, can powerfully expand or limit the judge's ambit for sentencing. One key category is "relevant conduct" under guideline 1B1.3. Such conduct enhances sentences based on information concerning the weight of drugs, amount of money, or possession of guns. It may also include alleged criminal conduct or aggravating aspects of crimes of which the defendant escaped conviction, or which he did not contemplate in his guilty plea. A prosecutor's options for including or excluding information can drastically influence the sentence range, and different prosecutors make different decisions in similar cases.

By adopting "mandatory guidelines" with many of the same attributes found in mandatory penalty statutes, ${ }^{215}$ the Commission has provoked the same sorts of evasion and nullification practices among prosecutors that it detailed it in

215. See Tonry, supra note 168. 
its report on those statutes. ${ }^{216}$ If an AUSA sympathetically perceives the judge as handcuffed in the effort to formulate a proportionate sentence in a low-level drug or gun case, the AUSA can lend a hand. She may drop a charge, or stipulate to the probability of a reduced quantity of drugs or an unloaded gun under the relevant conduct guideline. She may signify an intention not to appeal if the judge departs downward, or she may make a motion for a substantial assistance departure to enable the judge to sentence below the guideline range without fear of reversal. ${ }^{217}$

The prosecutor's ability to exercise compensating discretion in these respects may fall well within the policies of the Department of Justice ${ }^{218}$ and the past practices of the justice system. If called to account, the AUSA may, for example, cite the dubious provability of a larger amount of drugs, a lack of credible evidence that the gun was loaded with real bullets, or a heavy caseload of higher priority crimes that would suffer if this minor case were compelled to go to trial. ${ }^{219}$

Disparity quickly enters into the sentencing process when one AUSA readily makes these adjustments in prosecuting what, in her district, constitutes a low-level drug case, while an AUSA in another district, where drug trafficking and selling are rare, may press for the highest penalty range the guidelines will allow. ${ }^{220}$ Both discretionary actions may comply with Justice Department guidelines, but the resulting disparity is substantially invisible, largely immune from criticism, and beyond judicial review.

\section{Defense Attorneys}

Federal public defenders and private defense attorneys have less formal power over the disposition of their cases than do prosecutors. The defendant, not the attorney, makes the decision on plea or trial, on cooperating with the government, and on whether to appeal the ultimate conviction and sentence. Nevertheless, the defense attorney plays a key role in resolving the case and shaping the sentence.

Defense attorneys vary widely in their talents, zeal, understanding of the guidelines, knowledge of sentencing alternatives, and preparation and advocacy at sentencing. ${ }^{221}$ As a result, some defendants have a significantly better chance than others to lessen their penalty. The better lawyers succeed more

216. See MANDATORY MINMUM PENALTIES REPORT, supra note 4.

217. See U.S.S.G., supra note $1, \S 5 \mathrm{~K} 1.1$ (substantial assistance to authorities).

218. See Richard Thomburgh, United States Department of Justice March 13, 1989 Plea Policy for Federal Prosecutors, 1 FED. SENTENCING REP. 421 (1989).

219. Goodwin, supra note 133; Robert S. Mueller III, Mandatory Minimum Sentencing, 4 FED. SENTENCING REP. 230, 231 (1992).

220. See Memorandum from Attorney General William P. Barr to Federal Prosecutors 1 (Jan. 31, 1992) (on file with author) (describing "Project Triggerlock," in which Attomey General ordered federal prosecutors to seek upward departures in cases involving semiautomatic weapons and/or gang-related crime).

221. U.S.S.C. IMPACT REPORT, supra note 2, tbls. 21-22. 
often in avoiding indictment in the first place, in negotiating a reduction in the severity and number of charges, in presenting a more effective argument at sentencing, and in obtaining a less onerous outcome. ${ }^{222}$

Discrepancies in attorney talent and competence do not constitute disparity or disproportionality in a legally cognizable sense. So long as defense representation does not fall to the level of constitutionally ineffective assistance of counsel, defendants who receive worse sentences are deemed to have gotten all they deserve. ${ }^{223}$ Still, differences in the quality of representation account for a substantial share of sentencing variation, both prior to and under the guidelines. 224

To the extent that the guidelines strip judges of sentencing discretion, each defendant must place a premium on his attorney's ability to negotiate a desirable disposition with the prosecutor. Paradoxically, strict appellate enforcement of the guidelines, creating trial court reluctance to depart downward, often means that the defense attorney is more likely to achieve a lighter sentence through bargaining with the AUSA than by proceeding in accordance with the guidelines. 25

\section{Judges}

Before the judge faces the question of whether to impose the guideline sentence or to depart, she must first determine what it means to "comply" in light of the various findings and calculations outlined above. ${ }^{226}$ She must resolve issues identified in the presentence report - the factual and interpretative questions on which the parties could not agree, or on which the AUSA and the defender are in accord but the probation officer is not. Next, the judge may want to know the bottom line, for instance: what sentence will the guidelines permit if I find that the defendant possessed only forty-nine kilograms of cocaine, ${ }^{227}$ if I rule against the obstruction of justice charge, ${ }^{228}$ or if I determine that the defendant had a "minimal" rather than "minor" role in the offense? ${ }^{229}$ Finally, the judge must make a decision. It may be complicated

222. See generally KENNETH MANN, DEFENDING WHTTE-COLlAR CRIME: A PORTRAIT OF ATTORNEYS AT WORK (1985).

223. See, e.g., United States v. Pregler, 925 F.2d 268 (8th Cir. 1991); United States v. Garcia, 909 F.2d 1346 (9th Cir. 1990) (erroneous prediction by counsel concerning sentencing does not entitle defendant to challenge guilty plea).

224. See U.S.S.C. IMPACT REPORT, supra note 2, at 128-29 (defense counsel are participants least familiar with guidelines).

225. Letter from Michael G. Katz, Federal Public Defender, D. Colo., to Ilene H. Nagel, U.S. Sentencing Commissioner (Feb. 21, 1990), in 2 FED. SENTENCING REP. 229 (1990).

226. See supra notes 199-205 and accompanying text.

227. See U.S.S.G., supra note $1, \S 2 \mathrm{D} 2.1(\mathrm{~b})(1)$ (defendant convicted of possessing more than five grams of cocaine sentenced according to $\S 2 \mathrm{Dl}$.1, as if convicted of intending to distribute it); $i d$. $\$ 2 \mathrm{D} 1.1(\mathrm{c})(4)$ (between 50 and 150 kilograms of cocaine earns defendant level 36 sentence).

228. Id. $\$ 3 \mathrm{Cl} .1$ (obstruction of justice increases defendant's sentence).

229. Id. \$3B 1.2 (more mitigating to have had "minimal" than "minor" role). 
or comparatively simple, depending on whether she wishes to apply her experienced sense of the "usual" sentence in this sort of case, ${ }^{230}$ or whether she wishes mechanically to follow the probation officer's guideline calculations.

In many cases, perhaps a majority, the straight guideline sentence falls within the judge's sense of justice, and there is little problem resolving a guideline/justice issue. When this is not the case, however, the judge has a three-way choice:

(1) She may decide to comply with the guidelines in every respect. She may do so in the belief that the guidelines represent the architecture of a new system, different and better than the indeterminate pre-1987 system, and that it is preferable for judges to defer to uniform rules rather than to try to individualize each sentence. ${ }^{231}$

(2) She may decide to challenge the system openly. Biting the bullet, she may believe that departures are vital to the health of the system, ${ }^{232}$ that all sentencing decisions should be up front, that the Commission "inadequately considered" the degree to which an aggravating or mitigating factor is present in this case, and that she should take time to spell out her reasons for this sentence and not be concerned about the possibility of reversal on appeal.

(3) She may decide to avoid the formal system. She may choose to accept the plea negotiated by the parties, ${ }^{233}$ despite the probation officer's disagreement, believing that the parties' result is fairer than that required by the guidelines. She may take this quiet, less visible path to preclude reversal or to avoid having to write a careful statement of reasons or sentencing opinion with an uncertain fate. Or she may decide to depart on the record knowing that the AUSA and the defendant have agreed to waive appeal, thereby immunizing the sentence from review. ${ }^{234}$

When the gap between a guideline sentence and a just sentence is small, most judges are likely to choose the first option and follow the guideline, for the norm of courts is to follow the rules. As the gap between the Commission's guidelines and a judge's concept of just punishment widens, the degree of disrespect, noncompliance, and disparity is bound to increase, and the judge

230. The SRA's transformation from an indeterminate system, allowing parole release after defendants had served one-third (and sometimes less) of a prison sentence, to a determinate system in which defendants must serve close to the full sentence, requires judges to perform mental arithmetic and parole guesswork in order to compare a guideline sentence with the "usual" pre-guidelines sentence.

231. See, e.g., Kleinfeld, supra note 10 , at 16.

232. See, e.g., Vincent L. Broderick, Foreword, FED. PROBATION, Dec. 1991.

233. William Stafford, Settling Sentencing Facts at the Guilty Plea Hearing: A Time-Saver for the Trial Court, 3 FED. SENTENCING REP. 214 (1991); see also Nagel \& Schulhofer, supra note 2 (manuscript at 82-12 to 82-14) (noting judges complicit in charge-reduction plea agreements, even though guidelines require them to reject agreements that do not reflect adequately seriousness of actual offense, however, explaining complicity as resulting from "micro," as opposed to national policy, perspective on sentencing).

234. Cf. Roger W. Haines, Waiver of the Right to Appeal Under the Federal Sentencing Guidelines, 3 FED. SENTENCNG REP. 227 (1991) (arguing that exclusion in plea negotiation of right to appeal sentence is proper). 
may more often choose the second option, formal challenge, or the third option, informal avoidance. When the gap becomes very wide, more and more decisionmakers - prosecutors, probation officers, and judges ${ }^{235}$-will opt for the just sentence because they are all sworn to do justice. In these situations, still more discretionary decisions in similar cases will land on the avoidance side of the guideline versus justice dispute, resulting in greater disparity.

One may question whether this sort of disparity is warranted or "unwarranted" within the meaning of the SRA. It is both. Those who sense that justice requires them to avoid an unreasonable guideline sentence in a particular case are warranted in seeking a just sentence. "Fairness" is a primary goal of the SRA, ${ }^{236}$ and the sentencer who conscientiously believes that the guideline sentence is unfair might also believe that it is more likely to produce injustice. But since many sentencers consider the guidelines to be the equivalent of a statute and thus must be enforced without regard to one's personal view of justice, the resulting disparity, which the rigid guidelines create, may be credited to the joint account of the U.S. Sentencing Commission and the courts of appeals.

\section{Guideline Validity: The Neglected Appellate Issue}

The Commission told Congress in February 1992 that more than 92,000 defendants had been sentenced under the guidelines in the three years since Mistrett $^{237}$ was decided. ${ }^{238}$ The vast majority of cases, approximately eighty-eight percent, were resolved by guilty plea, where the parties had opportunities not present in trial cases to stipulate facts, agree on a sentencing range, and waive appeal. ${ }^{239}$ Nonetheless, about 5400 sentences are being appealed annually. ${ }^{240}$ Since sentences were rarely reviewed before the guidelines, this number represents a significant addition to appellate caseloads. More

235. See Jerry D. Denzlinger \& David E. Miller, The Federal Probation Officer: Life Before and After Guideline Sentencing, FED. PROBATION, Dec. 1991, at 49; Garoppolo, supra note 212; Probation Officers and the Guidelines, supra note 208, at 61-120 (collection of essays examining the role of probation officer in guideline sentencing).

236. 28 U.S.C. 8991 (b)(1)(B) (1988).

237. Mistretta v. United States, 488 U.S. 361 (1989).

238. Testimony of William W. Wilkins, Jr., Chairman, U.S. Sentencing Commission, before the House Subcommittee on Appropriations 2 (Feb. 25, 1992) (transcript on file with author).

239. See 1990 ANNUAL REPORT, supra note 15, tbl. C-7; Haines, supra note 234.

240. The Federal Judicial Center reported that approximately 5300 sentences were appealed in 1991 , Federal Judicial Center, Type and Number of Criminal Appeals Terminated, and Each Type as a Percentage of All Terminations (Apr. 1992) (data compiled from Federal Judicial Center's Integrated Database, transcript on file with author), and 5400 were appealed in 1990 . Federal Judicial Center, Type and Number of Criminal Appeals Terminated, and Each Type as a Percentage of All Terminations (Apr. 1991) (data compiled from Federal Judicial Center's Integrated Database, transcript on file with author). 
importantly, like never before, guidelines are compelling appellate judges to wrestle with the difficult task of sentencing. ${ }^{241}$

\section{A. The Gap Between Circuit Court and District Court Perspectives}

The outcry against the guidelines is less audible in the courts of appeals than at the trial level. Some appellate judges have forgotten what sentencing is like in district courts; some may not realize how much change guidelines have produced; others have never had sentencing experience. Still other judges with prior criminal trial experience appreciate the intensity of the reaction below, but view their appellate responsibilities as posing a different set of challenges.

Appeals court judges are reviewers, opinion writers, and rulemakers. They no longer look defendants in the eye, study presentence reports, or struggle with assessing whether an offender is beginning or ending a criminal career, appears to be dangerous or harmless, is a minnow in a sea of big fish, or has gone astray under unusually stressful circumstances and will not offend again. Appellate judges no longer see large numbers of worried or stunned faces, or multiple defendant cases covering the full range of criminal responsibility. The appeals court is remote from the universe of cases that make equality and proportionality in punishment, across different defendants and crimes, issues of transcendent importance.

Some trial judges view their appellate colleagues as thinking that guidelines are "written in stone" and that "an act of departure is something which has to be curbed." ${ }^{242}$ Some appellate judges, on the other hand, think their district court colleagues are too emotional about the guidelines and need an objective reviewer to give the new law of sentencing the bite of authority. They believe the current turmoil will settle down once appellate review places sensible limits on trial court departures. ${ }^{243}$

Such thinking is illusory. The courts of appeals have not fully recognized the remarkable degree to which the new rules deviate from the traditional system of individualized justice and its ideals. ${ }^{244}$ Those who do not actually sentence may not comprehend the complexity of the prescribed computations and the bizarre results they can produce. Moreover, the appeals court is insufficiently exposed to the range of offender differences that the Commission downplayed when it formulated a point scoring system, involving 258 sentenc-

241. Appellate judges should be careful not to assume that the sentencing appeals they hear are representative of the typical sentencing case. Sentencing appeals constitute little more than $10 \%$ of all criminal cases, and the great majority of cases sentenced after plea bargaining are not appealed. See supra note 240.

242. Public Hearing, supra note 10, at 290 (testimony of Judge Vincent L. Broderick).

243. Kleinfeld, supra note 10, at 16; Selya \& Kipp, supra note 58, at 49.

244. Public Hearing, supra note 10, at 289-90 (testimony of Judge Broderick); Cabranes, supra note 10 , at 2 . 
ing boxes, and narrowed the routes to individualization and proportionality. This unfamiliarity with the guidelines, particularly the extent to which they deviate from pre-guideline principles and practices, has led the courts of appeals to enforce the guidelines in ways that district court judges find increasingly intolerable. As a result, the gap between appellate decisions and district judges' experienced sense of justice is widening.

Looking more closely, how are the courts of appeals approaching their new sentence review function? Preliminary indications from an ongoing study of appellate review of departures suggest that courts of appeals reverse or remand a significant percentage of unguided departure sentences. This is especially true when the departure is based on offender characteristics. ${ }^{245}$ They have, for example, rejected departures by ruling that the Commission had adequately considered the particular aggravating or mitigating circumstance, such as the pregnancy of a defendant, ${ }^{246}$ even though the Guidelines Manual never mentioned the characteristic at issue. ${ }^{247}$ They have erroneously given policy statements the force of guidelines, even though the Commission and the Department of Justice construed the SRA as meaning that the opposite is true. 248

A number of circuits have reviewed comparatively few appeals from downward departure sentences in the past two years, despite Commission statistics showing that departures occur frequently. ${ }^{249}$ Some observers believe that the perceived hostility of a circuit court toward downward departures is responsible, not for fewer departures in the district courts, but for fewer appeals

245. For example, in the period from January 1990 through January 1992, the Second Circuit Court of Appeals reversed or remanded nearly two-thirds of appealed departure cases. During the same time period, by way of contrast, the Eighth Circuit Court of Appeals affirmed nearly two-thirds of appealed departure cases. For further elaboration of appellate treatment of departure cases, see Daniel J. Freed et al., Variations Among Courts of Appeals in Reviewing Departures Under the Federal Sentencing Guidelines (study-inprogress, on file with author).

Appellate courts have reversed or remanded numerous cases in which the district court departed based on offender characteristics. See, e.g., United States v. Sklar, 920 F.2d 107 (1st Cir. 1990) (defendant's rehabilitation improper basis for departure); United States v. Studley, 907 F.2d 254 (1st Cir. 1990) (district court's finding that defendant posed little or no risk to community improper basis for departure); United States v. Neil, 903 F.2d 564 (8th Cir. 1990) (defendant's military record not sufficiently meaningful to warrant departure).

246. See United States v. Pozzy, 902 F.2d 133 (1st Cir.), cert. denied, 111 S. Ct. 353 (1990). See generally 2 FED. SENTENCING REP. 161-98 (1989-1990) (issue discussing offender characteristics); 3 FED. SENTENCING REP. 8-34 (1990) (same).

247. The Guidelines Manual never mentions pregnancy. See U.S.S.G., supra note 1. "In determining whether a circumstance was adequately taken into consideration," the SRA requires the court to "consider only the sentencing guidelines, policy statements, and official commentary of the Sentencing Commission." 18 U.S.C. $\$ 3553(\mathrm{~b})$ (1988).

248. See infra Part V.B.1.

249. The Commission, in its annual reports and impact reports, keeps track of the frequency of departures by sampling 25\% of all sentencing cases during a certain time period. See 1990 ANNUAL REPORT, supra note 15, tbl. C-5; 1989 ANNUAL REPORT, supra note 50, tbl. C-5; U.S.S.C. IMPACT REPORT, supra note 2, at 205-41. By extrapolating the Commission's sample to annual totals and by studying appealed departures, an ongoing study by Manuel Abascal, Bruce Smith, and me estimates that upward departures are about 15 times more likely to be appealed than downward departures. See Freed et al., supra note 245. 
of those departures to the circuit courts. ${ }^{250}$ Through negotiated settlements, appeal waivers, or informal acquiescence, many participants in the trial process seem to be deciding for themselves that departures are necessary, and that the guidelines and the appeals courts are too strict.

To the extent that these informal decisions deprive appellate judges of a meaningful overview of the sentencing process in action, they increase the likelihood of uncorrectable disparity between dispositions settled by negotiation and cases reviewed on appeal; and between departures by flexible district judges who relax the rigor of the guidelines and refusals to depart by others who prefer to enforce or acquiesce in guideline prescriptions.

\section{B. The Gap Between Statutory Principles and Circuit Court Case Law}

This section examines how courts of appeals have misinterpreted the SRA. Torn between enforcing the unpopular guidelines of an administrative agency that sentences no one and respect for the expertise and the firsthand experience of district judges who sentence everyone, appeals judges seem to have opted in favor of the agency. Unintentionally and perhaps unknowingly, strict appellate rulemaking has failed to balance the distant guidance of a bureaucracy against the detailed responsibility of the individual sentencer.

Appellate courts are obliged to review Commission compliance with the SRA, as well as individual sentences. These functions are intertwined but not the same. By reviewing a sentence solely in relation to an applicable guideline, a court of appeals treats the guideline as though it were a freestanding act of Congress. But Congress did not enact the guidelines, and the President did not sign them. They are limited rules that become binding only through designated procedures, and they remain subordinate to the overriding statute. Reviewing agency actions is hardly a new task for appellate courts; they are accustomed to dealing with administrative agencies and to ensuring that the agencies comply with the governing statutes. There is no good reason for failing to ensure that Commission guidelines comply with the standards of the SRA.

By departing from an applicable guideline range, a district court expresses the view that the Commission's guidance does not adequately address the facts of the case. Whenever a court of appeals reviews the challenged sentence, it has a duty to consider four questions:

(1) whether the particular guideline or policy statement at issue was authorized by the SRA and complies with the statutory directive

250. Francesca D. Bowman, The Greening of Probation Officers in Their New Role, 4 FED. SENTENCING REP. 99, 100 (1991) ("IInn calendar year 1989 there were 36 court-initiated downward departures (of a total of 168 defendants sentenced under the guidelines); only three were taken up on appeal."). 
to be "consistent with all pertinent provisions of this title [28] and title 18 "; 251

(2) whether the provision in question is a presumptively binding guideline or an advisory policy statement;

(3) whether the aggravating or mitigating circumstances that led a district judge to depart from the guideline was "of a kind, or to $a$ degree, not adequately taken into consideration by the Sentencing Commission"; 252 and

(4) whether the guidelines, and their judicial interpretations, have produced a sentence that implements the statutory objective to "avoid unwarranted sentence disparities."253

These four questions are central to a responsible judicial interpretation of guideline validity. They underlie, and sometimes undermine, important actions taken by way of guidelines, policy statements, or judicial decisions.

The first question-whether the guideline or policy statement is authorized by and consistent with the statute--has already been analyzed in our discussion of policy statement $5 \mathrm{~K} 1.1$, dealing with substantial assistance. ${ }^{254}$ Courts of appeals have failed heretofore to notice two errors made by the Commission: (1) that insofar as 5K1.1 purports to implement 28 U.S.C. $\S 994(n)$, it goes beyond the statute by adding the unauthorized prerequisite of a government motion before the district judge can exercise discretion to reduce a nonmandatory sentence; and (2) that section $5 \mathrm{~K} 1.1$ is denominated a policy statement, which is inconsistent with Congress' instruction that $\S$ 994(n) be implemented by way of a guideline. The Commission should amend $5 \mathrm{~K} 1.1$ to correct these mistakes. Regardless, district judges and appellate courts should not hesitate to implement 28 U.S.C. $\S 994(n)$ by invalidating $5 \mathrm{~K} 1.1$ 's requirement that a government motion precede judicial consideration of sentence reductions in cases not involving mandatory penalties.

The subsections that follow deal with the three remaining issues.

\section{Not Distinguishing Policy Statements from Guidelines}

A major deficiency in trial court and appellate interpretations of the Guidelines Manual lies in the failure to appreciate the distinction between a policy statement and a guideline. The Supreme Court's recent decision in Williams v. United States refers to the guideline/policy statement relationship, but never articulates the differences and similarities between them. ${ }^{255}$

251. 28 U.S.C. \& 994(a) (1988).

252. 18 U.S.C. $\$ 3553$ (b) (1988) (emphasis added).

253. Id. $\$ 3553(\mathrm{a})(6)(1988) ; 28$ U.S.C. $\S 991(\mathrm{~b})(1)(\mathrm{B})(1988) ; 28$ U.S.C. $\S 994(\mathrm{f})(1988)$.

254. See supra Part III.C.2.c.

255. In March 1992, the Supreme Court referred to the policy statement/guideline relationship in Williams v. United States, 60 U.S.L.W. 4206 (U.S. Mar. 9, 1992). Justice O'Connor's majority opinion called the relevant policy statement "an authoritative guide to the meaning of the applicable guideline." Id. at 4209 . In sentencing Williams, the district court had departed upward based in part on his prior arrest 
"Guidelines" attain presumptive authority (subject to judicial review for consistency with the SRA) by being submitted to Congress, after a prescribed administrative hearing process, and surviving the six-month congressional report-and-wait period.

"Policy statements," 256 on the other hand, need follow no procedural due process or time schedule. They are not subject to legislative review. The SRA provides no route by which a policy statement may receive congressional endorsement, by silence or otherwise. The Department of Justice instructed U.S. Attorneys in its 1987 Prosecutors Handbook on Sentencing Guidelines that "policy statements . . . only provide general advisory statements which are not binding," and "[a] court is not required to abide by a policy statement suggesting a departure from the guidelines even though a factor is present in the case which is addressed by such a policy statement and insufficiently addressed by the guidelines themselves."257

Similarly, the Commission states in chapter 7 of the Guidelines Manual that "policy statements are not subject to the May 1 deadline for submission to Congress ... . [and] provide better opportunities for evaluation by the courts and the Commission." 258

Courts have repeatedly overlooked the policy statement label and its nonbinding status. Instead, they give policy statements the same effect as guidelines. The Commission cannot be faulted for these judicial errors. Rather, courts and the attorneys who argue before them are to blame. Courts have misread the Guidelines Manual and not read the SRA, while attorneys have failed to challenge the courts' misconceptions.

For example, a number of courts have failed to note that a section they called a "guideline" was in fact a clearly marked "policy statement." 259 Some have noted the words but ignored the distinction. ${ }^{260}$ Others note the distinc-

record, despite a policy statement making that factor invalid. U.S.S.G., supra note $1, \S 4$ A1.3. The court of appeals affirmed the sentence despite finding that the trial judge had erred in considering the arrest record. The Supreme Court remanded for a determination of "whether the sentence was imposed 'as a result of' the District Court's erroneous consideration of his prior arrests not resulting in prosecution." Id. at 4210 (quoting 18 U.S.C. $\& 3742(f)(1)(1988)$ ). The majority did not address the policy statement/guideline distinction discussed in this Article. In dissent, Justices White and Kennedy made more of the distinction, arguing that "[e]ven though policy statements are numbered and grouped in the Guidelines Manual by means identical to actual guidelines, their purpose is limited to interpreting and explaining how to apply the guidelines." Id. at 4212 (White, J., joined by Kennedy, J., ćissenting) (citation omitted).

256. 28 U.S.C. $\S \S 994(\mathrm{p}),(\mathrm{x})(1988)$.

257. PROSECUTORS HANDBOOK, supra note 75 , at 7 (emphasis omitted).

258. U.S.S.G., supra note 1 , ch. 7, pt. A, intro. 3(a); see also supra note 161 and accompanying text.

259. United States v. O'Brien, 950 F.2d 969 (5th Cir. 1991); United States v. Guajardo, 950 F.2d 203

(5th Cir. 1991); United States v. White, 945 F.2d 100 (5th Cir. 1991); United States v. Mondello, 927 F.2d 1463 (9th Cir. 1991); United States v. Prescott, 920 F.2d 139 (2d Cir. 1990); United States Daiagi, 892 F.2d 31 (4th Cir. 1989); Garoppolo, supra note 212, at 4-5.

260. United States v. Lopez, 938 F.2d 1293 (D.C. Cir. 1991); United States v. Shoupe, 929 F.2d 116 (3d Cir.), cert. denied, 112 S. Ct. 382 (1991). 
tion, but imply that it does not make any difference. ${ }^{261}$ Some say or imply that the difference is significant, but the outcome suggests that it was not. ${ }^{262}$ There are a few striking exceptions to this litany of errors, ${ }^{263}$ signifying that at least some trial judges ${ }^{264}$ and some appellate judges ${ }^{265}$ have carefully read the SRA and the Guidelines Manual.

There is, of course, nothing wrong with the Commission formulating policy statements and the courts following them. Judges clearly ought to respect sound advice offered by the Commission, regardless of whether it is binding. The real issue arises when a trial judge believes that a policy statement will produce an unjust result in a particular case: should nonbinding advice, for which the Commission offers inadequate justification and which contradicts prior justice system practice, be imposed on district courts simply because the Commission printed it in the Guidelines Manual?

It is rare for appellate courts to misread repeatedly the same statute and its administrative interpretations, yet they have done so on this issue. Because stare decisis serves no useful purpose when injustice and disparity follow in the courts below, it would be appropriate to reconsider earlier rulings.

\section{Not Testing the "Adequacy" of Guideline Consideration}

The word "adequately" in 18 U.S.C. § 3553(b) deserves special emphasis because the statute did not make mere Commission "consideration" the test of guideline legitimacy and enforceability. Congress nowhere stated or implied that the Commission's mention of a factor in a sentencing guideline, policy

261. United States v. Smith, 953 F.2d 1060 (7th Cir. 1992); United States v. Agu, 949 F.2d 63 (2d Cir. 1991); United States v. Thomas, 930 F.2d 526 (7th Cir.), cert. denied, 112 S. Ct. 171 (1991); United States v. Chotas, 913 F.2d 897 (11th Cir. 1990), cert. denied, 111 S. Ct. 1421 (1991); United States v. Gutierrez, 908 F.2d 349 (8th Cir. 1990); United States v. Franz, 886 F.2d 973 (7th Cir. 1989). banc).

262. United States v. Kelley, No. 90-1027, 1992 U.S. App. LEXIS 1445 (8th Cir. Feb. 5, 1992) (en

263. United States v. Lee, No. 91-6079, 1992 WL 27639 (10th Cir. Feb 19, 1992) (holding that policy statements in chapter 7 on supervised release are advisory rather than mandatory but must be considered by trial court); United States v. White, 869 F.2d 822 (5th Cir.), cert. denied, 490 U.S. 1112 (1989); see also United States v. Stinson, No. 90-3711, 1992 WL 56040 (11th Cir. Mar. 20, 1992) (holding official commentary not binding until Congress amends language of guidelines).

264. See, e.g., United States v. Pokuaa, 782 F. Supp. 747 (1992) (citing 18 U.S.C. § 3553(b) (1988), as authority for departure because Commission did not adequately consider loss of parental rights due to incarceration); United States v. Gerard, 782 F. Supp. 913 (1992) ('[I]t was not Congress' aim to straitjacket a sentencing court, compelling it to impose sentences like a robot inside a Guidelines glass bubble, and preventing it from exercising its discretion, flexibility, or independent judgment." (citing United States v. Lara, 905 F.2d 599, 604 (2d Cir. 1990))); United States v. Rodriguez, 724 F. Supp. 1118 (S.D.N.Y. 1989) (Leval, J.) (asserting Guidelines Manual permits departure from guidelines in an "atypical" case); United States v. Birchfield, 709 F. Supp. 1064, 1070 (M.D. Ala. 1989) (Thompson, J.) ("[T]he court believes that it is acting within the spirit and fulfilling the purpose of the guidelines in this case.").

265. See Lee, 1992 WL 27639 (Logan, J.); Kelley, 1992 U.S. App. LEXIS 1445 (Heaney, J., dissenting); Chotas, 913 F.2d 897 (Clark, J., concurring in part, dissenting in part); Gutierrez, 908 F.2d 349, 353 (Heaney, J., dissenting). 
statement, or official commentary would be sufficient to bind a district court ${ }^{266}$ It did not, as the Commission casually asserted in the original Guidelines Manual, authorize the Commission to decide for itself that it had adequately considered a topic. ${ }^{267}$ The question of adequacy was specifically delegated to courts by $\S 3553(\mathrm{~b})$.

The Commission could certainly say, as it did in section $5 \mathrm{~K} 2.0$ of the Guidelines Manual, that it had not adequately considered certain topics. But whether the converse was true, that it had adequately considered a factor, would depend in each case on a court's comparison of the facts with the explanation provided in the Guidelines Manual. If the Commission gave specific consideration in a guideline to an aggravating circumstance-like possession of a toy gun $^{268}$-and decided, for example, that the harmlessness of the toy outweighed the fear that such replicas can instill in victims; if it showed that it understood the emotional shock and situational variables involved; and that it fully weighed the advantages and disadvantages of adding or barring extra punishment for displaying an unworkable item, then a court, whether or not it agreed, might have to concede that the Commission's judgment was predicated on adequate (not "perfect") consideration.

Congress no doubt delegated the evaluation of "adequacy" to the sentencing court because it considered the judge to be in the best position to evaluate whether the Commission had sufficiently addressed the aggravating or mitigating circumstance "to the degree"269 present in the case. In United States $v$. Diaz-Villafane, ${ }^{270}$ the First Circuit misread the statute taking the view that "adequate consideration" was a question of law for the courts of appeals' de novo review. The appeals court went on to observe that:

District courts are in the front lines, sentencing flesh and blood defendants. The dynamics of the situation may be difficult to gauge from the antiseptic nature of a sterile paper record. Therefore, appellate review must occur with full awareness of, and respect for, the trier's

266. These are the three sources listed in 18 U.S.C. $\$ 3553(b)$ to which courts are confined when evaluating the adequacy of consideration of an issue by the Commission.

267. "Thus, in principle, the Commission, by specifying that it had adequately considered a particular factor, could prevent a court from using it as grounds for departure. In this initial set of guidelines, however, the Commission does not so limit the Court's departure powers." U.S. SENTENCING COMM'N, FEDERAL SENTENCING GUDELINES MANUAL ch.1, pt. A, intro 4(b) (1987) [hereinafter 1987 U.S.S.G.], reprinted in U.S.S.G., supra note 1, app. C, at 132. In 1990, the Commission deleted the quoted language by amendment 307 , accompanied with the puzzling explanation that "in the discussion of departures in subpart 4(b), language concerning what the Commission, in principle, might have done is deleted as unnecessary, but no substantive change is made." U.S.S.G, supra note 1, app. C., at 138.

268. United States v. Faulkner, 934 F.2d 190, 196 (9th Cir. 1991) ("As the use of a toy gun during a crime was clearly a circumstance considered by the Commission in formulating the Guidelines, it may not serve as a basis for departure from the Guideline range.").

269. The language "to a degree" was added to 18 U.S.C. $\$ 3553$ (b) by the Sentencing Act of 1987 , thereby intensifying the sentencing court's duty to review the adequacy of Commission consideration. Pub. L. No. 100-182, \& 3(1)-(2), 101 Stat. 1266, 1266.

270. United States v. Diaz-Villafane, 874 F.2d 43 (1st Cir.), cert. denied, 493 U.S. 862 (1989). 
superior "feel" for the case. We will not lightly disturb decisions to depart, or not, or related decisions implicating degrees of departure. 271

The appeals court acknowledged in this statement the importance of case facts when evaluating the appropriateness of a departure. But it overlooked the statute's instruction that those facts must be directly linked to the issue of the "adequacy" of the Commission's consideration: $\S$ 3553(b) tells the court to determine whether the factual circumstances in the case before it are "of a kind, or to a degree, not adequately taken into consideration by the Sentencing Commission." This is the essence of a mixed question of fact and law. ${ }^{272}$

"Adequately considered" provides the SRA's pivotal test for guarding against ill-considered guidelines and against needless rigidity in applying an otherwise sensible guideline to cases in which the kind or degree of circumstances warrant departure. The problem for courts trying to apply the test, however, is that the Commission, both in its original guidelines, and in 435 amendments from 1987 through 1991, has failed to articulate sufficiently the reasons for the various sentences mandated. ${ }^{273}$

Some might argue that this construction of "adequate consideration" imposes too great a burden on the Commission and the courts. For a court making the inquiry in a fact-specific context, review of "adequate consideration" is not difficult, especially when the Commission's published "consideration" is so thin. For the Commission, we also know that the burden of providing explanations for its guidelines is not so great; it has successfully done so before. In its Introduction to the 1987 Guidelines Manual, the Commission set forth a wide-ranging and fascinating account of its views on several major

271. Id. at $49-50$.

272. On each occasion, a court should ask: how carefully did the Commission consider the kind and degree of facts present in this case? The First Circuit's error in labeling such an inquiry a question of law is illustrated by the way it applied that test to the Diaz-Villafane facts. It reviewed five categories of facts to see if they supported the district court's upward departure: in two categories, dealing with "pending charges" and the "purity of heroin," it correctly found that the Commission had explicitly considered the issue and had guided courts to an upward departure. (No question was raised about the adequacy of Commission consideration.) But in the remaining fact categories, the First Circuit forgot to examine what the Commission had considered. It simply mentioned three sets of facts and silently assumed that the Commission had not considered them. Its ruling offers no useful test or precedent for a case in which the trial court departs and the issue on appeal is whether the Commission considered similar facts in writing its guidelines. The Diaz-Villafane case is discussed, and the de novo test criticized, in United States v. Nelson, 918 F.2d 1268 (6th Cir. 1990) (Ryan, J. concurring); see also Miller \& Freed, supra note 101, at 237.

273. See Miller, supra note 28 , at 24 . 
sentencing topics, setting a high standard for informing the courts and the public about administrative policymaking for federal sentencing. ${ }^{274}$

Senate Report 98-225 also sets a high and clearly attainable standard for reasoned explanations of sentencing principles in a legislative context. ${ }^{275}$ Through recourse to literature, case law, and illustrations, it provides a rich portrait of the process of defining principles and procedures for sentencing. It shows that Congress devoted much care to studying sentencing before enacting the statute, and it suggests the kind and quality of "reasons" Congress had in mind when it instructed the Commission to submit its guidelines and each amendment or modification "accompanied by a statement of reasons therefor., 276

If the Senate Judiciary Committee, with a host of legislative topics on its agenda, could provide a volume of well-considered reasons to explain its guidance to the Commission, surely the Commission, charged with the duty to "establish sentencing policies and practices for the federal criminal justice system that ... reflect, to the extent practicable, advancement in knowledge of human behavior as it relates to the criminal justice process, ${ }^{277}$ could do at least as well in its guidance to the federal courts.

The process by which the Commission could articulate the evolution of policymaking is not hard to envision. The Commission produced the 200-page Guidelines Manual in its first year. By mid-1988, district courts began applying the guidelines in large numbers of cases and submitting detailed case reports to the Commission pursuant to 28 U.S.C. $\S 994(w)$. By 1989, the courts of appeals were issuing opinions in large numbers of sentence review cases. Judges, lawyers, and scholars expected that the Commission would begin revising and annotating the Guidelines Manual, offering leading case citations, judicial opinion quotations, and its own analysis and commentary on the evolving application of law to sentencing issues and recurring factual situations. This sort of commentary would provide on a policy level what case law provides for individual cases: an explanation of rules, their origins, their reasoning, their exceptions, their modifications over time, and their rationality in a complex system.

274. U.S.S.G., supra note $1, \mathrm{ch} .1, \mathrm{pt}$. A. It is therefore puzzling that it never did so again, especially with regard to guideline provisions that encountered substantial resistance. Thomas W. Hillier II, The Commission's Departure from an Evolutionary Amendment Process, 4 FED. SENTENCDNG REP. 45 (1991); see also Leonard Orland, Corporate Punishment by the U.S. Sentencing Commission, 4 FED. SENTENCING REP. 50, 52 (1991) (in promulgating organizational sentencing guidelines, Commission "acted without an articulated theoretical or empirical justification").

275. S. REP. No. 225 , supra note 9 .

276. 28 U.S.C. $\$ 994($ p) (1988). The reasons required by this section should be sufficient to satisfy the "adequacy of consideration" test in 18 U.S.C. \$ 3553(b) (1988). See Leonard Orland, The Commission's Supplemental Report on Corporate Punishment: Where is the Statement of Reasons?, 4 FED. SENTENCING REP. 158 (1991).

277. 28 U.S.C. $\$ 991(f)(1)(C)(1988)$. 
A few courts of appeals have carefully considered the need to explain sentencing policies. ${ }^{278}$ Some have acknowledged the flaw in a guideline, complimented the district judge for pointing it out, but deemed themselves powerless to take corrective action. ${ }^{279}$ Most courts of appeals, however, continue to let the Commission off the hook with regard to demonstrating the adequacy of consideration underlying key guidelines and policy statements.

If the guidelines were working well in the district courts, the Commission would have earned credibility with the judiciary by now. But at present, the opposite is true: avoidance of unreasonable guidance abounds in the interests of justice, but only at the expense of openness and disparity. District and appellate courts should begin imposing a high burden of explanation on the Commission to stimulate "adequate" consideration for each troublesome guideline and policy statement.

\section{Not Implementing the Instruction to "Reduce Unwarranted Disparity"}

In at least three places in the SRA, Congress included instructions to reduce unwarranted disparity: it admonished judges in 18 U.S.C. § 3553(a)(6) to "avoid unwarranted disparities"; and it told the Sentencing Commission in 28 U.S.C. $\S \S 991$ (b)(1)(B) and 994(f) to promulgate guidelines and policy statements that accentuate "certainty and faimess" in sentencing, while reducing "unwarranted sentence disparities."

Despite these provisions, a number of appellate courts have (1) reversed district courts when they equalize sentences among codefendants, or (2) declined to review sentences where district courts refused to depart in situations similar to those in which an appeals court had already sustained a departure. The courts of appeals should reconsider both lines of cases. They have also (3) not taken adequate account of the current "hidden disparities" that prevail in the district courts, and (4) failed to explore sufficiently the consequences of decisions that require sentencing judges to consider illegal evidence.

\section{a. Equalization}

District judges have on occasion departed from the guidelines when they felt that codefendants merited similar sentences, even though guideline calculations put them in different ranges. Appellate courts have reversed such decisions, reasoning that the guidelines are designed for nationwide application, and

278. See, e.g., United States v. Takai, 930 F.2d 1427 (9th Cir. 1991) (Noonan, J.).

279. See United States v. Deane, 914 F.2d 11 (Ist Cir. 1990); United States v. Studley, 907 F.2d 254 (Ist Cir. 1990). 
that adherence to uniform standards takes precedence over equalization among individuals convicted in the same courthouse. ${ }^{280}$

Sentencing Commission statistics show wide variations in sentence lengths and departure practices among different districts. ${ }^{281}$ So long as the guidelines demonstrate an inability to prevent gross discrepancies like these, it is counterproductive for any court to reject sentencing equalization decisions that promote consistency in the same jurisdiction with the rationale that to do so might disturb some theoretical (and unrealized) nationwide ideal.

\section{b. Failure To Depart}

Appellate courts should also reconsider decisions implying that sentencing principles established in cases where district judges depart are not binding in similar situations where judges fail to depart. At present, appellate courts review departure sentences and make rulings that distinguish between departures that are appropriate and those that are not. It is therefore anomalous that when district judges fail to depart, appeals courts say they lack jurisdiction to review. Such decisions make little sense when they effectively affirm disparity for defendants denied departure on grounds that a previous appellate court already ruled appropriate. ${ }^{282}$

If the SRA offered no possibility for exercising jurisdiction over failures to depart, it would be incumbent on the judiciary to ask Congress to rectify the omission. But to decline to review a failure to depart in a situation where, by so declining, the appellate court is effectively refusing to avoid "unwarranted disparities" contrary to the SRA must be a misinterpretation of 18 U.S.C.

280. United States v. Gessa, 941 F.2d 265, 270 (6th Cir. 1991); United States v. Wogan, 938 F.2d 1446, 1447-48 (1st Cir.), cert. denied, 112 S. Ct. 441 (1991); United States v. Carr, 932 F.2d 67, 73 (1st Cir.), cert. denied, 112 S. Ct. 112 (1991); United States v. Joyner, 924 F.2d 454, 459-61 (2d Cir. 1991); United States v. Rey, 920 F.2d 562, 567-68 (9th Cir. 1990), cert. denied, 111 S. Ct. 1084 (1991); United States v. Enriquez-Munoz, 906 F.2d 1356, 1359-60 (9th Cir. 1990). But see United States v. Boshell, 952 F.2d 1101, 1106-09 (9th Cir. 1991) (upholding equalization of defendant whose guideline sentence would have been longer than that of a more culpable codefendant).

281. Compare, for example, robbery sentence lengths in the Northern District of California ( 83 months) with those in the Northern District of Georgia (164 months), 1990 ANNUAL REPORT, supra note 15, app. $B$; and departures in the Eastem District of Pennsylvania (40.z) with those in the Southern District of Illinois (2.9\%), id. tbl. C-5.

282. See United States v. Porter, 924 F.2d 395, 399 (1st Cir. 1991); United States v. Davis, 919 F.2d 1181, 1187 (6th Cir. 1990); United States v. Dean, 908 F.2d 215 (7th Cir. 1990), cert. denied, 111 S. Ct. 2801 (1991); United States v. Tillem, 906 F.2d 814, 828 (21 Cir. 1990).

However, some circuits have carved out an exception when the district court judge did not realize that the guidelines allowed him to depart. See United States v. Cook, 938 F.2d 149 (9th Cir. 1991); United States v. Lowden, 905 F.2d 1448 (10th Cir.), cert. denied, 111 S. Ct. 206 (1990); United States v. Rosen, 896 F.2d 789 (3d Cir. 1990); see also United States v. Deigert, 916 F.2d 916 (4th Cir. 1990) (remanding where unclear whether judge believed he lacked authority to depart).

Some judges and commentators have strongly criticized the appellate courts' failure to review district court departure decisions. See United States v. Denardi, 892 F.2d 269, 272 (3d Cir. 1989) (Becker, J., dissenting); Marc Miller \& Daniel J. Freed, The Emerging Proportionality Law For Measuring Departures, 2 FED. SENTENCING REP. 225 (1990); David Yellen, Appellate Review of Refusals to Depart, 1 FED. SENTENCING REP. 264 (1988). 
§ 3742(a)(2)-which authorizes appeal "as a result of an incorrect application of the sentencing guidelines."

\section{c. Hidden Disparities}

Low visibility dispositions and appeal waivers that shield many of today's sentences from appellate scrutiny have at least two sources: rigid guidelines and overly strict appellate standards. Courts of appeals alone cannot change this environment, but they can take steps to bring the sentencing system more into the open. Their goal should be to encourage reluctant trial judges to exercise discretion visibly, to put the actual facts of cases on the record, and to cast light on hidden disparities as well as on justifiable departures. Appeals courts should exercise their power to compel Commission reconsideration of unreasonable guidelines that drive sentencers underground. They should assure district judges that departures are an essential and respectable part of the system Congress established, rather than evidence of noncompliance. Moving the system in this direction would enable the Commission to correct its guidelines on the basis of visible departure experience that exposes flaws in the underlying guidelines.

\section{d. Illegal Evidence}

A specific illustration of decisions that encourage hidden disparities lies in cases that sustain or require a sentencer's reliance on illegal evidence as a basis for sentencing. ${ }^{283}$ Prior to the guidelines, the Supreme Court balanced the likelihood of deterring Fourth Amendment violations against "the costs of withholding reliable information from the truth-seeking process." ${ }^{.284}$ In reviewing guideline sentences, however, appellate courts should not ignore the relevant conduct consequences discussed earlier: enhancing a sentence on the basis of unadjudicated conduct gives prosecutors an incentive to drop dubious charges and later enhance a sentence based on information underlying those charges. ${ }^{285}$

The Second Circuit's recent decision in United States v. Tejada ${ }^{286}$ suggests that the Court may not have realized the extent to which its decision will encourage investigative agencies to lessen their concerns about the legality and admissibility of evidence. In ruling that illegally obtained evidence was admissible to determine the defendant's guideline sentence, the court held that "[a]bsent a showing that officers obtained evidence expressly to enhance a sentence, a

283. United States v. Tejada, No. 91-1071, 1992 U.S. App. LEXIS 2921, at *18-20 (2d Cir. Feb 21, 1992).

284. Illinois v. Krull, 480 U.S. 340, 347 (1987); United States v. Tucker, 404 U.S. 443 (1972).

285. See supra Part III.C.2.d (discussing U.S.S.G., supra note $1, \S 1 B 1.3$ ).

286. 1992 U.S. App. LEXIS 2921. 
district judge may not refuse to consider relevant evidence at sentencing, even if that evidence has been seized in violation of the Fourth Amendment."287

Such a rule under the guidelines turns the goal of legality in police investigations upside down. Because of the expansive relevant conduct approach provided by the guidelines, the prosecutor in Tejada, who had to drop firearm possession charges at trial because the evidence was illegally obtained, was still able to use the defendant's illegal gun possession to enhance the sentence for related drug charges. Together, the Tejada decision and the guidelines' relevant conduct approach significantly reduce the disincentives for police and prosecutors to obtain illegal evidence. Except where there is proof that a specific desire to enhance sentencing motivated the illegal search, district courts following Tejada will be obliged to consider the relevance of the illegal evidence to an enhanced sentence. If fairness in sentencing is a goal of the SRA-and surely 28 U.S.C. $\S \S 991(b)(1)(B)$ and $994(f)$ state that it is ${ }^{288}$-why should a court of appeals turn guideline sentencing into a process that rewards police illegality by inflating the target's punishment? ${ }^{289}$

Decisions like Tejada also compound the problems of informal noncompliance with the guidelines. As noted earlier, the "sentencers" who participate in the district court process resist unjust rules in all sorts of ways. Thus, an appellate rule that encourages the use of illegal evidence will likely encounter resistance from many prosecutors, defense attorneys, and judges. As defense counsel become knowledgeable of the harsh new rule, they will strive to condition guilty pleas on the AUSA's agreement not to offer illegal evidence at sentencing. Some prosecutors will do so as a matter of personal policy. Some judges will reject plea bargains that are predicated on illegal evidence. However, other prosecutors and judges will use illegal evidence to enhance sentences. Because neither the Commission nor an appeals court can stop lower court participants from respecting Fourth Amendment values, needless, unwarranted, hidden disparity contrary to the SRA will result.

\section{RETHINKING THE GUIDELINES}

There are at least two approaches to reducing unwarranted sentencing disparity: a legislature or outside agency can try to force it out of the system with severe rules; or courts, in cooperation with an agency, can probe the causes of disparity and evolve agreed-upon principles and norms to help sentencers achieve greater consistency. The latter is a peaceful route; the former spells trouble.

287. Id. at *19-20 (emphasis added).

288. 28 U.S.C. $\$ 994(\mathrm{~b})(1)$ (B) (1988) (listing "fairness" as one of Commission's purposes); id. \$ 994(f)

(1988) (instructing Commission to pay particular attention to "fairness in sentencing").

289. See Pilchen, supra note 85 , at 115. 
The U.S. Sentencing Commission chose the former. The district courts, substantially divided, have tended to acquiesce passively, criticize the new regime, or avoid unpalatable sentences by endorsing negotiated settlements. The courts of appeals, less divided, have tended to do just the opposite. They have enforced the Commission's rigid approach and have been unconcerned with system impact. This concluding part briefly examines what went wrong and suggests changes.

\section{A. What Went Wrong?}

Since the passage of the SRA, the Commission and the courts have played major roles in creating a sentencing system that works poorly. The Commission has three continuing problems-unbalanced membership, inadequate research, and mixed messages about departures-all of which hamper its ability to create workable guidelines. The judiciary, largely through misinterpretation of the SRA and the Guidelines Manual, has compounded the Commission's failures.

\section{The Sentencing Commission}

\section{a. Membership}

In retrospect, the trouble began with the appointment of the Commission's initial seven members. These were men and women of quality and high regard in their respective professions, but not leaders in the lengthy effort for sentencing reform. The Commission consisted of five men and two women: three judges (two court of appeals, one district court), a correctional official, and three professors-an economist, a sociologist, and a criminal law scholar. ${ }^{290}$ Several members had prior congressional staff experience, and one was an acknowledged expert in administrative law.

None of the members had extensive experience in sentencing offenders in a high-volume urban court. There was no U.S. Attorney or line prosecutor with recent trial experience in contemporary federal crime, no federal defender or private attorney skilled in criminal representation and sentencing advocacy, and no federal probation officer who had analyzed a wide range of offender characteristics or devised punishment options to match offenders' risks or rehabilitative potential.

No member had significant experience with the process of change, with efforts to reform the criminal justice system, or with the obstacles to modifying

290. The original Commissioners were: Stephen G. Breyer, Judge (now Chief Judge), 1st Cir.; Michael K. Block, Professor of Law, Policy \& Economics, University of Arizona; Helen G. Corrothers, U.S. Parole Commissioner; George E. MacKinnon, Senior Judge, D.C. Cir; Ilene H. Nagel, Professor, Indiana University School of Law; Paul H. Robinson, Professor, Rutgers School of Law; William W. Wilkins, Jr., Judge, D. S.C. (now Fourth Circuit). 
a multidiscretionary decisionmaking process with long traditions and specialized roles. ${ }^{291}$ In retrospect, the Commission acted as though it were unfamiliar with incremental approaches to change and with the futility of imposing radical rules on a complex system.

There was important precedent for the Commission's task, a five-year precedent that demonstrated the sort of sensitivity to issues of change from which a novice agency could benefit: the Minnesota Sentencing Guidelines Commission. ${ }^{292}$ As Dale Parent, its first staff director, recounts, the chair of Minnesota's Commission, Jan Smaby, devised an "open process of guideline development" to respect "the balance of divergent interests in criminal justice. Sources of opposition had to be identified and neutralized. Sources of support had to be located and nurtured."293 When discussions "revealed deep and intense divisions, she often deferred decisions, giving all parties time to seek additional information or accommodations." 294 The open process "enhanced the acceptability of the emerging guidelines."295

As the U.S. Sentencing Commission's initial guidelines came into general use and noncompliance became evident, it gained exposure to the dimensions of system resistance and to the desires of the federal judiciary and the organized bar to become participants in the process of change. ${ }^{296}$ When Congress finally directed the Commission in 1989 to examine the impact of mandatory minimum sentencing statutes, ${ }^{297}$ the Commission mounted a comprehensive study of how judges, prosecutors, and others were responding to a rigid system of severe prison penalties. In August 1991 the Commission reported that massive evasion and nullification of the congressionally imposed penalties had emerged. ${ }^{298}$ In a wide-ranging and thoughtful analysis, it recommended that Congress desist from mandating minimum sentences, a hopeful sign in the Commission's own learning process. ${ }^{299}$

Readers of the report cannot avoid observing the resemblance between the statutory mandates the Commission condemned and the guideline mandates its

291. See generally RAYMOND T. NMMMER, THE NATURE OF SYSTEM CHANGE (1978); SOCIAL HisTORY AND SOCIAL POLICY (David J. Rothman \& Stanton Wheeler eds., 1981); CHARLES E. LINDBLOM \& DAVID K. COHEN, USABLE KNOWLEDGE: SOCIAL SCIENCE AND SOCLAL PROBLEM SOLVING (1979); MALCOLM M. FeEley \& AUSTIN D. SARAT, THE POLICY DILEMMA: The CFISIS OF THEORY AND PRACTICE IN THE LEAA (1980).

292. It is also important to note the membership differences between the two commissions. Minnesota had a public defender, a state's attorney, the commissioner of corrections, and citizen members, in addition to experienced trial judges and others. See PARENT, supra note 7, at 31-32.

293. Id. at 45.

294. Id. at 47.

295. Id. at 48.

296. See The Sentencing Commission and Its Critics, supra note 122, at 205-52 (statements of Judges Becker, Broderick, and Wolf).

297. Crime Control Act of 1990, Pub. L. No. 101-647, § 1703, 104 Stat. 4789, 4845-46 (1990).

298. See MANDATORY MINIMUM PENALTIES REPORT, supra note 4.

299. Id. at iv, 33-34, 124. 
own Guidelines Manual contained. ${ }^{300}$ So far, however, the Commission seems not to have noticed. ${ }^{301}$

While it may not be too late for the Commission to reform itself from within, its unbalanced membership and lack of experience with what Raymond Nimmer called "the nature of system change"302 are impediments that may be difficult to overcome.

\section{b. Research}

In launching a study of federal sentencing, the Commission failed to devote sufficient attention to uncovering the sources of disparity among judges. PreSRA studies found differences in the sentences different judges gave in the same or similar cases, ${ }^{303}$ but devoted insufficient research to finding the roots of those differences. Judges confronted with disparity studies usually asserted that disparity was overstated. They felt that the differences lay more in the individuality of the cases than in the identity of the judges. ${ }^{304}$ Every case was unique-in the circumstances of the crime, the history and characteristics of the offender, and the variables in case processing. Until researchers could study different sentences in nearly identical, real-life cases, judges thought, they would not know whether the "disparity" was warranted or unwarranted. In drafting the SRA, Congress made it clear that "unwarranted disparities," not explainable differences, were the target.

With this issue of meaningful differences in mind, it is instructive to look at how the Commission actually studied it. In its June 1987 Supplementary Report, which followed the initial submission of proposed guidelines to Congress, the Commission said it had analyzed data drawn from 10,000 "augmented presentence reports" and the ensuing sentences in order to learn which distinctions were important. ${ }^{305}$ But probation officers write presentence reports, while judges impose sentences. Examining presentence reports told the Commission much about what was furnished in writing to judges, but little about how judges themselves processed sentencing information, considered individual offender differences, and determined which purpose or purposes dominated in different kinds of cases.

300. See Tonry, supra note 168 , at 131-32.

301. For a contrary view, i.e., that the mandatory penalty system is in fact a good idea that is working well, see Mueller, supra note 219.

302. NIMMER, supra note 291.

303. See sources cited supra note 9; infra Part I.A.; see also, e.g., Karlton Letter, supra note 10, at 186 ("TThe goal of uniformity in sentencing presupposes a uniformity of crime and criminals which simply does not exist.").

304. Cf. BLUMSTEIN ET AL., supra note 30, at 75 (noting "appearance of disparity" exists "when cases seem alike to an outside observer but differ materially in case attributes observed by the judge").

305. U.S. SENTENCING COMM'N, SUPPLEMENTARY REPORT ON THE INITIAL SENTENCING GUIDELINES AND POLICY STATEMENTS 9 (1987). 
The Commission's study failed to describe the extent to which the additional factfinding judges engaged in after receiving the presentence reports affected their sentences; what purposes judges connected to what sorts of crimes or offenders, leading to what sorts of sentences; what sanctioning options judges considered or would have considered had the resources existed; what prior cases and system norms judges found to be useful precedents; how judges dealt with an offender's substance abuse, employment record, dependents, or community ties; or what feedback was gleaned from comparing judges' nonprison sentences with prison sentences for similar offenders. From what the Commission disclosed in its Supplementary Report, it apparently spent little time systematically studying judges and the process of formulating sentences: talking with judges; observing them in action; interviewing prosecutors, probation officers, and defenders about judges; and discovering the wisdom accumulated over years on the bench.

The Commission wrote its guidelines in a partial vacuum, based primarily on prison sentence statistics and presentence reports, omitting consideration of the judgment and thinking processes of the judges who produced those sentences. Perhaps as a result, the Commission's guidelines also underestimated the interactions of judicial discretion with discretion exercised by other "sentencers," the critical role that purpose plays in formulating an appropriate sentence, and the pervasive importance of an offender's "history and characteristics" to individualized sentencing.

The Commission saw a system in which it wished to impose uniformity. To do this, it described a "heartland," but failed to recognize how often cases in real life warranted sentences outside that region. The Commission's research, in short, did not give it a sufficient appreciation of the district court environment for which guidelines were intended.

\section{c. Mixed Messages About Departures}

Another problem arose from the conflicting messages sent by the Commission to those interpreting and applying the guidelines. The guidelines were greeted in 1987 with press reports about how the Commission was taking discretion away from judges, but the Introduction to the Guidelines Manual conveyed a more modest message. It discussed the choices confronted in the policymaking process, and the sources, strengths, and weaknesses of the guidance adopted. The Introduction suggested considerable flexibility in the Commission's approach to guidance, but the rest of the volume hardly vindicated that approach.

After describing how it might have exercised its power to curtail departures, the Introduction said: "the Commission does not so limit the courts' departure 
powers." ${ }^{306}$ It expressly invited judges to depart in unusual cases. It described a "heartland" based on "typical cases embodying the conduct that each guideline describes," and said that where courts find "conduct [that] significantly differs from the norm," they should consider whether departure is warranted. Except for eight itemized factors, ${ }^{307}$ the Commission said that it "does not intend to limit the kinds of factors (whether or not mentioned anywhere else in the guidelines) that could constitute grounds for departure in an unusual case." ${ }^{308}$ It also mentioned that "single acts of aberrant behavior . . . still may justify probation at higher offense levels through departures. ${ }^{309}$

The Commission speculated that its guidance would probably prove acceptable "to those who seek more modest, incremental improvements in the status quo ... and who recognize that these initial guidelines are but the first step in an evolutionary process." ${ }^{\text {"310 }}$ It acknowledged the "difficulty of foreseeing and capturing a single set of guidelines that encompasses the vast range of human conduct potentially relevant to a sentencing decision." ${ }^{311}$ Noting that it was a permanent agency, it expected that the guidelines would develop "with progressive changes, over many years." ${ }^{312}$ By "monitoring when courts depart ... and by analyzing their stated reasons," it would be able over time "to create more accurate guidelines. ${ }^{\prime 313}$

The strict language of the guidelines and policy statements themselves, however, undercut this modest message. Readers of these mixed messages had a clear choice: they could assume that the Introduction authoritatively spelled out a policy of flexibility, under which departures were welcome, or they could interpret each guideline strictly as though it were written in stone.

The next two sections examine how these conflicting messages were received.

\section{District Courts}

District judges have reacted reflexively to the latter message. They have roundly criticized the guidelines, accepting the publicity about diminished discretion rather than carefully studying the statute and the Guidelines Manual to gain a comprehensive sense of how one might do justice under the new system. Relatively few judges seem to have read the Introduction; hardly any

306. 1987 U.S.S.G., supra note 267 , ch.1, pt. A, intro 4(b), reprinted in U.S.S.G., supra note 1, app. C, at 132 .

307. Id. (listing $\$ 5 \mathrm{H1.10}$ (race, sex, national origin, creed, and socioeconomic status), § $5 \mathrm{H1.4}$ (drug and alcohol dependence), and $\$ 5 \mathrm{~K} 2.12$ (personal financial difficulties or economic pressures) as invalid grounds for departure).

308. Id.

309. Id. at intro. 4(d), reprinted in U.S.S.G., supra note 1, app. C, at 134.

310. Id. at intro. 3, reprinted in U.S.S.G., supra note 1, app. C, at 130.

311. Id. at intro. 4(b), reprinted in U.S.S.G., supra note 1, app. C, at 132-33.

312. Id., reprinted in U.S.S.G., supra note 1, app. C, at 133.

313. Id. 
have referred to it when stating sentencing reasons. After Mistretta validated the Commission in 1989, ${ }^{314}$ judges lamented that their hands were tied, their power reduced.

Then and now, large numbers of judges have seemed unaware of the elasticity and latitude left open under the SRA and the Guidelines Manual. Few have realized the extent to which the statute empowers them to hold the Commission's guidelines accountable to specific instructions and virtually requires them to depart when the prescribed sentence seems inappropriate. Few have invoked or even mentioned the statutory rule in 18 U.S.C. $\$ 3553$ (a) that sentences must be "sufficient, but not greater than necessary" to comply with designated statutory purposes.

Nor have many district judges invoked the purposes-of-sentencing provisions of $\S 3553(\mathrm{a})(2)$ to shape sentences differently, depending on whether they have thought it necessary, for example, "to protect the public from further crimes of the defendant," or to impose "educational or vocational training, medical care, or other correctional treatment" as a more appropriate purpose.

Dismayed by chapter $5 \mathrm{H}$ policies that discourage reliance on offender characteristics, few judges have seemed aware of explicit authority elsewhere in the Guidelines Manual, as well as in the statute, for taking these traditional considerations into account. They have seemed oblivious to the individualizing factors - "the history and characteristics of the offender"- that 18 U.S.C. $\S 3553($ a) requires them to consider. Judges have also seemed oblivious to the prohibition against limiting a court's consideration of "information concerning the background, character and conduct of a defendant ${ }^{315}$ when determining a sentence within the guideline range, or departing from the range. Few have recognized the significance of the Commission's labeling of its chapter $5 \mathrm{H}$ "not ordinarily relevant" policies as policy statements instead of binding guidelines. Few have realized that even if a characteristic is not ordinarily relevant, the statement clearly invites a finding that it is relevant on some occasions.

The themes of Commission accountability, sentencer flexibility, and a statutory duty to depart offer abundant opportunities for district courts to take affirmative action to sentence justly and depart from flawed guidance. Congress has provided for an interactive system, involving judges and Commissioners, in which district courts can verify Commission compliance with the SRA and departures can provide feedback, leading ultimately to improvements as the guidelines evolve. The record of the first five years, however, suggests that sentencers, collectively, have fallen short of the pivotal role Congress has invited them to play. 


\section{Courts of Appeals}

Appellate courts have reacted similarly to publicity about the district courts' loss of sentencing discretion. Many appeals court judges have adopted a strict enforcement approach, holding district courts accountable to unquestioned guidelines, but not holding the Commission and its guidelines accountable to the SRA.

Appeals courts have also avoided reading the Introduction to the Guidelines Manual, choosing instead to enforce policy statements as though they were guidelines, and curtailing the statutory duty to depart as though it was a sin to venture outside the guideline range. Courts of appeals have acted more like super-sentencing commissions. They have assumed the role of protectors and elaborators of the guidelines, rather than the role of sentence reviewers, who, as 18 U.S.C. § 3742 suggests, defer to the knowledge and firsthand experience of the sentencing judge.

In short, appeals courts seem to have adopted an almost conclusive presumption of administrative expertise that the Commission in its first five years has not earned and that the statute does not contemplate.

\section{B. Where to Next?}

The judiciary, the Commission, and Congress should take a number of steps to redress deficiencies in the current guidelines system. Most do not require new legislation. They do, however, necessitate a change of attitude on the part of decisionmakers firmly set in their ways.

The surge of mandatory penalties enacted by Congress in recent years ${ }^{316}$ signifies a different political environment for sentencing reform compared to the mood that prevailed when the SRA became law. This altered context might lead some to consider the following proposals unrealistic. So be it; they are offered not as predictions of the future, but as lessons distilled from the past.

316. See MANDATORY MINMUM PENALTIES REPORT, supra note 4, app. A (listing statutory provisions requiring mandatory minimum terms of imprisonment); see also id. app. B (listing pending mandatory minimum legislation). 


\section{The Judiciary}

The judiciary is uniquely positioned to take the lead in reforming the current sentencing process. Since it appears that neither Congress nor the Commission is willing to correct deficiencies without prodding, the judiciary should act as the prod.

\section{a. Courts of Appeals}

Federal appellate courts should begin holding the Commission accountable as an agency of limited powers. The appeals courts should ensure that the guidelines conform to the detailed SRA provisions in titles 18 and 28 of the United States Code. They should accord greater deference to district court sentencing experience. As appellate panels become knowledgeable about noncompliance on the district court level, they should reconsider strict enforcement of guidelines that are encouraging manipulation and avoidance instead of respect for law.

An appeals court considering a sentencing case might, for example, request data on the disposition of similar cases in the court below, thereby exposing itself to the universe of sentences the criminal docket is producing, rather than taking account only of the fraction of cases it reviews directly. Perhaps, too, appellate judges should request occasional assignments to criminal cases in a district court to gain insight on how the guidelines are affecting sentencing judges. ${ }^{317}$ Such experience may hold special value for reassessing the Commission's relevant conduct rule, the policy statements governing substantial assistance and specific offender characteristics, and previous appellate rulings rejecting sentence equalization and the reviewability of failures to depart.

A primary focus when reviewing sentence departures should be on conformity of the relevant guideline to the SRA, and on the adequacy of the consideration the Commission gave to the degree of aggravation or mitigation produced by the circumstances in question. This sort of scrutiny might spur the Commission to begin spelling out its consideration of these factors in reasoned detail, much the way courts do in judicial opinions. Such review might inspire the Commission to reconsider major portions of its Guidelines Manual and to proceed more cautiously and with better reasons in the amendment process. ${ }^{318}$

Finally, a court of appeals, when examining a district court's reasons for departure, should avoid making the statement of reasons so burdensome as to discourage departures in cases where they would be appropriate. The appeals

317. Even for appeals court judges who once sat on the district court, it may be difficult to appreciate the complexity of trying to determine relevant conduct under the new system. See, e.g., Cabranes, supra note 10 , at 2 ("[N]o one can pretend to understand the work of federal judges today without some appreciation of the Guidelines system and what it has done to the courts . . ..").

318. Miller, supra note 28 (manuscript at 27-29). 
court should recognize the multiple functions served by a sentencing judge's remarks in the courtroom; crafting reasons for appellate scrutiny is only one function, and at the moment of sentencing, it is not the most important.

\section{b. District Courts}

Sentencers should think twice before continuing to follow the sequence of mechanical steps itemized by the Commission in Application Instructions guideline section 1B1.3. Judges should instead study the sequence defined by Congress in 18 U.S.C. $\$ 3553$ (a). The two chronologies are not the same, and the guidelines' deviation from the statute clouds its validity. Judges should carry out the elements of section 1B1.3 and the statute in the order that Congress prescribed: ${ }^{319}$ the facts of the case should be considered first-i.e., the "nature and circumstances of the offense and the history and characteristics of the offender"- and two key elements of sentencing omitted from the Commission's Instructions should be brought back into view-the purposes of sentencing and the policy favoring sentences "sufficient, but not greater than necessary."

Trial judges should question closely any Commission guideline or policy statement that offends their sense of justice. For example, when a Commission rule appears likely to produce an unjust sentence, the court might on occasion invite a Commission representative to attend the sentencing hearing and ask him to indicate where in the Guidelines Manual the circumstances at issue in the case were "adequately taken into consideration." ${ }^{.320}$ Or, the judge might request counsel for the defendant and the government to discuss in open court the factors that would have been considered in determining a pre-guidelines sentence and the extent to which the applicable guidelines, policy statements, and commentary demonstrate that the Commission took adequate account of those considerations.

If the court is satisfied, it should apply the guidelines as written. If not, the sentencing hearing should lay the foundation for a statement of reasons spelling out guideline deficiencies and justifying a departure under 18 U.S.C. \& 3553(b). The district judge might ask counsel to suggest a statement of reasons informing the reviewing court of the facts and purposes on which the sentence was based, an analysis of what the Commission considered in formulating the applicable guideline, and why those considerations were inadequate for the particular facts of the case.

Over time, analyses of this sort could move the guidelines in a direction that more thoughtfully accounts for the complexity of the sentencing process. 


\section{c. Judicial Conference of the United States}

The Judicial Conference is the governing policy body of the federal court system. It has become increasingly aware in recent years that the guidelines command little respect among judges and practitioners. As a consequence, the Conference has become admirably more assertive in recommending guideline changes to the Commission and in testifying in opposition to amendments it deems undesirable. ${ }^{321}$

The Conference has yet to press its positions on particular changes in the guidelines system before Congress. Taking this next step would elevate the importance of the congressional oversight function and no longer concede the de facto final word on guideline changes to the Commission.

The Judicial Conference should assert itself as a coequal with the Commission in presenting guideline issues to Congress. Each year it should file an assessment of the guidelines system and a critique of pending amendments. It should not assume that Congress is aware of positions that the Conference takes before the Commission. The Conierence should directly request the Judiciary Committees of the Senate and House to convene hearings to receive testimony regarding the guidelines system, the loss of confidence in it by courts and practitioners, and the avoidance and manipulation that rigid and severe guidelines are producing.

\section{The Sentencing Commission}

The Commission should reverse its policy of the first five years and begin openly responding to the courts. It should cooperatively develop sentencing guidance with the judiciary, rather than unilaterally prescribe guidelines for the judiciary. It should also seek to incorporate, to the extent consistent with the SRA, common law principles traditionally followed by sentencing judges. ${ }^{322}$ The Commission should glean principles from the statements of reasons transmitted by district judges under 28 U.S.C. $\S 994(w),{ }^{323}$ as well as from informal suggestions from the judiciary.

The Commission should recognize that rules resisted by the multi-discretionary process of district courts can achieve neither the compliance nor the respect that Congress envisioned. The working hypothesis in the future should

321. See Becker Statement, supra note 10; Cohn \& Broderick, supra note 10; Judge Charles P. Kocoras, N.D. Ill., Statement to the U.S. Sentencing Comm'n on belralf of the Judicial Conference Comm. on Criminal Law and Probation Admin. (Mar. 1990), in 2 FED. SENTENCING REP. 240 (1990); Public Hearing, supra note 10 , at 287.

322. For a description of a common law sentencing regime, see WHEELER ET AL., supra note 29.

323. There has been disappointingly little response by the Commission to this potentially valuable source of judicial principles and suggestions. Section $994(w)$ requires the Commission to submit at least annually a report to Congress based on individual case reports, but the description of judicial input and the Commission's use of it (in annual reports) remains very slim. This might make a fruitful area of research for scholars with access to the Commission's Washington office. 
be that if judges are given sensible principles to guide sentencing away from unwarranted disparity and disproportionality, they can be trusted to sentence consistently.

The Commission might begin by modifying those guidelines and policy statements that most aggravate the federal district courts: the "not ordinarily relevant" policy statements in chapter $5 \mathrm{H} ;{ }^{324}$ the requirement of a government motion before a judge may consider a substantial assistance departure in nonmandatory penalty cases under 28 U.S.C. $\$ 994(n)$ and section $5 \mathrm{~K} 1.1$; $^{325}$ the relevant conduct guideline, section $1 \mathrm{~B} 1.3$, which is causing so much confusion and sentence inflation in guilty plea cases; ${ }^{326}$ and the presumption that first offenders must go to prison despite the provisions of 28 U.S.C. $\S 994(j) .{ }^{327}$ It should substantially simplify its forty-three-level guideline matrix. The Commission should also begin complying with 28 U.S.C. $\$ 994(\mathrm{~g})$, tailoring its guidelines to the capacity of federal prisons, and simultaneously embarking on a program to authorize intermediate punishments for nondangerous offenders. ${ }^{328}$

Accompanying the reduction of guideline severity and the relaxation of guideline complexity should be a Commission-sponsored inquiry into the nature and causes of system discontent with the guidelines. To ensure respect for the results of the study, the research team might be jointly appointed by the Commission and the Federal Judicial Center. Pending the outcome of the study, the Commission should heed earlier recommendations of the Judicial Conference to slow down the guideline amendment process.

The goal of these suggestions is to gain the confidence of judges and practitioners in a guidance system to which they have substantially contributed and whose policies, standards, and flexibility they are likely to respect.

\section{The Congress}

Whenever notified that the Commission and the Judicial Conference of the United States are at odds about guideline policy, the Judiciary Committees of Congress should give these two institutions a full hearing. Congress should acknowledge the Judicial Conference as at least an equal with the Commission in presenting sentencing issues for legislative consideration.

The other major item on the congressional sentencing agenda should be the removal or modification of mandatory penalty laws, which have led to dismay,

324. See supra Part III.C.3.

325. See supra Part III.C.2.c.

326. Goodwin, supra note 133; see also supra Part III.C.2.d.

327. 28 U.S.C. $\$ 994(j)$ (1988) (citing "general appropriateness of imposing a sentence other than imprisonment" for first offenders).

328. See MORRIS \& TONRY, supra note 69; Helen G. Comothers, The Federal Offender: A Program of Intermediate Punishments, 4 FED. SENTENCING REP. 23 (1991); see also supra notes 107-08, 147-48 and accompanying text. 
disparity, and evasion in the federal courts. The mood of unvarnished cruelty that those penalties symbolize no doubt diminishes the Commission's ability to moderate its guideline penalty structure in accord with the "sufficient, but not greater than necessary" principle of 18 U.S.C. § 3553(a).

The importance of drastically curtailing mandatory penalties was stated well by a congressman from Texas, George Bush, more than twenty years ago:

The bill eliminates mandatory minimum penalties, except for professional criminals. Contrary to what one might imagine, however, this will result in better justice and more appropriate sentences. For one thing, Federal judges are almost unanimously opposed to mandatory minimums, because they remove a great deal of the court's discretion. In the vast majority of cases which reach the sanctioning stage today, the bare minimum sentence is levied-and in some cases, less than the minimum mandatory is given. This is particularly true in cases where addict possessors who sell to support their habits are involved, and a great deal of plea bargaining in this area results. Probations and outright dismissals often result.

Philosophical differences aside, practicality requires a sentence structure which is generally acceptable to the courts, to prosecutors, and to the general public .... 329

Although the author of that statement has gone on to higher office and to other views about mandatory penalties, ${ }^{330}$ his 1970 analysis retains undiminished power today.

\section{CONCLUSION}

Congress gave the United States Sentencing Commission a difficult task to perform and not much time to begin carrying it out. At the same time, Congress began enacting numerous mandatory minimum penalties, a preoccupation that eight years later has cast a depressing shadow over the Commission's task. These rigid statutes are wholly at odds with the sort of principled guidance and permissible individualization of penalties that Congress prescribed in the SRA. The contemporaneous reign of guidelines and mandatory penalties has markedly tilted the Commission's work and reduced the tolerance with which judges might have responded to guidelines alone.

The early reactions by district courts to the guidelines have made it clear that, with respect to a number of significant issues, the Commission elected the wrong policies for federal sentencing reform. While embarking on a mission

329. 116 CONG. REC. H33,314 (daily ed. Sept. 23, 1970) (statement of Rep. George Bush), reprinted in 3 FED. SENTENCING REP. 108 (1990).

330. For example, President Bush's 1992 National Drug Control Strategy calls for "[s]tiff mandatory minimum sentences" for various drug offenses. THE WHITE HOISE, NATIONAL DRUG CONTROL STRATEGY 151 (1992). 
in which other jurisdictions have succeeded, it has rejected wise lessons from their experience. It has opted for rigidity rather than flexibility in its approach, complexity rather than ease of understanding in its guidance, and severity rather than patient observation and research in its stance.

The Commission has taken a significantly less generous approach to public access and lessons from the field than did its forerunner in Minnesota. It has devoted nearly five years to teaching mechanical guidelines to federal probation officers, lawyers, and judges, instead of learning from them how the existing guidelines hamper justice in the field. It has responded to statutory departures under 18 U.S.C. $\S 3553($ b) by suggesting that they evidence noncompliance, and by trying to plug guideline loopholes rather than by listening to the messages judges, and their sentences, were sending.

The Commission has done nothing to constrain prison sentences within prison capacity limits, as the SRA instructed. It has failed to implement the principle of parsimony in punishment that the ALI and ABA began espousing decades ago, and that Congress incorporated in the SRA. It has not followed the example of state and local criminal justice systems that experimented with intermediate punishments in order to avoid unnecessary imprisonment of nondangerous offenders and unnecessary incursions on public funds in an era of financial stringency.

Courts of appeals, divided between allegiance to the guidelines and deference to the district courts, have too often interpreted the guidelines more strictly than Congress required. Appellate decisions have thereby driven many participants in the lower courts to evade the guidelines, resolve sentences by agreement, and avoid review.

Appellate courts have made one especially unwise policy choice not mandated by the statutory language defining the standard for judicial review of Commission action: they have presumed that the Commission gave adequate consideration to nearly all of its sentencing policies and choices, instead of imposing on the Commission the burden of demonstrating in the text of the Guidelines Manual itself the adequacy of consideration. The adequate consideration standard enables courts to ensure that the Commission sufficiently spells out its research and reasoning, and the competing considerations it has weighed, so that judges can decide whether a compelling circumstance, to the degree present in the case before them, falls inside or outside a guideline.

The Commission has sought to carry out an "evolutionary process" by forcing new rules on a discretionary system, rather than by articulating principles that incorporate the wisdom of past cases and trusting that the system will value those principles and follow them. It ought to have heeded the advice of Professors Oaks and Lehman in their landmark study of criminal justice in Chicago: 
The surest way to solve systemic problems is the slowest: to advocate ideals rather than to institute them. Ideals that are absorbed by the participants in, and by the clients of, a system are likely to find expression in the system, and to find expression in ways that do not disrupt the system. The general pressure of ideals is unlikely to be disruptive because the demands of those ideals will be put into effect by people who are subjected to all the pressures of the system. People so placed will probably act only when they can act without sacrificing conflicting goals .... One of the most important reasons why judges are generally limited to the disposition of cases and controversies is that only in a real case is the judge likely to have presented to him the real pressures that must be resolved before action is taken. ${ }^{331}$

Had the Commission better understood the need to go slowly, spent more time learning about judicial and prosecutorial discretion, and less time attacking its critics, it might have created a more workable system. Instead, it has produced growing dissatisfaction by those on the front lines, evidenced by more and more sentencers consciously avoiding the perceived injustice of the guidelines through informal noncompliance. While justice may be served in this way, it is served at the cost of increasing hidden disparity-the very evil the guidelines were intended to cure. Five years is enough time to know that the guidelines are heading in the wrong direction. It is time for the judiciary to prod the Commission and the Congress to get the guidelines back on course.

331. See Dallin H. OAKS \& WarRen LehMaN, A CRIMINAL JUSTICE System AND the INDigent 195 (1968). 